Prepared in cooperation with the NORTH PLATTE NATURAL RESOURCES DISTRICT

\title{
Interaction of Surface Water and Ground Water in the Dutch Flats Area, Western Nebraska, 1995-99
}

Water-Resources Investigations Report 01-4070

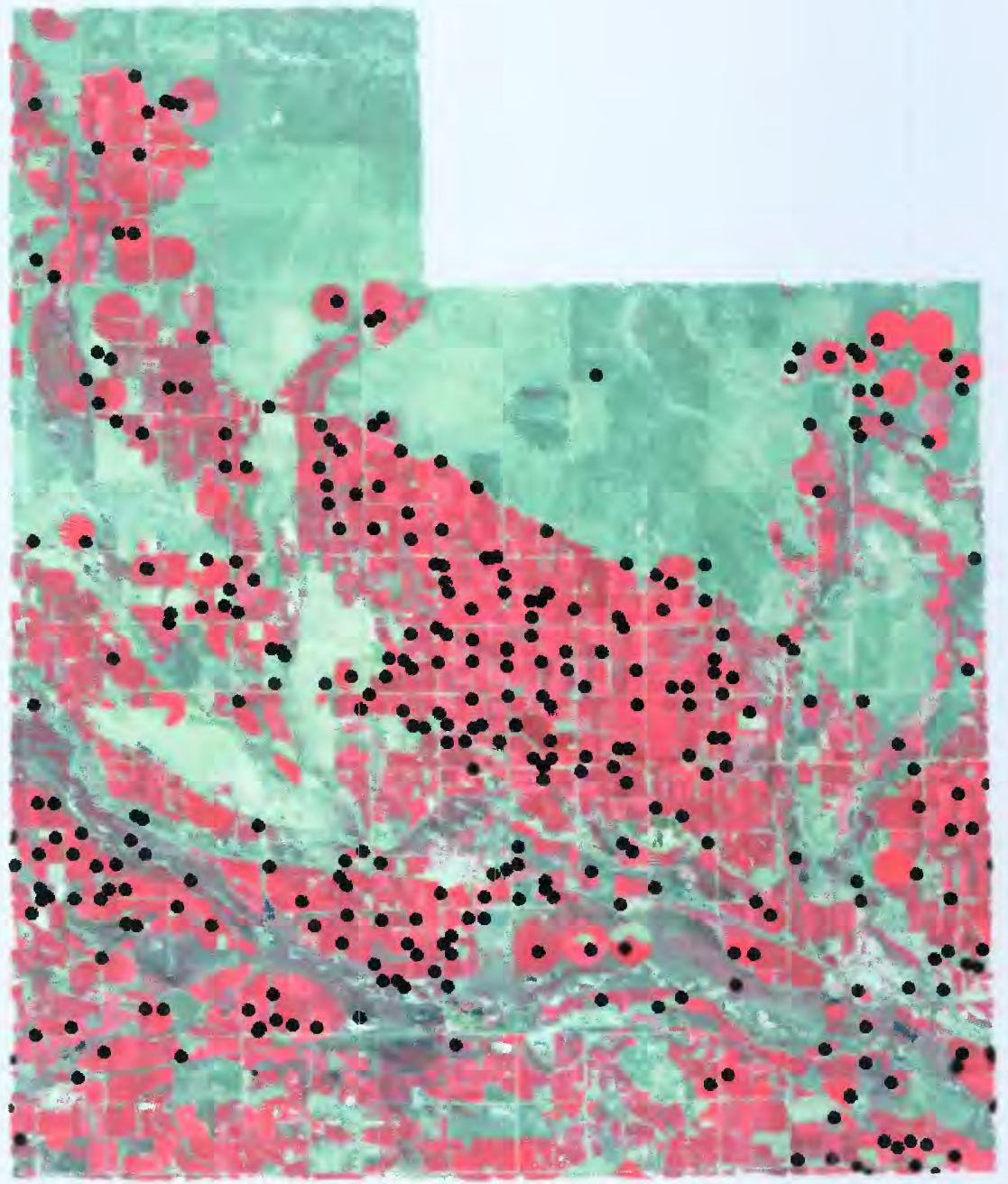


Cover: Landsat Thermal Mapper (TM) image. The false color composite is created by displaying the infrared band with the red color gun, red band with the green color gun, and green band with the blue color gun. Areas that appear red on the image tend to indicate areas of significant vegetation. 


\section{Interaction of Surface Water and Ground Water in the. Dutch Flats Area, Western Nebraska, 1995-99}

By I.M. Verstraeten, G.V. Steele, J.C. Cannia, D.E. Hitch, K.G. Scripter, J.K. Böhlke, T.F. Kraemer, and J.S. Stanton

Water-Resources Investigations Report 01-4070 


\section{U.S. DEPARTMENT OF THE INTERIOR \\ GALE A. NORTON, Secretary}

\section{U.S. GEOLOGICAL SURVEY}

CHARLES G. GROAT, Director

The use of firm, trade, and brand names in this report is for identification purposes only and does not constitute endorsem?nt by the U.S. Geological Survey.

Lincoln, Nebraska: 2001

For additional information write to:

District Chief

U.S. Geological Survey

406 Federal Building

100 Centennial Mall North

Lincoln, NE 68508

Copies of this report can be purchased from:
U.S. Geological Survey
Information Services
Building 810
Box 25286, Federal Center
Denver, CO 80225-0286 


\section{CONTENTS}

Abstract …

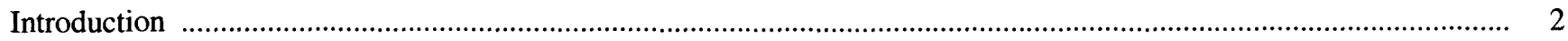

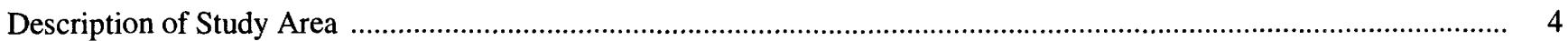

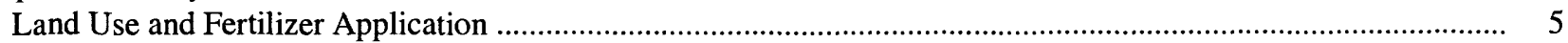

Water Use

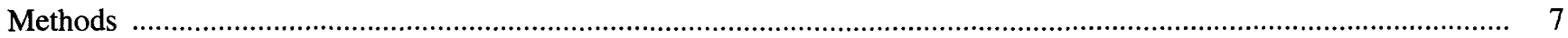

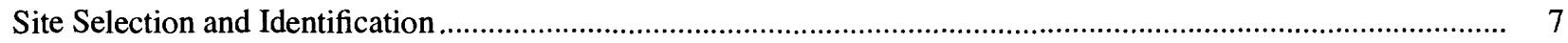

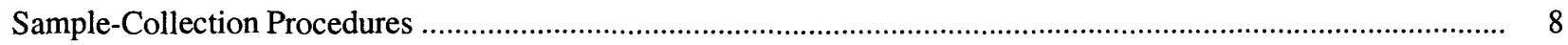

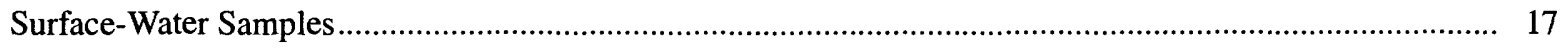

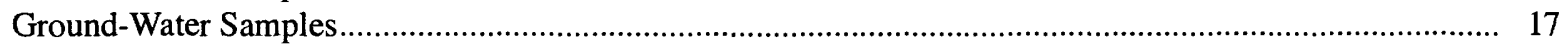

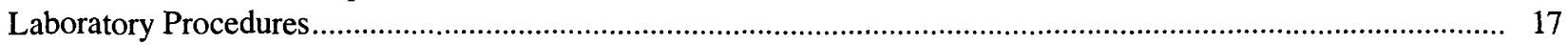

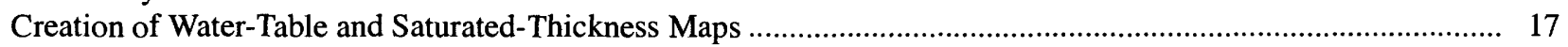

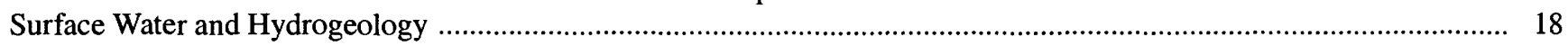

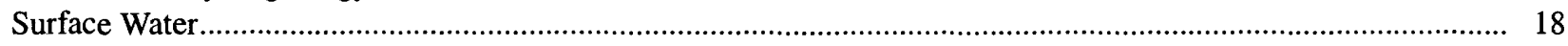

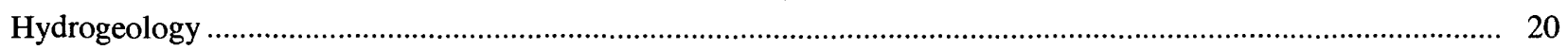

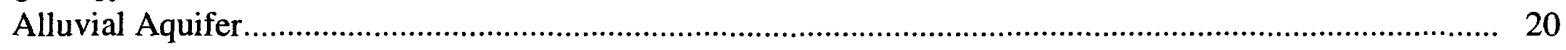

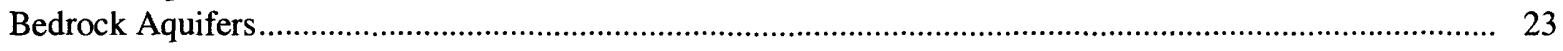

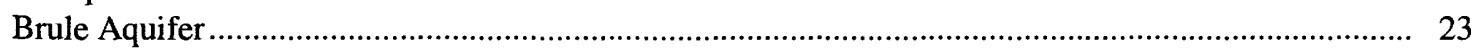

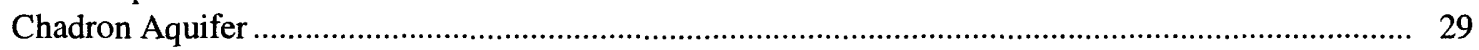

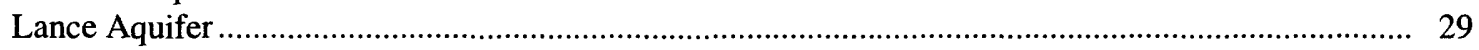

Selected Water-Quality Constituents in Surface and Ground Water ................................................................... 29

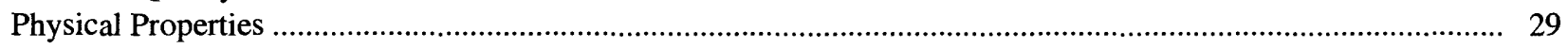

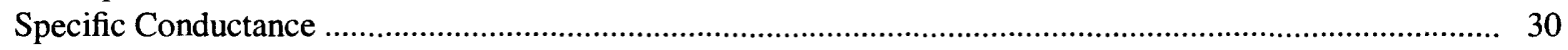

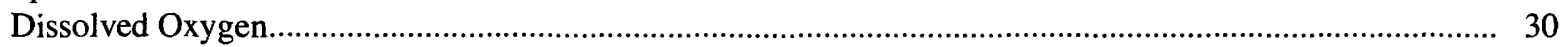

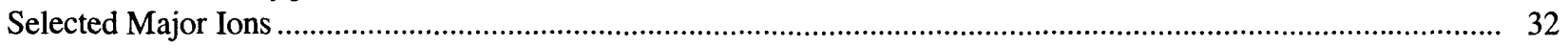

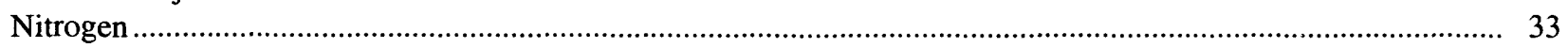

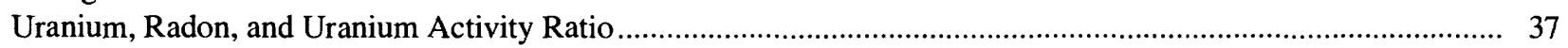

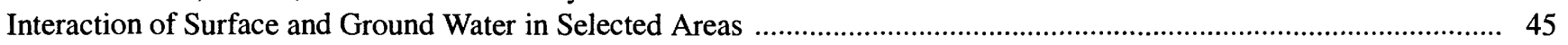

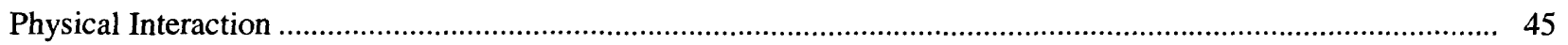

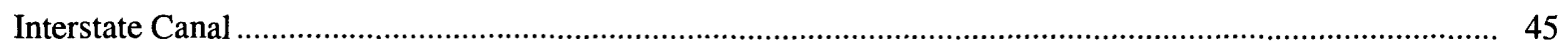

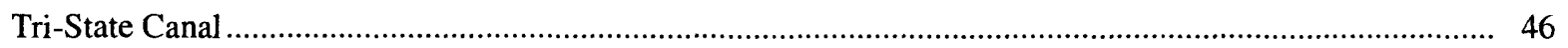

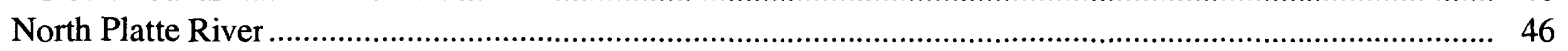

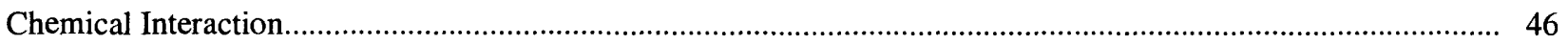

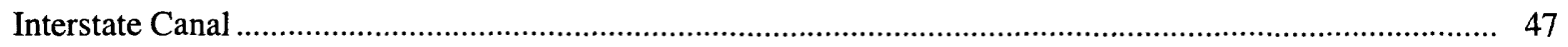

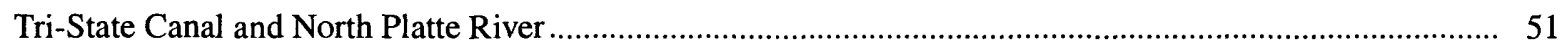

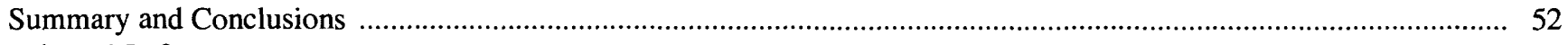

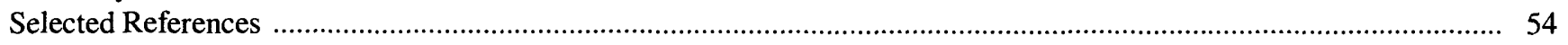

FIGURES

1. Map showing location of the Dutch Flats study area, surface-water sampling sites, and irrigation wells, western Nebraska

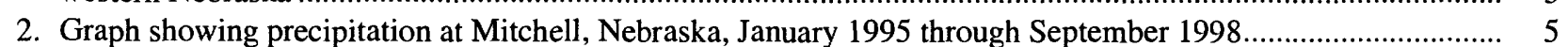

3. Map showing land use in the Dutch Flats study area, 1997 ......................................................................... 6

4. Graph showing fertilized and irrigated acreage and commercial fertilizer use in Scotts Bluff County,

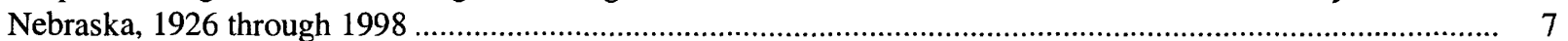

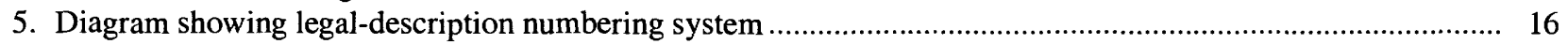


6. Graph showing discharge of North Platte River at Wyoming-Nebraska State line, Horse Creek near Lyman, and Sheep Creek near Morrill, Nebraska, 1995 through 1998

7. Graph showing daily flow duration of North Platte River at Wyoming-Nebraska State line, 1929 throngh 1998

8. Map showing surficial geology and traces of generalized geologic sections, ground-water sampling $\mathrm{s}^{\text {ites, }}$ and test holes, Dutch Flats area .

9. Generalized geologic sections $A-A$ ' through $D-D$ ' showing principal geologic units transected by g "oundwater sampling sites and test holes, Dutch Flats area

. Map showing saturated thickness of alluvial aquifer, Dutch Flats area, summer 1998.

11. Map showing configuration of water-table altitude in alluvial aquifer, Dutch Flats area, summer $199 \varepsilon$.....

12. Graph showing water levels in selected monitoring wells along section $B-B^{\prime}$, Dutch Flats area, May 1995 through September 1998.

13. Maps showing distribution of specific-conductance values in surface water and water from wells comsleted near water table and wells completed in or just above bedrock, Dutch Flats area, summers of 1998 or 1999.

14. Trilinear diagram showing ionic composition of water from selected surface-water and ground-water sampling sites along geologic section $B-B^{\prime}$, Dutch Flats area, summer 1998

15. Maps showing distribution of nitrate concentrations in surface water and water from wells completed near water table and wells completed in or just above bedrock, Dutch Flats area, summers of 1998 and 1929

16. Generalized geologic section $B-B^{\prime}$ showing nitrate concentrations, Dutch Flats area, summer 1998.

17. Graph showing distribution of nitrate concentrations by depth below water table, Dutch Flats area, summer 1998

18. Maps showing distribution of uranium concentrations in surface water and in water from wells comp'ed near water table and wells completed in or just above bedrock, Dutch Flats area, summers of 1998 and $19 ? 9$..........

19. Generalized geologic section $B-B$ ' showing uranium concentrations, Dutch Flats area, summers of 1998 and 1999

20. Maps showing distribution of radon activities in surface water and water from wells completed near water table and wells completed in or just above bedrock, Dutch Flats area, summers of 1998 and 1999.

21. Generalized geologic section $B-B$ 'showing radon activities, Dutch Flats area, summer 1998

22. Maps showing distribution of uranium activity ratios in surface water and water from wells complete 1 near water table and wells completed in or just above bedrock, Dutch Flats area, summers of 1998 and 1929

23. Generalized geologic section $B-B^{\prime}$ 'showing uranium activity ratios, Dutch Flats area, summers of 1098 and 1999

Graphs showing:

24. Comparison of trends in dissolved oxygen, nitrate, and uranium concentrations, and uranium activity ratios and discharge for Interstate Canal, Tri-State Canal, and North Platte River at Morrill and North P'atte River at Wyoming-Nebraska State line, 1995 through 1998.

25. Trends in dissolved oxygen, nitrate, and uranium concentrations, and uranium activity ratios in w7ter from nested wells 1A, 1B, and 1C, Dutch Flats area, 1995 through 1998

26. Trends in dissolved oxygen, nitrate, and uranium concentrations, and uranium activity ratios in water from well 2A-1, and nested wells 2B and 2C, Dutch Flats area, 1995 through 1998.

27. Trends in dissolved oxygen, nitrate, and uranium concentrations, and uranium activity ratios in water from nested wells 1J, 2J, and 1L, Dutch Flats area, 1995 through 1998

28. Trends in specific-conductance values and sulfate concentrations of water samples from Interstate Canal, North Platte River, and nested wells 2B and 1L, Dutch Flats area, 1995 through 1998.

\section{TABLES}

1. Surface-water sampling sites in Dutch Flats area, western Nebraska

2. Information for ground-water sampling sites in Dutch Flats area, western Nebraska .................................... 9

3. Principal hydrogeologic units in Dutch Flats area, western Nebraska .......................................................... 21 


\begin{tabular}{|c|c|c|}
\hline Multiply & By & To obtain \\
\hline \multicolumn{3}{|c|}{ Length } \\
\hline inch (in.) & 2.54 & centimeter \\
\hline foot $(\mathrm{ft})$ & 0.3048 & meter \\
\hline mile (mi) & 1.609 & kilometer \\
\hline \multicolumn{3}{|c|}{ Area } \\
\hline acre & 4,047 & square meter \\
\hline square mile $\left(\mathrm{mi}^{2}\right)$ & 2.590 & square kilometer \\
\hline \multicolumn{3}{|c|}{ Volume } \\
\hline acre-foot (acre-ft) & 1,233 & cubic meter \\
\hline gallon (gal) & 3.785 & liter \\
\hline \multicolumn{3}{|c|}{ Flow rate } \\
\hline cubic foot per second $\left(\mathrm{ft}^{3} / \mathrm{s}\right)$ & 0.02832 & cubic meter per second \\
\hline cubic foot per second per day $\left[\left(\mathrm{ft}^{3} / \mathrm{s}\right) / \mathrm{d}\right]$ & 0.02832 & cubic meter per second per day \\
\hline foot per mile $(\mathrm{ft} / \mathrm{mi})$ & 0.1894 & meter per kilometer \\
\hline gallon per minute (gal/min) & 0.06309 & liter per second \\
\hline inch per year (in/yr) & 2.54 & centimeter per year \\
\hline \multicolumn{3}{|c|}{ Radioactivity } \\
\hline picocurie per liter (pCi/L) & 0.037 & becquerel per liter \\
\hline \multicolumn{3}{|c|}{ Hydraulic conductivity } \\
\hline foot per day $(\mathrm{ft} / \mathrm{d})$ & 0.3048 & meter per day \\
\hline
\end{tabular}

Temperature in degrees Celsius $\left({ }^{\circ} \mathrm{C}\right)$ may be converted to degrees Fahrenheit $\left({ }^{\circ} \mathrm{F}\right)$ as follows:

$$
{ }^{\circ} \mathrm{F}=\left(1.8 \times{ }^{\circ} \mathrm{C}\right)+32 \text {. }
$$

Temperature in degrees Fahrenheit $\left({ }^{\circ} \mathrm{F}\right)$ may be converted to degrees Celsius $\left({ }^{\circ} \mathrm{C}\right)$ as follows:

$$
{ }^{\circ} \mathrm{C}=\left({ }^{\circ} \mathrm{F}-32\right) / 1.8 \text {. }
$$

Sea level: In this report, "sea level" refers to the National Geodetic Vertical Datum of 1929 (NGVD of 1929)—a geodetic datum derived from a general adjustment of the first-order level nets of both the United States and Canada, formerly called Sea Level Datum of 1929.

Altitude, as used in this report, refers to distance above or below sea level.

Specific conductance is given in microsiemens per centimeter at 25 degrees Celsius $\left(\mu \mathrm{S} / \mathrm{cm}\right.$ at $\left.25^{\circ} \mathrm{C}\right)$.

Concentrations of chemical constituents in water are given either in milligrams per liter $(\mathrm{mg} / \mathrm{L})$ or micrograms per liter $(\mu \mathrm{g} / \mathrm{L})$. 


\title{
Interaction of Surface Water and Ground Water in the Dutch Flats Area, Western Nebraska, 1995-99
}

\author{
By I.M. Verstraeten ${ }^{1}$, G.V. Steele ${ }^{1}$, J.C. Cannia ${ }^{2}$, D.E. Hitch ${ }^{3}$, K.G. Scripter ${ }^{2}$, J.K. Böhlke ${ }^{4}$, \\ T.F. Kraemer ${ }^{4}$, and J.S. Stanton ${ }^{1}$
}

\section{Abstract}

A study of the water resources of the Dutch Flats area in western Nebraska was conducted from 1995 through 1999 to describe the surface water and hydrogeology, the spatial distribution of selected water-quality constituents in surface and ground water, and the surface-water/ground-water interaction in selected areas. As part of this effort, 11 surface-water sites and 79 ground-water sites were selected, water levels were measured, and 130 surface-water and 1,960 ground-water samples were collected for chemical analyses.

Recharge to the ground-water system by precipitation is much less than recharge to the ground-water system by infiltration of water seeping from irrigation canals and laterals and by infiltration of water applied to fields for irrigation.

Specific conductance, calcium, magnesium, sulfate, nitrate, and uranium concentrations, and uranium activity ratios varied in space and time and were used in the evaluation of surfacewater/ground-water interaction and determination of ground-water flow. The specific-conductance values in water from the Interstate Canal and in ground water immediately upgradient from the canal were different. However, differences in specific-conductance values between surface and ground water were not as obvious near the TriState Canal and were variable near the North Platte River. Differences in major-ion composi-

\footnotetext{
${ }^{1}$ U.S. Geological Survey, Lincoln, Nebraska.

${ }^{2}$ North Platte Natural Resources District, Gering, Nebraska.

${ }^{3}$ U.S. Geological Survey, North Platte, Nebraska.

${ }^{4}$ U.S. Geological Survey, Reston, Virginia.
}

tions indicated flow paths. Water from the northern alluvial aquifer generally moved from north to south and mixed in part with water from the F rule aquifer. In the southern alluvial aquifer south of the North Platte River, water moved from the southwest to the northeast and mixed in part with older water from the Chadron aquifer.

In ground water, a stratification of nitrate concentrations was detected, with large concentrations in shallow, young water at times exceecing 20 milligrams per liter and smaller concentrations less than 0.05 milligram per liter in deep, old water. The U.S. Environmental Protection Agency Maximum Contaminant Level of 10 milligrams per liter was exceeded in 17 of 116 samples from shallow water in the alluvial aquifer. Denitrification did not seem to be an important process in the alluvial aquifer but may be occurring near the contact with bedrock aquifers.

Uranium concentrations varied from 11 to 31 micrograms per liter in water from the North Platte River at Morrill and were smaller in the river at the State line. Uranium concentrations of as much as $\mathbf{4 4}$ micrograms per liter were detected in water samples from Owl Creek near Lyman. Uranium in water samples from the shallow alluvial aquifer ranged from about 2.0 micrograms per liter north of the Tri-State Canal to as much as 80 micrograms per liter in the southern part of the alluvial aquifer. Seventeen of 121 water sam les from the alluvial aquifer exceeded the U.S. Environmental Protection Agency Maximum Contaminant Level of 30 micrograms per liter for uranium. The largest radon activity was observed in water from the Chadron aquifer. Radon 
activity in excess of 1,000 picocuries per liter often was present in water samples from wells completed in the Brule aquifer. Ninety-four of 117 samples from the alluvial aquifer exceeded the proposed U.S. Environmental Protection Agency Maximum Contaminant Level of 300 picocuries per liter for radon.

Water seeping through the unlined bottoms of canals into the alluvial aquifer caused rises in ground-water levels. The North Platte River generally gained streamflow throughout its reach in the study area. Recharge of ground water by surface water from the canals resulted in temporal changes in the quality of ground water. At the Interstate Canal, surface water appeared to replace ground water in about 1 month in the upper 30 feet of the alluvial aquifer within about 1 mile of the canal. The effect was less pronounced in the rest of the study area. Local indicators of surface-water/ground-water interaction included specific-conductance values, calcium, magnesium, sulfate, nitrate, and uranium concentrations, and uranium activity ratios. When water was flowing through the Interstate Canal, increases in specific-conductance values and sulfate concentrations and decreases in nitrate and uranium concentrations, and uranium activity ratios in the shallow ground water were observed.

Overall, surface-water/ground-water interaction recharged the alluvial aquifer in part and provided relief locally near the canals and laterals through dilution of nitrate concentrations in ground water with canal water. However, at greater distances from the canals and laterals, irrigation with canal water transported nitrogen from the land surface to the ground water.

\section{INTRODUCTION}

During the last 10 years, surface and ground water have become regarded as a single resource (Winter and others, 1998). Human activities commonly affect the distribution of surface and ground water, their interaction, and the quality of the water through, for example, a variety of irrigation practices and addition of fertilizer to the land for agricultural purposes. It has been demonstrated that contaminated aquifers discharging to streams can degrade surface-water quality and that streams discharging to ground water can degrade ground-water quality, especially when induced infiltration occurs (Verstraeten and others, 1999). Managers making decisions requiring withdrawals of surface or ground water and their addition to the land surface need to consider the extent to which different pumping conditions affect water availability both or the surface and in the ground (Alley and others, 1999) and the extent to which addition of fertilizer to the land can contaminate water. With knowledge of the available water resources, appropriate management approaches can be used to satisfy water demand and sustain water quality.

The hyporheic zone is the area where stream water flows through short segments of the adjacent streambed (Winter and others, 1998). The zone can vary greatly in time and space. Because surfacewater/ground-water interaction has been d:fficult to quantify, historically these interactions generally have not been considered in Nebraska water-management policies. In 1996, the Nebraska legislature recognized this interaction and promulgated a law acknowledging its existence (State of Nebraska, 1998).

Surface-water/ground-water interacticn is an important aspect of the hydrology of the $\mathrm{L}$ 'tch Flats area, a locally prominent terrain feature in Scotts Bluff and Sioux Counties in the western part of the North Platte Natural Resources District (NRD) in Nebraska (fig. 1). Ground-water-quality investigations done in the North Platte NRD include those by Wenzel and others (1946), Durum (1950), Rainwater (1956), the Conservation and Survey Division (1980a, b), and Verstraeten and others (1995). Surface-water quality in the North Platte NRD was studied by Steele and Cannia (1997) and Druliner and others (1999). The authors of these water-quality studies suggested that large concentrations of nitrate are present in ground water but are not present in surface water. They also suggested that, in parts of the Dutch Flats area, large concentrations of uranium, radon, and gro's alpha are present. Exceedances of U.S. Environmental Protection Agency (USEPA) Maximum Contaminant Levels (MCLs) of nitrate and uranium were found. Concentrations of uranium in places and at times exceeded $30 \mu \mathrm{g} / \mathrm{L}$ in the North Platte River and nearby canals and drains. Babcock and Visher (1951) reported that water from the canals sometimes seeps into the ground and provides a temporary increase in local recharge rates, potentially affecting the quality of the ground water. 


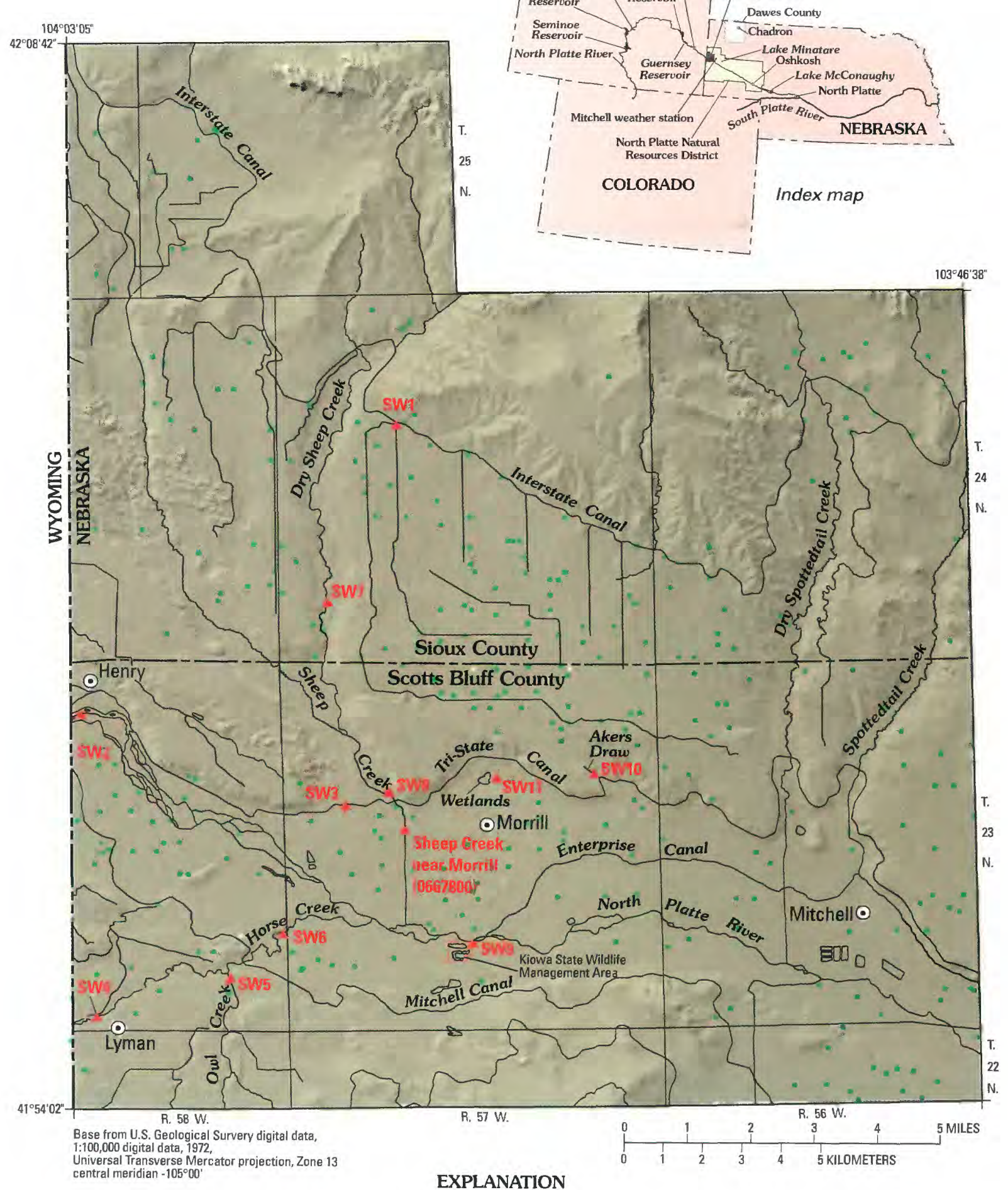

$$
\begin{aligned}
& \mathrm{SW5} \triangle \text { Surface-water sampling site and map index number } \\
& \text { - Irrigation well (1988) }
\end{aligned}
$$

Figure 1. Location of the Dutch Flats study area, surface-water sampling sites, and irrigation wells, western Nebraska. 
It is important for water managers to evaluate how surface and ground water interact because each hydrologic component affects the other. To make a reliable evaluation of the water resources in the Dutch Flats area, more information was needed about the quantity and quality of surface and ground water and their interaction. A study was conducted from 1995 through 1999 by the U.S. Geological Survey (USGS), in cooperation with North Platte NRD, to characterize surface-water/ground-water interaction and the potential effect of seepage from canals on ground-water quantity and quality in the Dutch Flats area. The specific objectives of the study were to describe:

- Surface water and hydrogeology,

- Spatial distribution of selected water-quality constituents in surface and ground water, and

- Surface-water/ground-water interaction in selected areas.

The Dutch Flats forms the majority of the study area. Areas north of the Interstate Canal and south of the North Platte River surrounding the actual flats also were included in the study area (fig. 1).

The purpose of this report is to present the interpretive results of the study. The analytical data from the study are presented in Boohar and Walczyk (1997, 1998), Boohar (2000), and Verstraeten and others (in press).

The authors thank the landowners for permission to construct wells and collect samples on their property. The authors also thank Sonja Sebree, Keith Kollasch, and Aaron Carnes of the USGS for their contributions with geographic information systems (GIS) and creation of figures included in the report, and John Miller of the USGS for his dedication during sampling. Thanks also are extended to Jackie Rick of the North Platte NRD for completion of required forms and creation of data tables during this study. Thanks also are extended to the Nebraska Department of Environmental Quality and the USEPA for their support of the study.

\section{DESCRIPTION OF STUDY AREA}

The study area is a $212-\mathrm{mi}^{2}$ area in the western part of the North Platte NRD, western Nebraska (fig. 1). The Dutch Flats area is in southwestern Sioux County and northwestern Scotts Bluff County in the North Platte River Valley. The study area is characterized by bottomland, a series of terraces with flat upland areas, and footslopes north of the North
Platte River, and bottomland and footslopes south of the North Platte River. Towns in the study area are Henry, Lyman, Morrill, and Mitchell, with a total population of about 3,300. Mitchell has the largest population, about 1,750 residents (Clerk of the Legislature, 1999).

The Dutch Flats area has a semiarid climate with a diverse temperature range, which is characteristic of mid-latitude locations. The mean daily maximum temperature is $62.8^{\circ} \mathrm{F}$, and the mean daily minimum temperature is $34.1^{\circ} \mathrm{F}$. The average annual temperature of the study area in 1997 was $48.0^{\circ} \mathrm{F}$, with the highest average temperature in July $\left(72.4^{\circ} \mathrm{F}\right)$ and the lowest in January $\left(24.8^{\circ} \mathrm{F}\right)$ (M.D. Werner, High Plains Climate Center, University of Nebraska-Lincoln, written commun., 1998). The largest amounts of precipitation generally result from thunderstorms during the months of May and July (fig. 2). The mean annual precipitation at Mitchell (station 5590) was 13.6 in. from 1909 to 1999 (National Oceanic and Atmospheric Administration, 1998). Snowfall generally occurs between October and April. The mean annual snowfall received at the Mitchell station was $16.8 \mathrm{in}$. and is based on data collected from 1906 through 1997 . The maximum monthly snowfall received at Mitchell in 1996 was 13 in. Evaporation generally is variable, with most evaporation occurring during the hot and dry summer months (23 in. during the growing season) (Benham, 1998). The mean annual evaporation at this station was 45 in. from 1949 through 1994 (National Oceanic and Atmospheric Administration, 1994).

Soils primarily are formed from eolian sand, alluvial deposits, or weathered siltstone and mudstone. Soils on the upland, terraces, and footslopes near the surface mainly consist of silt loam and sandy loam. The subsoils in these areas consist of silt loam to fine sand. The soils on the upland are well developed and deep. They are generally well to excessively well drained and have highly variable slopes (Yost and others, 1968).

Soils on the bottomland consist of loam to fine sandy loam near the surface. The bottomland has poorly to well-developed soils, which generally are poorly to somewhat poorly drained, are nearly level, with 0 to 3 percent slopes, and have 0.5 to about 3.0 percent organic matter. The subsoil generally consists of clay, silt, or sand and gravel (Yost and others, 1968). 


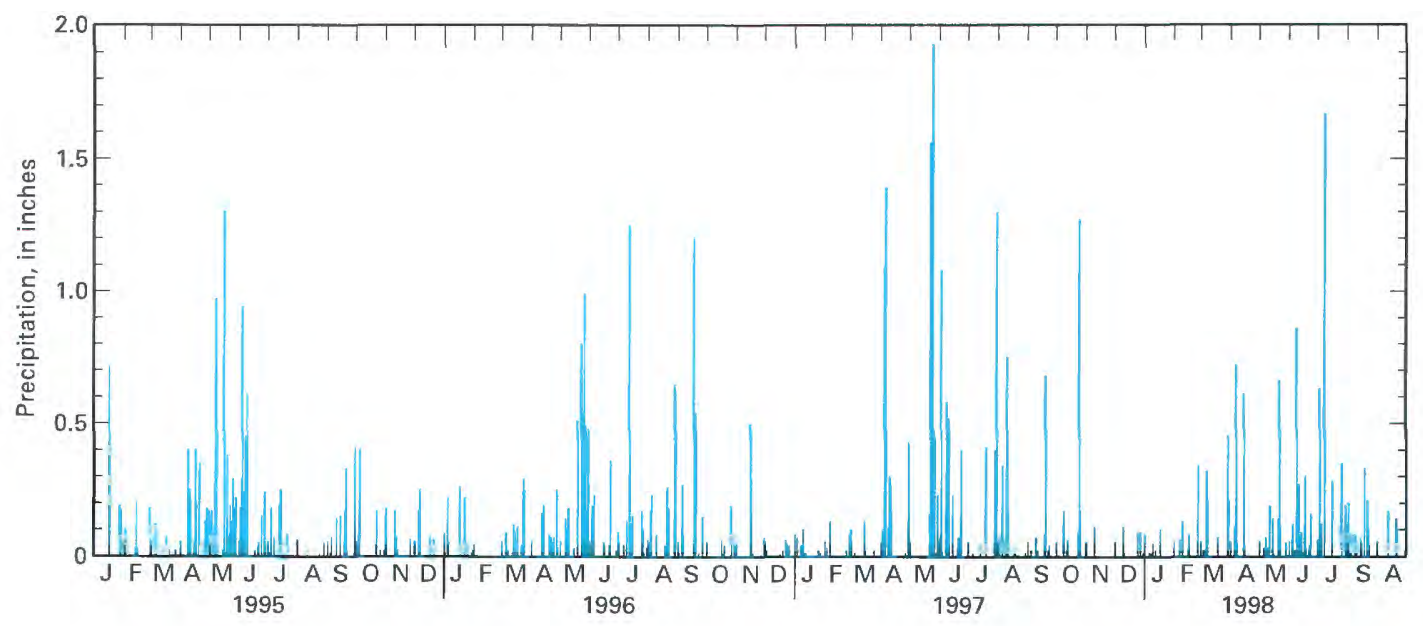

Figure 2. Precipitation at Mitchell, Nebraska (station 5590), January 1995 through September 1998. Data from National Oceanic and Atmospheric Administration (1998).

\section{Land Use and Fertilizer Application}

Agriculture is the primary land use in the study area (fig. 3). Major crops raised in the area are corn, dry beans, sugar beets, and alfalfa. A large part of the study area consists of rangeland. Land uses other than for agriculture include urban, light industry, recreation, a wildlife refuge, and infrastructure. Cattle and hog operations are in the area, as well as a small exotic-game farm. Light industry in the area consists of a sugar-beet processing plant in Mitchell, Nebraska, and a dry-bean processing and distributing plant in Morrill, Nebraska. South of Morrill is the Kiowa State Wildlife Management Area, which provides public hunting and educational activities. Other recreational activities in the area include fishing, bicycling, walking, hiking, and canoeing.

Application of fertilizers, mostly in the form of anhydrous ammonia or manure, has increased gradually over time with about a 15 -fold increase in commercial fertilizer nitrogen use from 1950 to 1994 in Scotts Bluff County (fig. 4). In the study area, fertilizer mainly is applied to corn, dry beans, and sugar beets (fig. 4).

\section{Water Use}

Crops mainly are irrigated by surface water supplied by three major canal systems and laterals (fig. 1). Laterals are large unlined ditches that transport water from the canals to the cropped fields. The Interstate
Canal, also known as the Pathfinder Canal, supplies water for 33,000 acres (Kevin Adams, Farmers Irrigation District, oral commun., 1999). The Tri-State Canal, also known as the Farmers Canal, supplies water for about 3,600 acres. The Mitchell Canal, in the southern part of the study area, supplies water for about 6,600 acres. A total of about 43,200 acres are irrigated from these canals. The Enterprise Canal supplies water for land outside the study area. Crops also are irrigated using ground water; about 14 percent of all the water used for irrigation in Scotts Bluff County in 1995 was supplied by irrigation wells (fig. 1). On the basis of Landsat thematic imagery, the estimated irrigated area in 1997 was between 41,000 and 54,500 acres or between 31 and 41 percent of the land in the study area (Brian Fisher, U.S. Geological Survey, written commun., 1999).

Water use for irrigation in Scotts Bluff County in 1985 was 318,300 acre-ft with a seasonal (June through September) application of 17.7 in. per irrigated acre in a season (Steele, 1988), which is 4 in. more than the mean annual precipitation of $13.6 \mathrm{in} / \mathrm{yr}$. The seasonal irrigation requirement to grow corn has been estimated at $14.2 \mathrm{in}$. in a sandy loam soil in western Nebraska (Benham, 1998). In 1985, surface water contributed 273,600 acre- $\mathrm{ft}$ of the 318,300 acre-ft total, or about 86 percent of all the water applied. Amounts of surface and ground water used for agricultural purposes are dependent upon the precipitation and temperatures during a growing season. Municipalities and selected industries rely mainly on ground water. 


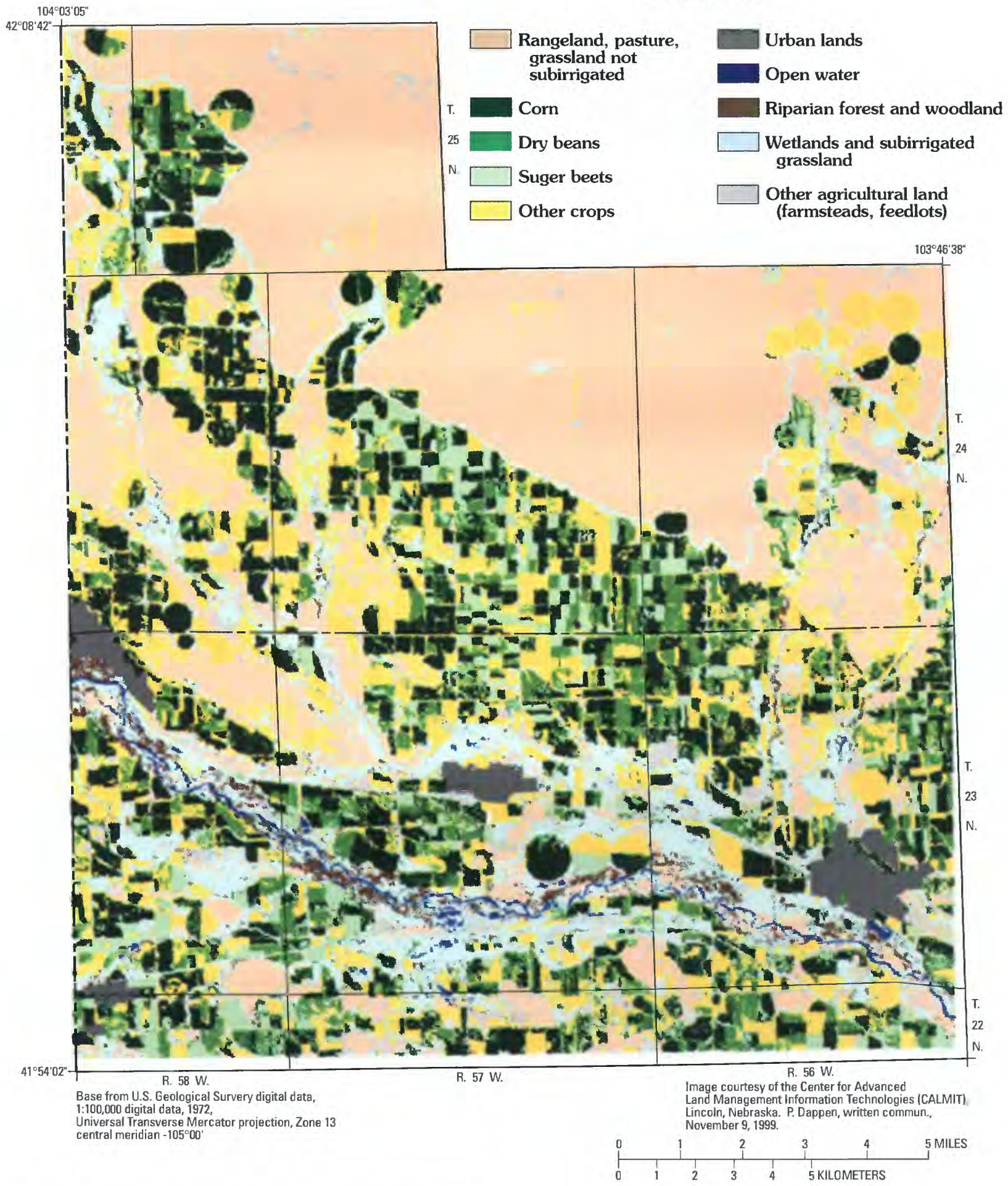

Figure 3. Land use in the Dutch Flats study area, 1997. 


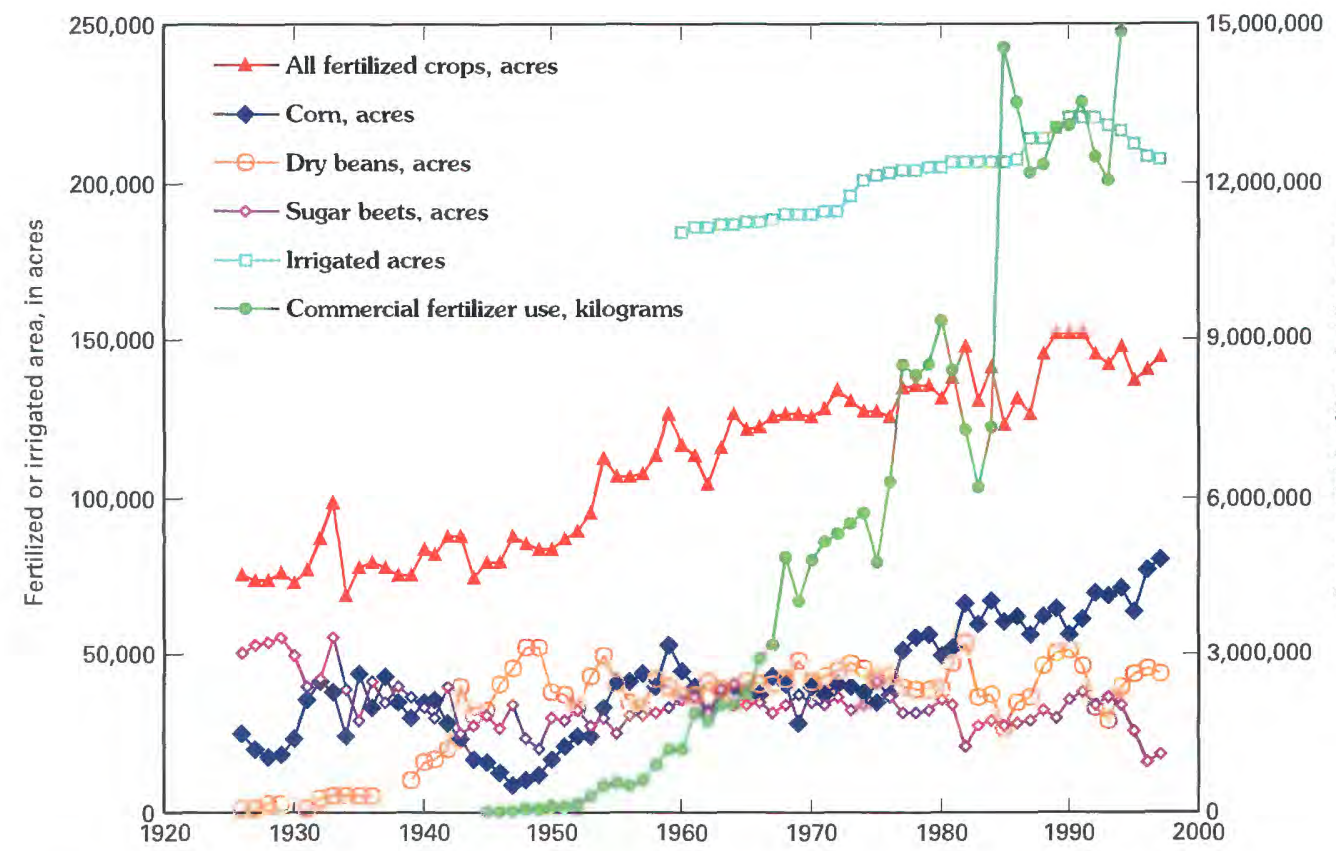

Figure 4. Fertilized and irrigated acreage and commercial fertilizer use in Scotts Bluff County, Nebraska, 1926 through 1998. Acreage data from Nebraska Department of Agriculture (1998). Fertilizer use data from Battaglin and Goolsby (1995).
Four different methods of ground-water site identification were used in this report (table 2).

Sites for ground-water monitoring wells installed for this study were selected to produce parallel transects of semilinear lines running approximately $0.5 \mathrm{mi}$ apart from the Interstate Canal to about 2 to $3 \mathrm{mi}$ south of the North Platte River and to allow easy access. Multiple wells at a site are referred to as "nested wells" in this report; a single well at a site or one of the wells at a nested well site is referred to as a "well."

\section{METHODS}

\section{Site Selection and Identification}

Eleven surface-water sampling sites were selected for this study because they represent the major hydrologic features in the Dutch Flats area (fig. 1; table 1). One wetland site north of the North Platte River was included to evaluate seepage along the Tri-State Canal. One spring, Akers Draw, also was included to evaluate ground-water seepage from the upland terrace. Water in the Interstate Canal is taken from the North Platte River about $50 \mathrm{mi}$ upstream in Wyoming. Additional information about site selection is presented in Verstraeten and others (in press).

For identification of surface-water sampling sites, the first identifier is the USGS official site name (table 1). The second identifier, an eight digit surfacewater USGS identification number, is assigned in a downstream direction along the main stream. The first two digits " 06 " of the identification number represent the major river basin, the Missouri River Basin. However, because wetlands (site SW11) are not a flowing stream, they were identified in a fashion similar to a ground-water site as described later in this section.
Initially, three well transects were installed in a northsouth direction near the center of the study area. Sets of nested wells in a transect are about $1 \mathrm{mi}$ apart. Two sites (wells 2A and 2E) are upgradient of the Interstate Canal; all other sites are in or near areas with active surface-water irrigation, downgradient of the Interstate Canal. Additional nested wells were installed at approximately 2-mi intervals in the study area.

The first site-identification method, the well identification number, is associated with the transect number for the wells. Each well in a transect was given a three- or four-character identification-number, letter, number format. The first number assigned was based on the transect number in which the well was located - first transect (1), second transect (2), and so forth. With some exceptions, the letter sequence was assigned in a manner that designated wells farthest north as A, then proceeding southward to B, C, and so forth. Terminal numbers were assigned to monitoring wells in a nest (such as $1 \mathrm{~A}-1,1 \mathrm{~A}-2$, and $1 \mathrm{~A}-3$ ) and were based on relative well depth-deepest-1, screened in or just above bedrock; intermediate-2 (or shallowest for a two-well nest); and shallowest-3, screened near the water table (for a three-well nest). Locations containing a single monitoring well were assigned a single terminal number (such as $1 \mathrm{~F}-1$ ) or no terminal number (5D). 
Table 1. Surface-water sampling sites in Dutch Flats area, western Nebraska

\begin{tabular}{|c|c|c|c|c|}
\hline $\begin{array}{l}\text { Map index } \\
\text { number } \\
\text { (fig. 1) }\end{array}$ & Surface-water sampling site name & $\begin{array}{l}\text { U.S. Geological } \\
\text { Survey identification } \\
\text { number }\end{array}$ & $\begin{array}{l}\text { Latitude and } \\
\text { longitude }\end{array}$ & $\begin{array}{c}\text { Land- } \\
\text { surface } \\
\text { altitude } \\
\text { (feet above } \\
\text { sea level) }\end{array}$ \\
\hline SW1 & Interstate Canal 6 miles northwest of Morrill, Nebr. & 06656630 & 4203261035706 & 4,206 \\
\hline SW2 & North Platte River at Wyoming-Nebraska State line & 06674500 & 4159251040257 & 4,020 \\
\hline SW3 & Tri-State Canal 2 miles west of Morrill, Nebr. & 06675100 & 4158081035804 & 4,013 \\
\hline SW4 & $\begin{array}{l}\text { Horse Creek } 0.5 \text { mile downstream of } \\
\text { Wyoming-Nebraska State line }\end{array}$ & 06677120 & 4155121040240 & 4,040 \\
\hline SW5 & Owl Creek near Lyman, Nebr. ${ }^{1}$ & 06677300 & 4155481040017 & 4,020 \\
\hline SW6 & Horse Creek near Lyman, Nebr. & 06677500 & 4156211035913 & 3,992 \\
\hline SW7 & Dry Sheep Creek near Morrill, Nebr. & 06677985 & 4200581035823 & 4,060 \\
\hline SW8 & $\begin{array}{l}\text { Sheep Creek north of Tri-State Canal, } \\
\text { near Morrill, Nebr. }\end{array}$ & 06677995 & 4158141035714 & 4,008 \\
\hline SW9 & North Platte River at Morrill, Nebr. & 06678500 & 4156121035544 & 3,978 \\
\hline SW10 & Akers Draw near Morrill, Nebr. & 06678610 & 4158331035329 & 4,010 \\
\hline SW11 & Wetlands 0.75 mile north of Morrill, Nebr. & 415830103551701 & 4158301035517 & 3,980 \\
\hline
\end{tabular}

The second site-identification method uses the unique USGS site identification number, which is a 15-character number that contains no blanks or alphabetic characters and generally is used as an internal control number. Although the site identification number was formed initially from a latitude and longitude, the number is a numeric identifier and has no locational significance (Mathey, 1990, p. 2-10). Wells with first 13 characters of the site identification number in common are distinguished by adding a sequential digit to the number. Sequential numbers are assigned by order of inventory.

The third site-identification method, the legal description, is based on the land subdivisions from the U.S. Bureau of Land Management's (BLM) survey of Nebraska. The number preceding N (north) indicates the township or tier, the number preceding W (west) indicates the range, and the number preceding the terminal letters indicates the section in which the well is located. The terminal letters, designated A, B, C, and $\mathrm{D}$, denote the quarter section, the quarter-quarter section, the quarter-quarter-quarter section, and the quarter-quarter-quarter-quarter section. The designation is given in a counterclockwise direction beginning with "A" in the northeast corner of each subdivision. Like the USGS site identification number, two or more wells are distinguished further by adding a sequential digit to the well number, assigned by order of inventory. For example, 24N 57W 15 CBBD1 (fig. 5) would be in township 24 north, range 57 west, section 15 , quarter section $\mathrm{C}$, quarter-quarter section $\mathrm{B}$, quarterquarter-quarter section $\mathrm{B}$, and quarter-quarter-quarterquarter section $\mathrm{D}$, inventory sequence 1 .

The fourth site-identification method is the well registration number that is assigned by the Nebraska Department of Natural Resources (for example, G-085442).

\section{Sample-Collection Procedures}

Water samples were collected following USGS guidelines to ensure the collection of representative samples. Physical properties were measured onsite and included specific conductance, $\mathrm{pH}$, temperature, and dissolved oxygen. In the latter part of August and the beginning of September 1998, when more detailed analysis of water was done along transect $B-B^{\prime}$, alkalinity also was measured. Samples to be analyzed for organic carbon, major ions, nitrogen, dissolved gases, uranium concentrations, radon activities, and uranium activity ratios were collected, preserved, and transported in accordance with the methods described by Pritt and Jones (1990), Wells and others (1990), and Verstraeten and others $(1995,1999)$. 


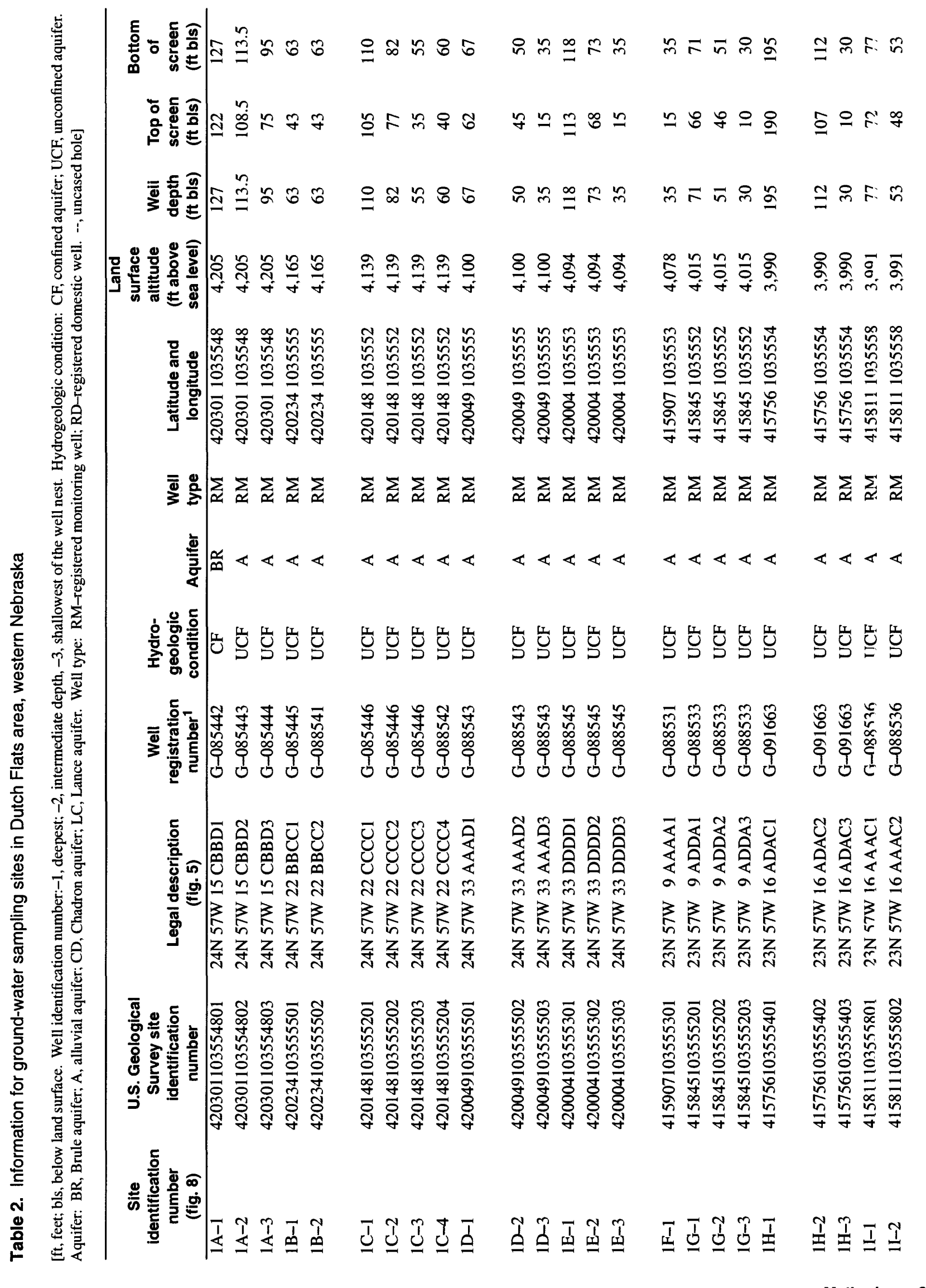




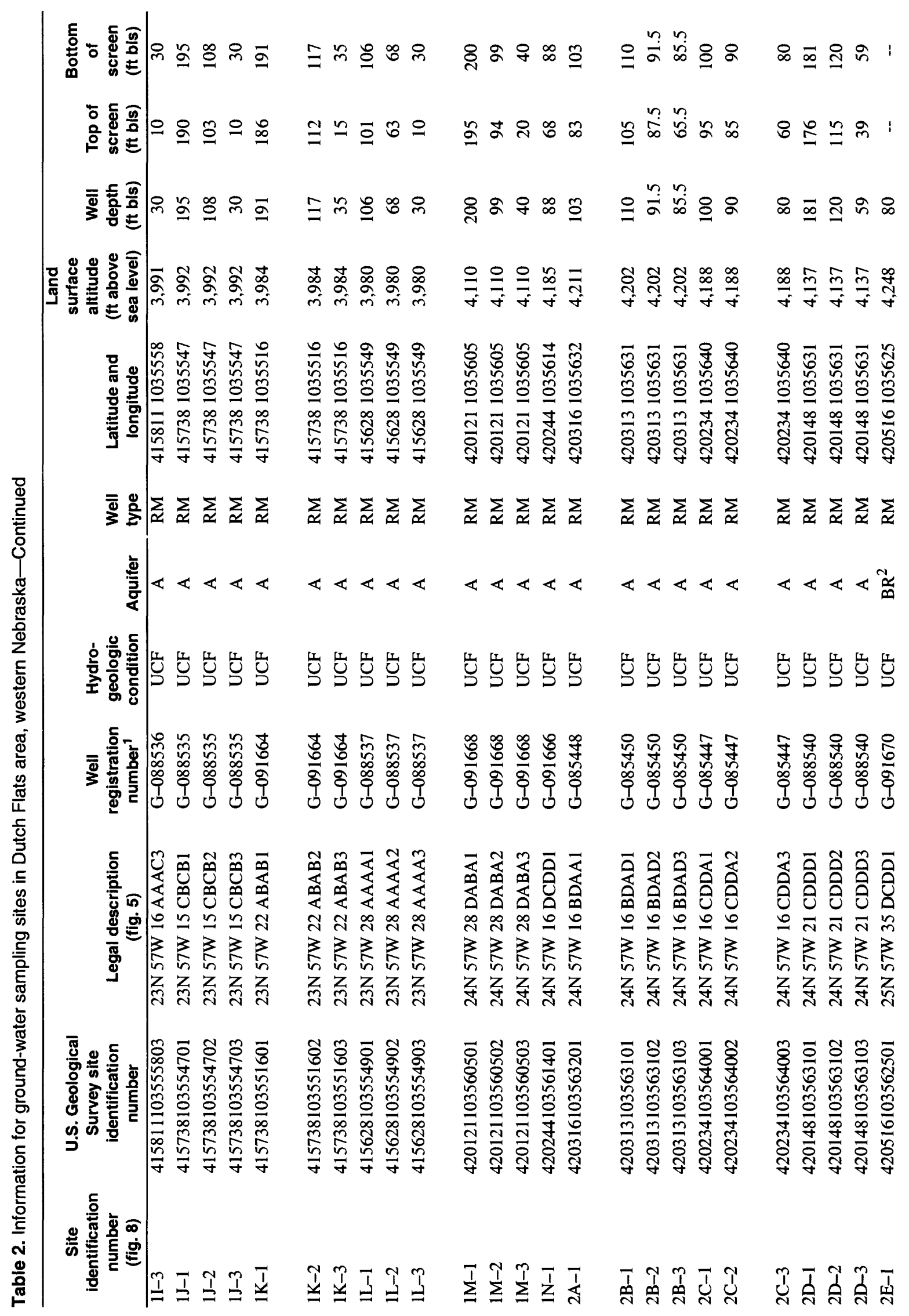

10 Interaction of Surface Water and Ground Water in the Dutch Flats Area, Western Nebraska, 1995-99 


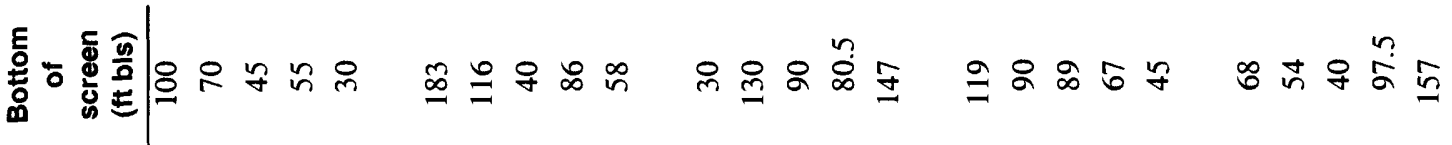

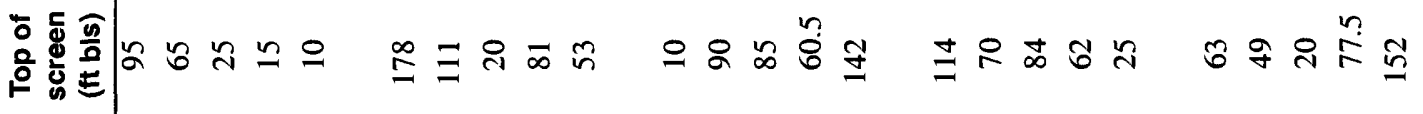

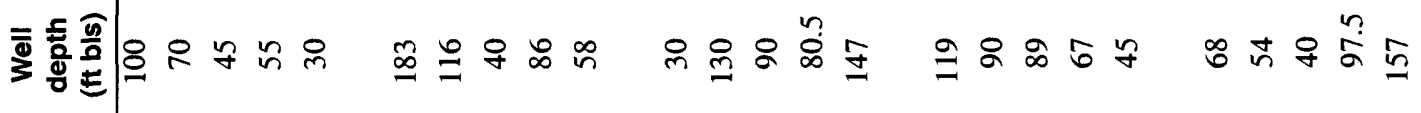

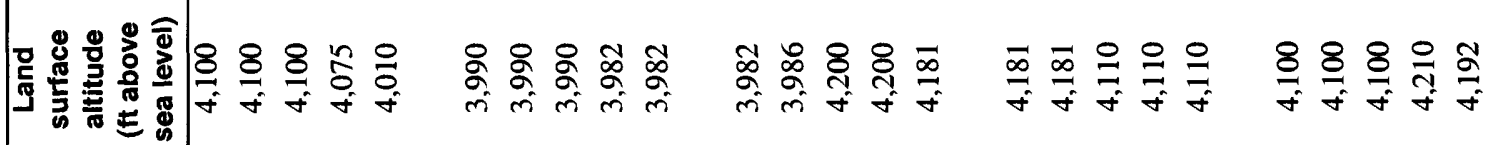

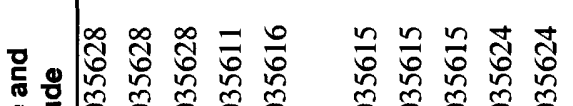

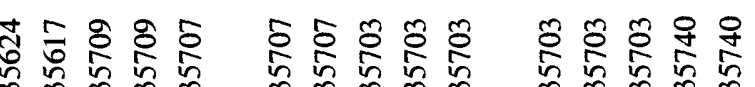

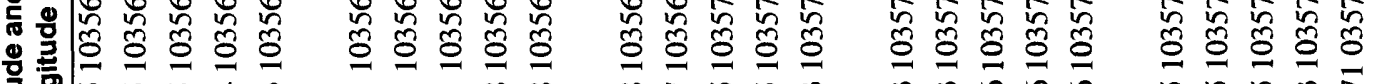

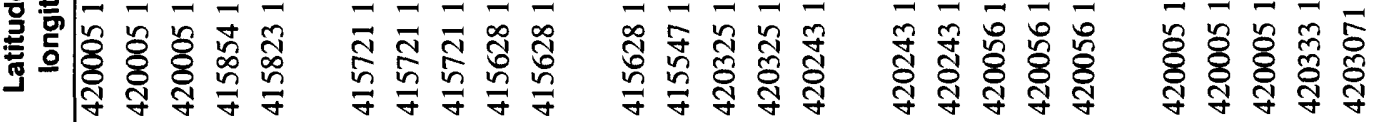

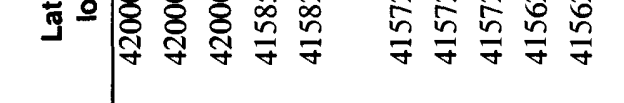

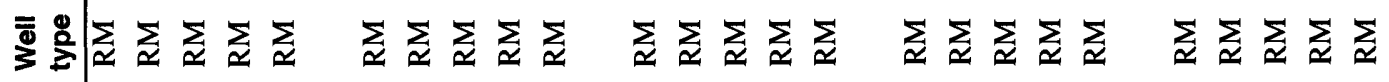

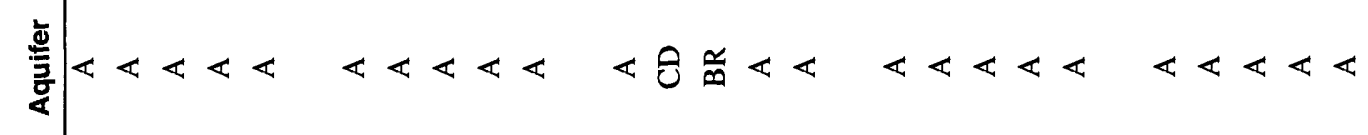

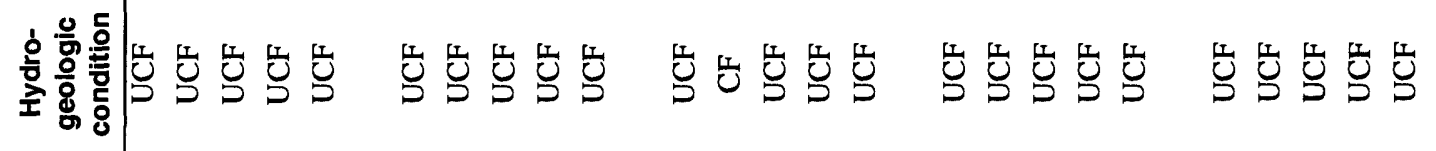

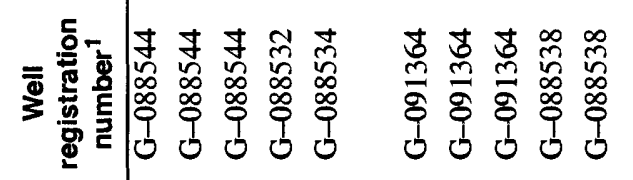

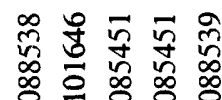

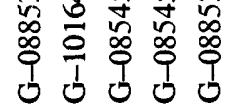

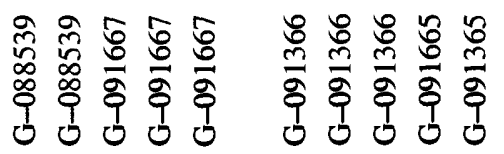

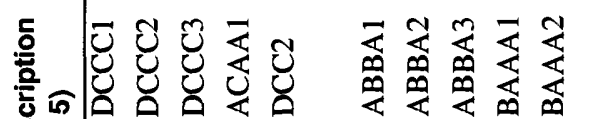
do

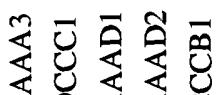

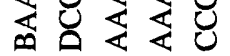
i 交交交交交 令交令令

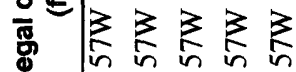

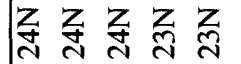

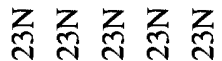

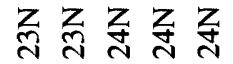
记芑导记 으은

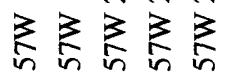
染染染染

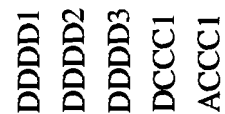
तल

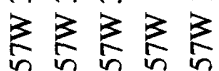

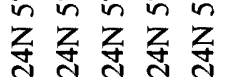

흉융ㅎㅇ 휸 ๙ิ응ㅇㅇ

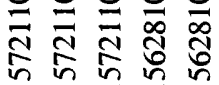

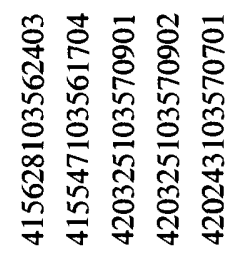

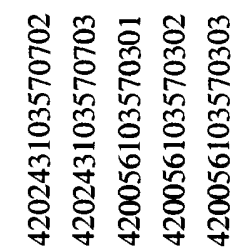

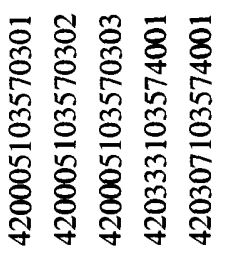

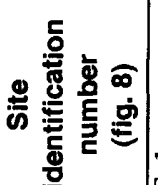

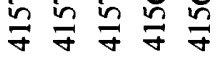

(n)




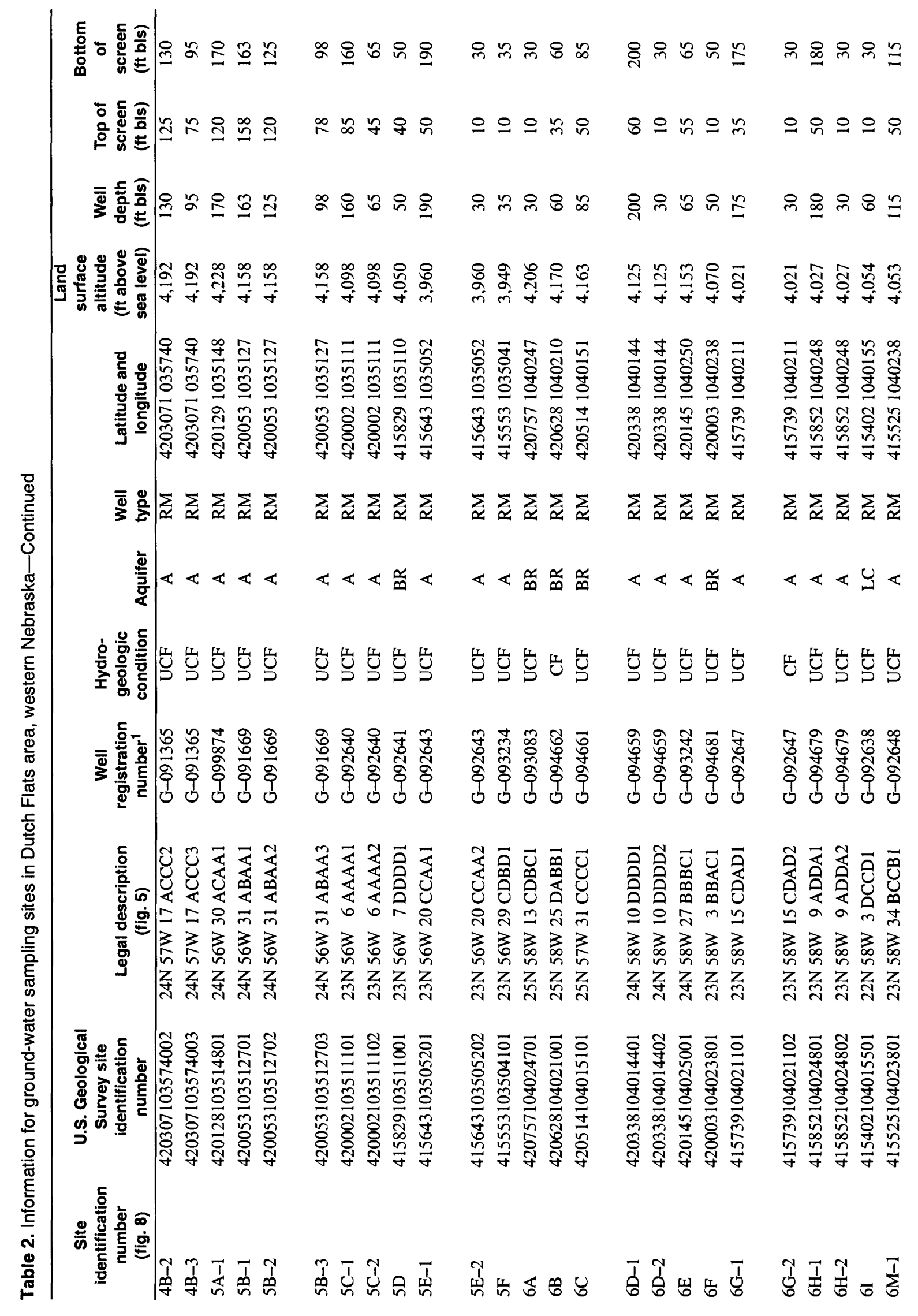

12 Interaction of Surface Water and Ground Water in the Dutch Flats Area, Western Nebraska, 1995-99 


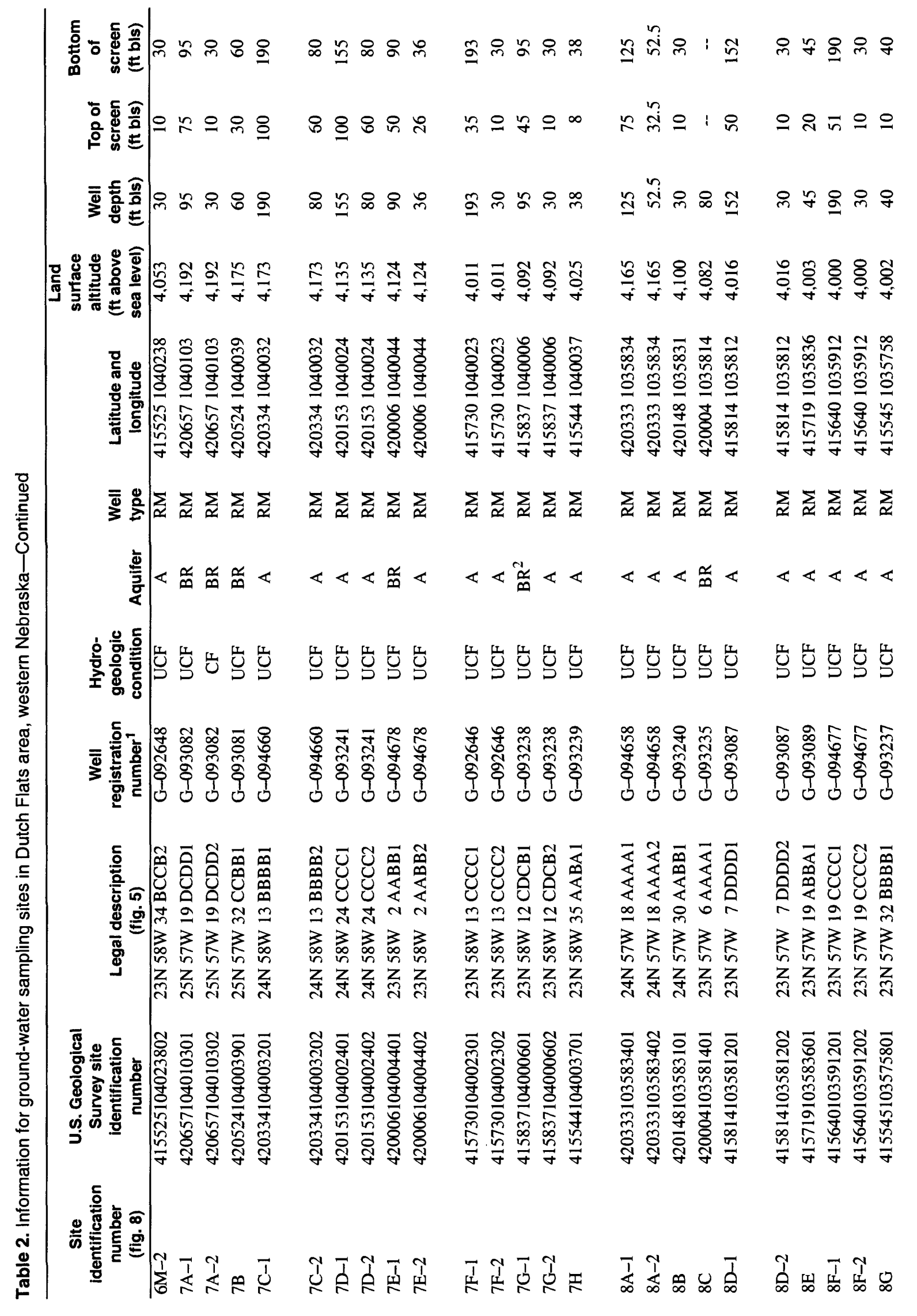




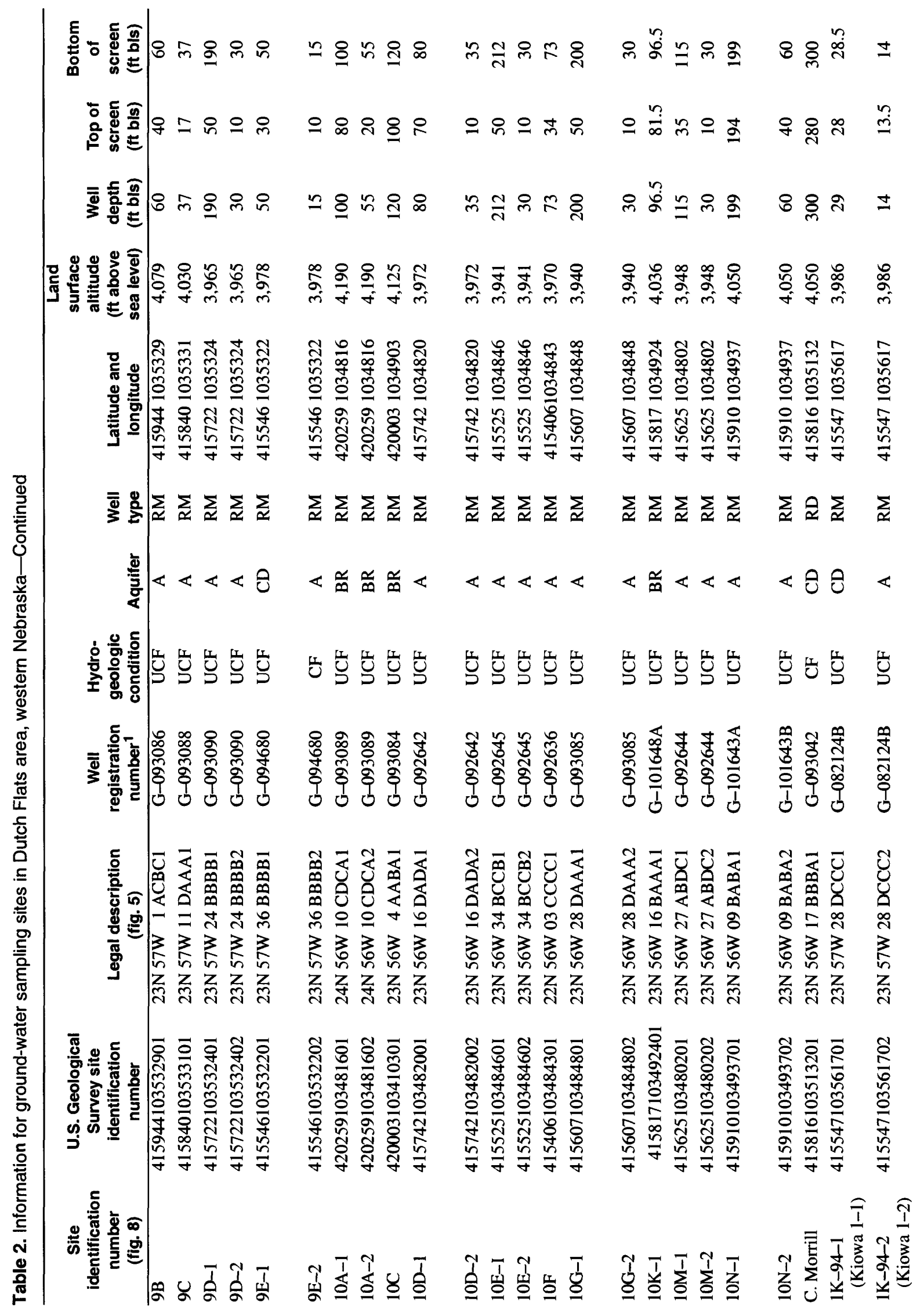




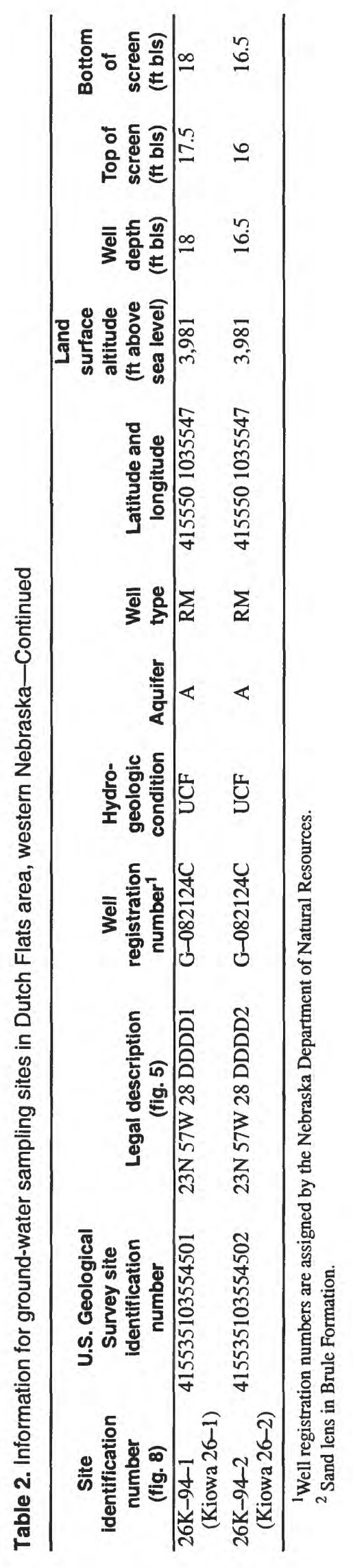

Methods 15 
Well number

24N 57W 15 CBBD1

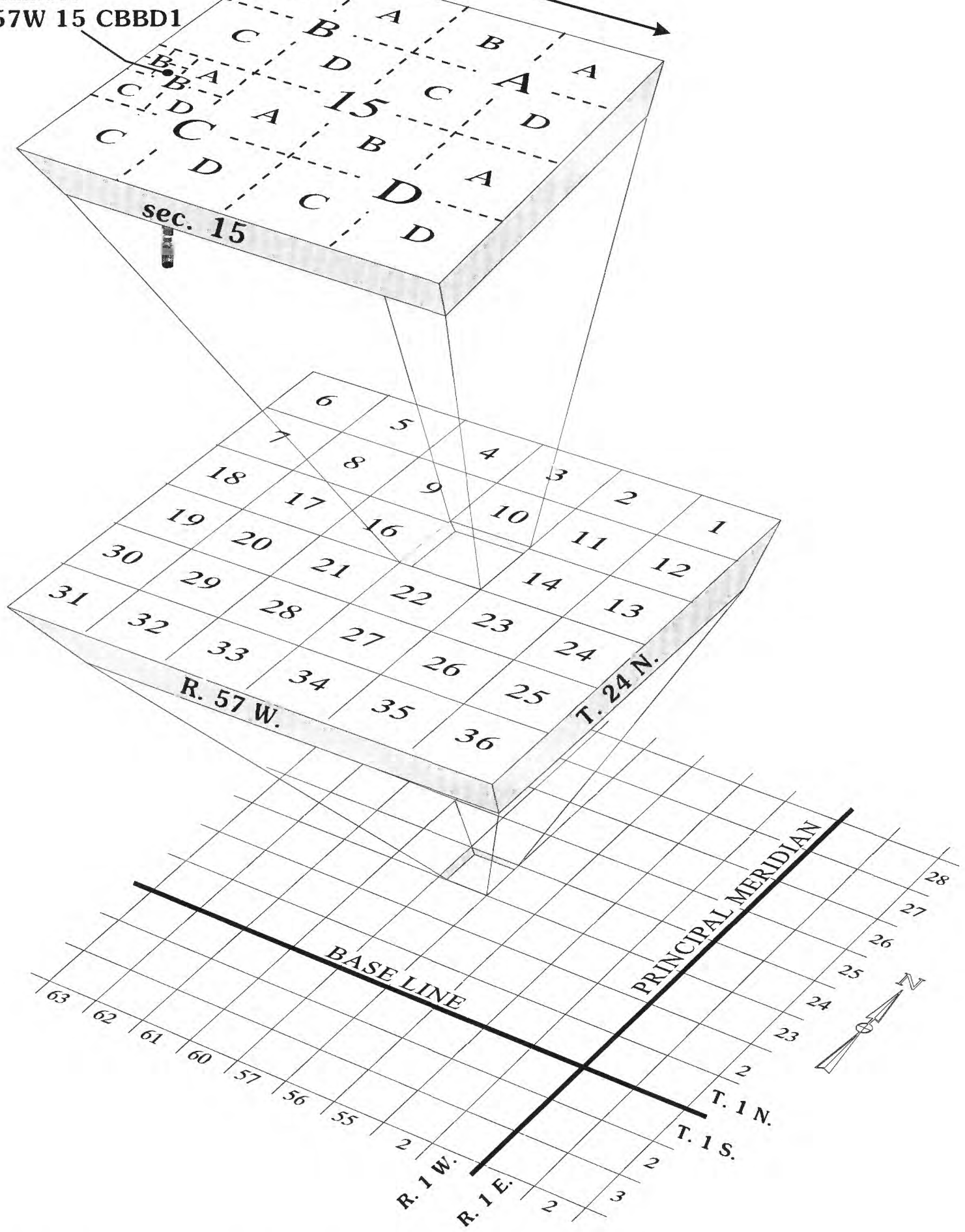

Figure 5. Legal-description numbering system. 
The sampling schemes were created on the basis of location and depth of wells constructed, the timing of water present in the canals, and perceived gaps in previously collected information. The spatial and temporal distributions of the samples collected mainly focused on obtaining data perceived to help define surface-water/ground-water interaction and other data of interest to the North Platte NRD and the State of Nebraska. The samples were analyzed for a subset of constituents thought to be useful indicators of surfacewater/ground-water interaction in the study area, including, but not limited to, specific conductance, sodium, calcium and magnesium (hardness), sulfate, nitrate, uranium, and radon. These elements, ions, or isotopes also have the potential to affect the suitability of water supplies in the study area.

The sampling schemes and analytes were modified each year as to frequency and timing of collection, especially near the Interstate Canal and North Platte River. The sampling schemes were followed unless weather conditions prohibited sample collection or unless sites were not accessed because of recent pesticide applications on nearby fields, causing a potential health hazard.

\section{Surface-Water Samples}

One hundred and thirty samples were collected from 11 surface-water sites from 1996 through 1999 (fig. 1). The most frequent sampling occurred on the North Platte River at Morrill (site SW9, 37 samples). In 1998 and 1999, sampling of the surface-water bodies contributing water to the North Platte River in the study area, except the wetlands, was conducted to help evaluate the sources of uranium in surface water (Verstraeten and others, 2000).

Surface-water samples were collected using equalwidth increment (EWI) sampling procedures or centroid-of-flow (COF) sampling procedures as described by Wells and others (1990). At the wetlands site near Morrill (site SW11), only a dip sample was collected. COF samples were collected from both canal sites (SW1 and SW3). Water in these canals is considered well mixed with minimal inflow from other surfacewater bodies (Steele and Cannia, 1997). EWI sampling was used at the remainder of the sites where streamflow was not considered well mixed. All waterquality samples were collected by wading the stream or suspending the sampler by hand from a bridge.

\section{Ground-Water Samples}

About 1,960 ground-water samples were collected from 152 ground-water sites from 1996 through 1999 (fig. 8 in section on "Hydrogeology"). The number of samples collected at a ground-water site varied from 1 sample at site $2 \mathrm{~T}$, constructed in 1999, to 36 samples at site 1C-3, constructed in 1994. Samples were collected from the nested-well sites described previously using a stainless-steel submersible pump. Specific conductance, $\mathrm{pH}$, water temperature, and dissolved oxygen were measured onsite at 5-minute intervals using a flow-through chamber. Samples were collected after these readings stabilized within preset limits or after at least three well volumes of water had been pumped out of the well.

\section{Laboratory Procedures}

Water samples generally were analyzed at the USGS National Water-Quality Laboratory in Denver, Colorado, following standard procedures (Verstraeten and others, in press). Water samples to be analyzed for uranium were sent to the USGS Uranium Research Laboratory in Reston, Virginia. Samples to be analyzed for dissolved gases were sent to the USGS Chlorofluorocarbon Research Laboratory in Reston, Virginia. Quality-assurance and quality-control procedures and data validation are summarized in Verstraeten and others (in press).

\section{Creation of Water-Table and Saturated- Thickness Maps}

The water-table and saturated-thickness maps in this report were created using historical data and data collected during this study. Water-table data from monitoring and irrigation wells were referenced to a common vertical datum (sea level). The data estimated from 1:24,000-scale topographic maps were contoured using an existing water-table map of the area as a reference (Babcock and Visher, 1951).

A map of the configuration of bedrock surface was created to generate the saturated-thickness map. The map showing the configuration of the bedrock surface in the study area was compiled using depth-to-bedrock data obtained during the installation of the monitoring wells and well-registration information for irrigation wells. The altitude of the bedrock surface was subtracted from the altitude of the water table to create the 
saturated-thickness map. Where little or no data were available, both the altitude of the water table and the saturated thickness were inferred.

\section{SURFACE WATER AND HYDROGEOLOGY}

This section describes in detail the surface water and hydrogeologic characteristics of the study area. The surface water and hydrogeologic characteristics affect the water movement through the study area.

\section{Surface Water}

The predominant surface-water systems in the study area are the North Platte River and the Interstate and Tri-State Canals (fig. 1). The North Platte River enters Nebraska at the Wyoming-Nebraska State line near Henry, Nebraska, and continues on a southeasterly path to its confluence with the South Platte River near the city of North Platte (fig. 1). The general gradient of the North Platte River through its reach in Nebraska is $0.0014 \mathrm{ft} / \mathrm{mi}$ (Goodwin and Diffendal, 1987).

Discharge in the North Platte River system (figs. 6 and 7) has been affected by human activities since the late 19th century (Kircher and Karlinger, 1983). These activities include transmountain diversions of the headwaters of the North Platte River, dams such as Seminoe, Pathfinder, Alcova, Glendo, and Guernsey in Wyoming and Kingsley Dam (forming Lake McConaughy) in Nebraska, and canals such as the Interstate and Tri-State Canals. Other human activities affecting river flow include diversions to satisfy surface-water irrigation rights, ground-water pumpage near surfacewater bodies to meet demands of increasing population, and irrigated agriculture, which require water for growing crops in the river valley. Humans also have affected flow in the North Platte River by reshaping or channelizing. All of these human activities generally result in flattening of daily flow-duration curves (fig. 7) or shifting in the levels of low or high flows in the North Platte River (Kircher and Karlinger, 1983).

The North Platte River is the source water for the Interstate and Tri-State Canals. Flow for the Interstate Canal is diverted from the North Platte River at the Whalen diversion dam near Fort Laramie, Wyoming (fig. 1). The course of the Interstate Canal runs parallel to the North Platte River for about $50 \mathrm{mi}$ where it intersects the Nebraska-Wyoming border, about $10 \mathrm{mi}$ north of the active river channel. The Interstate Canal follows a more irregular course along the contours of the land for an additional $29 \mathrm{mi}$ to the eastern edge of the study area. The mean daily flow of the Interstate Canal typically ranges from about 1,000 to $1,200 \mathrm{ft}^{3} / \mathrm{s}$ but depends on flows in the North Platte River (Dennis Strauch, Pathfinder Irrigation District, oral commun., 1999). It also is affected by precipitation and runoff. The Interstate Canal typically carries water for irrigation of hay and filling downstream lakes in April and May, and for irrigation of cropland from June through September. Timing of flows through the canal varies from year to year depending on climatic conditions.

The Tri-State Canal receives its water from a diversion dam on the North Platte River 1 mi east of the Wyoming-Nebraska State line. Mean daily flow in the Tri-State Canal typically ranges from 900 to $1,000 \mathrm{ft}^{3} / \mathrm{s}$ (Kevin Adams, Farmers Irrigation District, oral commun., 1999). The Tri-State Canal also receives water from diversion dams on four tributaries of the North Platte River. From May 1 to September 30, 1998, the Tri-State Canal received diverted water from Sheep Creek [about $67\left(\mathrm{ft}^{3} / \mathrm{s}\right) / \mathrm{d}$ ], Acres Draw [about $11\left(\mathrm{ft}^{3} / \mathrm{s}\right) / \mathrm{d}$ ], Dry Spottedtail Creek [about $12\left(\mathrm{ft}^{3} / \mathrm{s}\right) / \mathrm{d}$ ], and Spottedtail Creek [about $11\left(\mathrm{ft}^{3} / \mathrm{s}\right) / \mathrm{d}$ ] (Nebraska Department of Water Resources, 1998). Timing of flow into the Tri-State Canal is similar to that of the Interstate Canal, with the exception that there are no upstream impoundments for storage served by this system.

Tributaries of the North Platte River, which are much smaller in terms of discharge than the Interstate or Tri-State Canals, drain much of the study area north of the North Platte River. The largest tributary north of the river, Sheep Creek (fig. 1), is perennial only in the downstream reaches. In the upstream reaches, Sheep Creek typically flows only when ground water in the area is recharged with seepage from the Interstate Canal. Seepage from this canal causes ground-water levels to rise, resulting in discharge of ground water to the upstream reaches of Sheep Creek. Other tributaries of the North Platte River that lie north of the river are Dry Sheep Creek, which is perennial, and Spottedtail and Dry Spottedtail Creeks (fig. 1), which are seasonal. South of the North Platte River, Horse Creek is the predominant natural perennial surface-water feature (fig. 1). From 1995 through 1998, flows of the North Platte River varied from less than 200 to more than $5,000 \mathrm{ft}^{3} / \mathrm{s}$; flows of Sheep Creek varied from less 


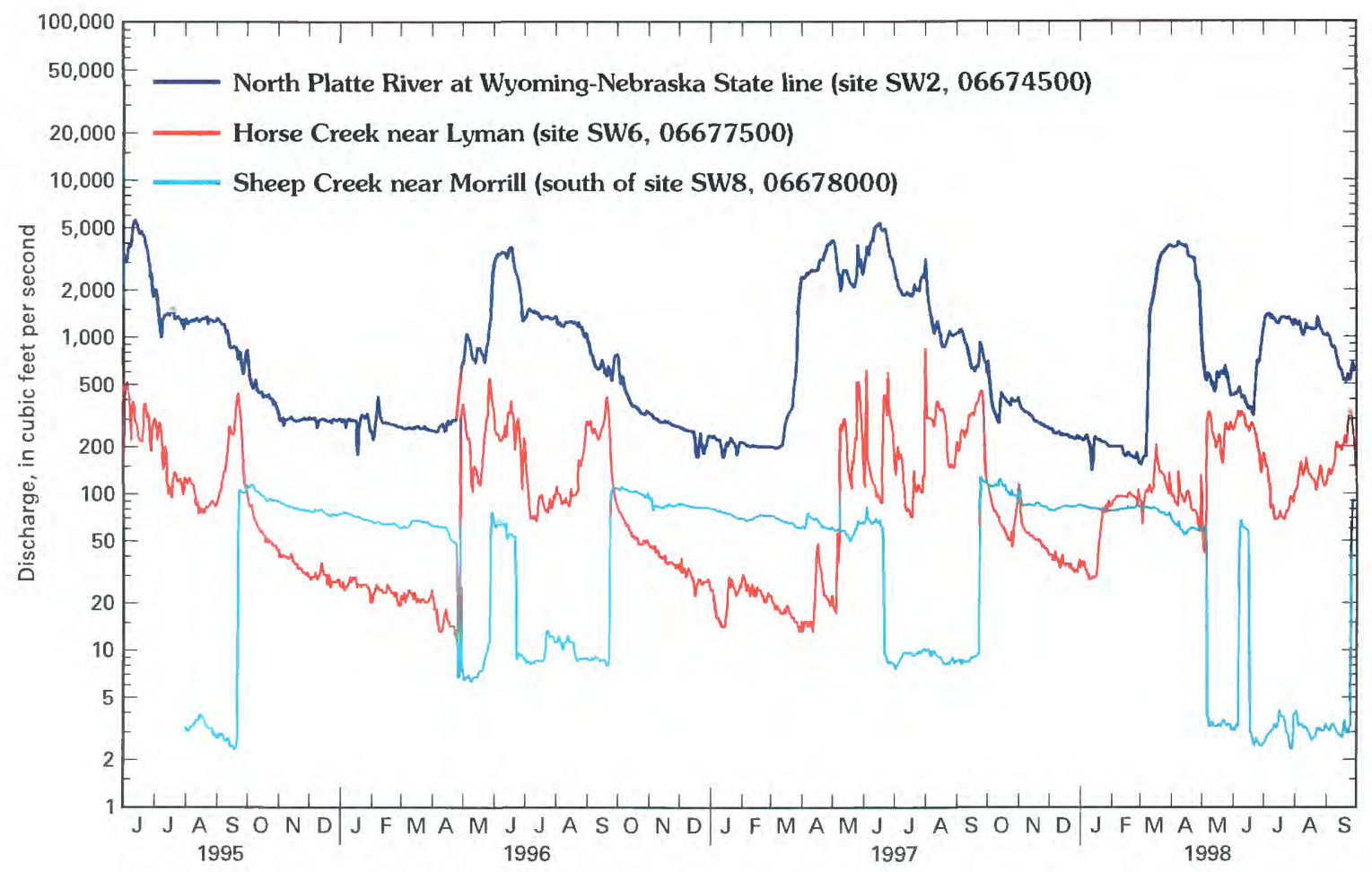

Figure 6. Discharge of North Platte River at Wyoming-Nebraska State line (site SW2, 06674500), Horse Creek near Lyman (site SW6, 06677500), and Sheep Creek near Morrill (06678000), Nebraska, 1995 through 1998. Locations of surface-water sampling sites are shown in figure 1.

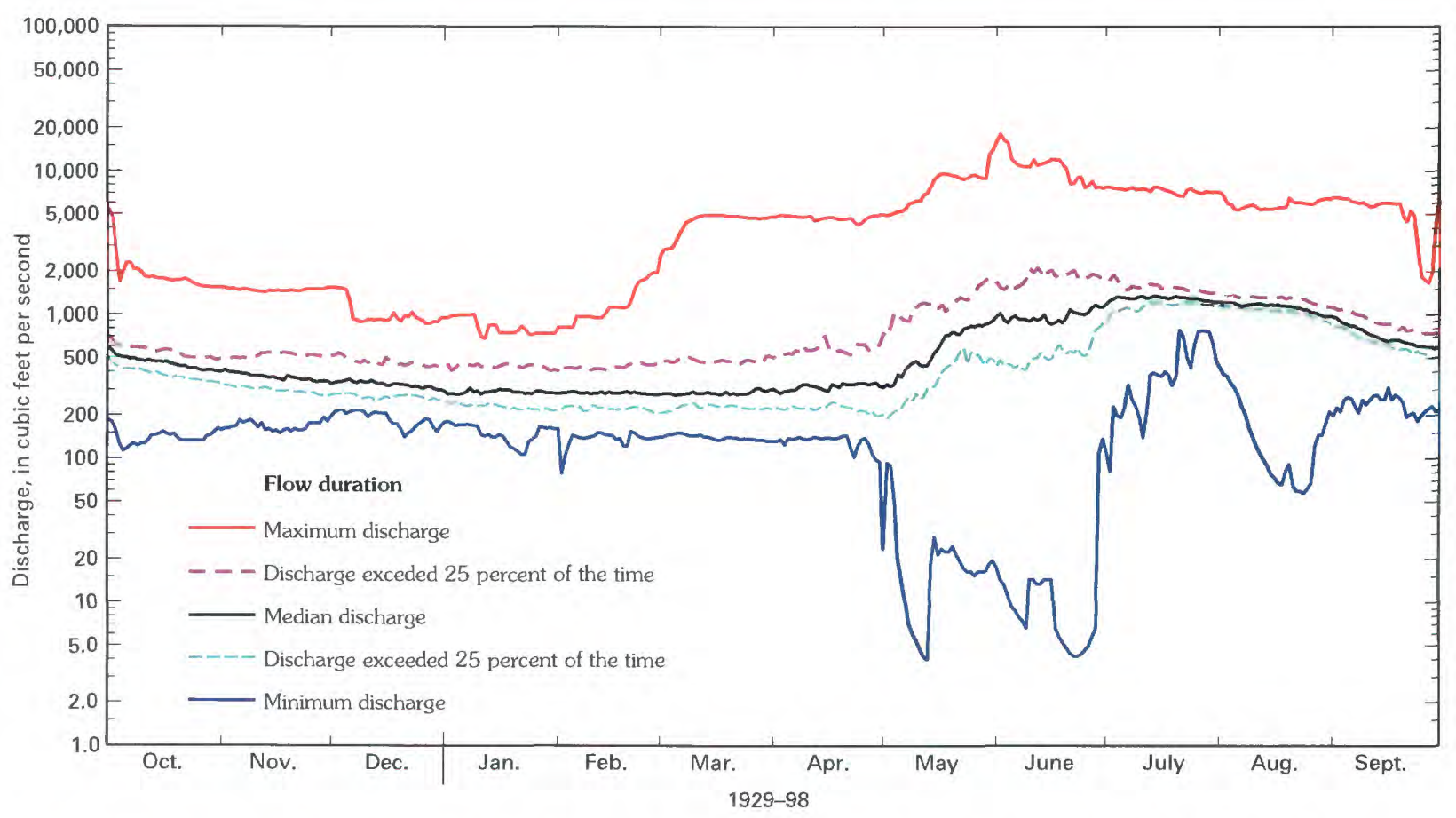

Figure 7. Daily flow duration of North Platte River at Wyoming-Nebraska State line (site SW2, fig. 1), 1929 through 1998. 
than 5 to more than $100 \mathrm{ft}^{3} / \mathrm{s}$; and flows of Horse Creek varied from less than 20 to as much as $700 \mathrm{ft}^{3} / \mathrm{s}$ (fig. 6). Generally, flows at the natural surface-water sites increased near the beginning of May and began to decline sometime in August (fig. 6). However, as shown in figure 6, Sheep Creek departs from the normal tendency. This departure is caused by the diversion of surface water from Sheep Creek to the TriState Canal upstream from sampling site 06678000 (fig. 1). Otherwise, the tendency for streamflow to increase in May and decline in August likely would be the same during the irrigation season.

\section{Hydrogeology}

Aquifers in the study area include the alluvial aquifer and the Brule, Chadron, and Lance bedrock aquifers. Previous investigations describe the geology and occurrence of ground water in the study area (Darton, 1903a, b; Wenzel and others, 1946; Babcock and Visher, 1951; Smith and Souders, 1975; Souders, 1986; Verstraeten and others, 1995). A summary of the principal hydrogeologic units in the study area is given in table 3. A map showing the surficial geology of the Dutch Flats area and the traces of generalized hydrogeologic sections is presented in figure 8. Generalized hydrogeologic sections are presented in figure 9.

This report uses USGS nomenclature to describe most bedrock units. However, the terms "Lance" and "Fox Hills aquifers" are used by the University of Nebraska-Lincoln Conservation and Survey Division. The USGS currently has not identified the presence of the Lance and Fox Hills Formations in Nebraska. However, they are thought to exist in extreme western Nebraska (Condra and Reed, 1959).

\section{Alluvial Aquifer}

The alluvial aquifer in the study area is unconfined (table 3), and for the purposes of this report, has been divided into a northern and southern aquifer separated by a bedrock high. This bedrock high separates the ancestral North Platte River Valley north of the bedrock high (the upland) from the present North Platte River Valley (the bottomland). It is parallel to the North Platte River and generally just north of the Tri-State Canal, providing a distinguishable topographic relief of as much as $100 \mathrm{ft}$.

Depth to the water table typically is less than 5 to $80 \mathrm{ft}$ below the land surface in the northern alluvial aquifer and typically is less than $20 \mathrm{ft}$ below the land surface in the southern alluvial aquifer. The saturated thickness of the alluvial aquifer in the study area (fig. 10) varies from less than $5 \mathrm{ft}$ near the valley walls to more than $200 \mathrm{ft}$ near the present day North Platte River. Babcock and Visher (1951) report a hydraulic conductivity of $300 \mathrm{ft} / \mathrm{d}$ and a specific yield of about 0.32 from an aquifer test in the northern alluvial aquifer. Two unpublished aquifer tests conducted by the USGS and the North Platte NRD in the southern alluvial aquifer indicate hydraulic conductivities of 99 and $463 \mathrm{ft} / \mathrm{d}$ at Morrill (ground-water sampling site $1 \mathrm{H}$, fig. 8) and at Mitchell (site 10M, fig. 8), respectively. Values of specific yield at these two sites probably are representative of the southern alluvial aquifer, but actual values can vary locally at least 10 fold (data on file with U.S. Geological Survey, Lincoln, Nebraska).

Most ground-water movement in the Dutch Flats area is toward the North Platte River (fig. 11). In the northern alluvial aquifer, partial obstruction of ground-water movement by the bedrock high in the Brule Formation locally can cause ground water to deviate from the predominant north-south direction of flow. In the part of the southern alluvial aquifer north of the North Platte River, ground water moves predominantly from areas recharged by ground water from the northern alluvial aquifer toward the North Platte River. In the southern alluvial aquifer south of the North Platte River, ground water predominantly moves east-northeasterly and toward the North Platte River. As ground water approaches the North Platte River, ground-water flow paths generally turn, and ground water moves east-southeast down the valley until discharging into the North Platte River when the stage of the river is lower than the ground-water level.

Previous studies have reported that the North Platte River and the alluvial aquifer are hydraulically connected and exchange water. Herrmann (1976) reported that the North Platte River Valley in Wyoming does not gain or lose substantial water to the alluvial aquifer. Lappala and others (1979) reported that downstream of the study area the Platte River and the underlying alluvial aquifer are hydraulically connected. The hydraulic connection allows the North Platte River to act as a control on the water levels in the ground-water system, and changes in ground-water levels are observed within minutes of a rise in river stage. When ground-water levels change, the levels will be maintained as long as the change in river stage exists. Thus, locally, a high river stage will result in 


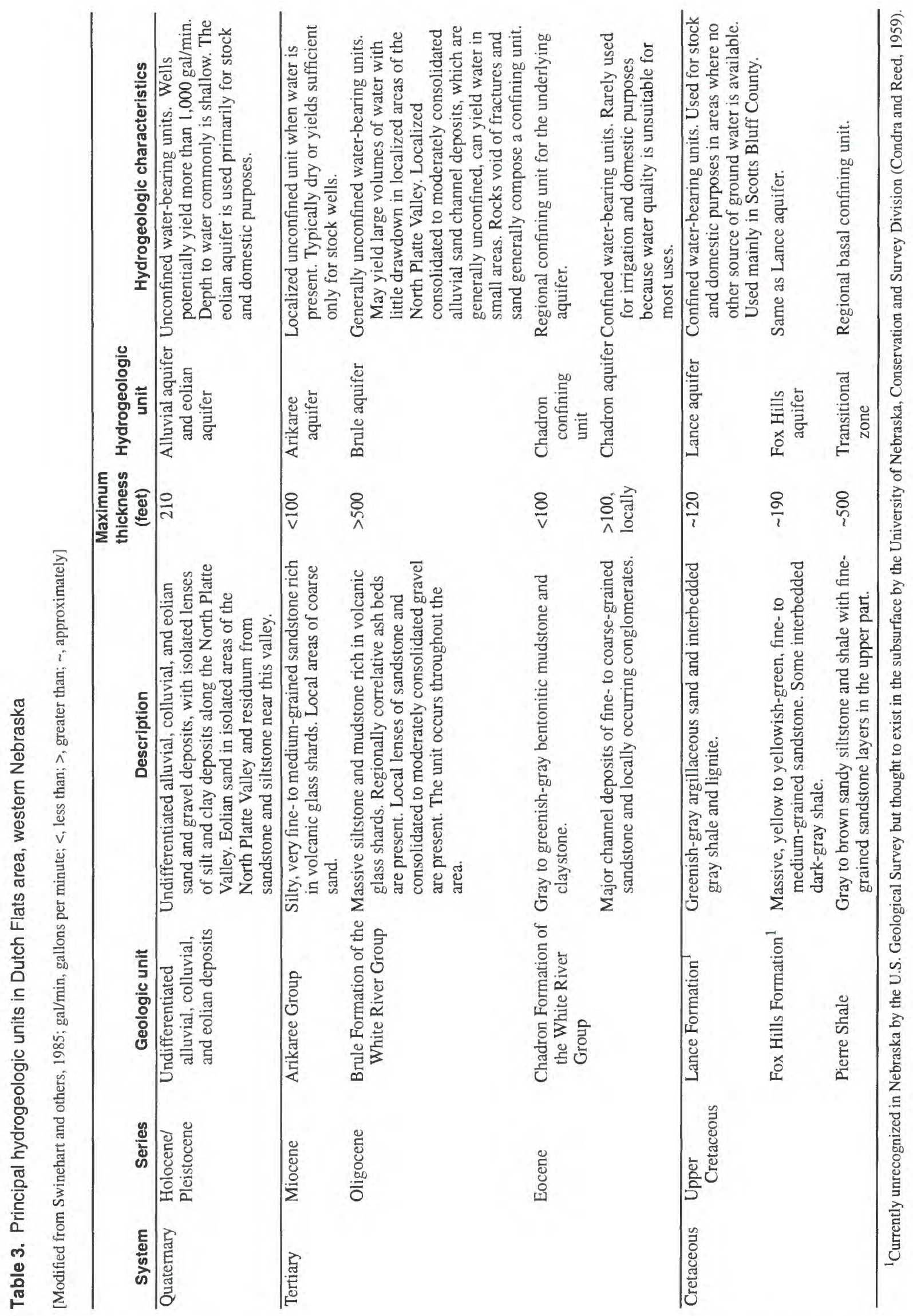




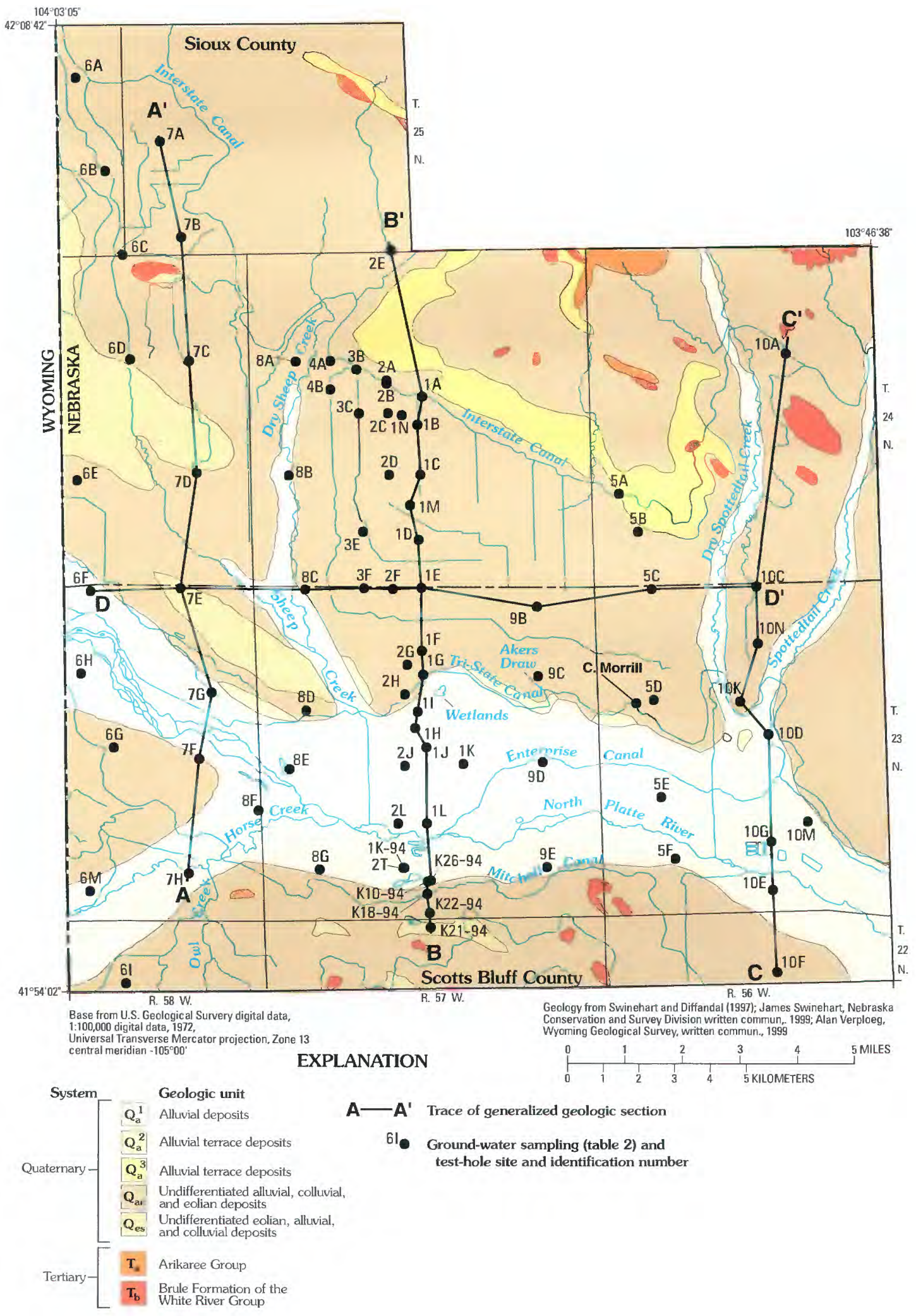

Figure 8. Surficial geology and traces of generalized geologic sections, ground-water sampling sites, and test holes, Dutch Flats area. 
higher ground-water levels, and a low river stage will result in lower ground-water levels. Consequently, if the river stage returns to its original stage, long-term residual effects on ground-water levels will not occur (Hurr, 1981). Hurr (1981) reported that withdrawals of ground water near the Platte River may affect groundwater levels in at least two ways - first, by initiating drawdowns of ground-water levels, and second, by causing river-stage decline, which may result in further declines in ground-water levels and surface-water streamflow farther downstream.

Stresses on the ground-water system from pumping or recharge are subject to magnitude and timing (Burns, 1983). The effects of these stresses (pumpage or recharge) largely are dependent upon the aquifer's hydraulic characteristics, such as transmissivity, specific yield (for water-table aquifers), the hydraulic connection between the stream and aquifer, and the distance from the point of stress to the stream. Sophocleous and others (1995) reported that quantifying the primary hydraulic characteristics of the aquifertransmissivity and storage coefficient-might not be as critical in surface-water/ground-water interactions because local streambed "clogging" plays an important part in the degree of interaction. The more fine materials in the streambed, the less interaction between the stream and aquifer. Streambed clogging also affects the magnitude of streamflow accretion or depletion caused by surface-water/groundwater interaction.

Recharge to the ground-water system in the Dutch Flats area by precipitation is much less than recharge to the ground-water system by infiltration of water seeping from irrigation canals and laterals and by infiltration of water applied for irrigation (Babcock and Visher, 1951). Consequently, any rises in groundwater levels caused by precipitation likely are obscured by the much greater rises in ground-water levels from infiltration of surface-water seeping from the canals and water applied to the fields for irrigation. In this study, direct recharge of the ground-water system caused by infiltration of water seeping from the canals and laterals was reflected in water-level rises in some monitoring wells, including wells $1 \mathrm{~A}-3$ and 2A-1 adjacent to the Interstate Canal (fig. 12). Waterlevel rises appeared shortly after surface water was diverted into the Interstate and Tri-State Canals. Within about 20 days of filling the canals, water levels rose as much as $4 \mathrm{ft}$ in monitoring well $1 \mathrm{~A}-3$ (fig. 12) adjacent to and downgradient from the Interstate
Canal. After the surface-water diversions stopped and the flow in the canals ceased, water levels began to decline in monitoring wells near the canals that showed responses to canal seepage.

Freeze (1969) reported that antecedent soil moisture is likely the most important characteristic that affects the amount of ground-water recharge. Therefore, it was presumed for the Dutch Flats study area that because the canals seep, the soil generally is totally saturated and allows for substantial recharge to the aquifer. Hence, recharge was estimated using the projected downward trend in water levels in the monitoring wells as described in Babcock and Visher (1951). The downward trends were projected from the decline during the previous winter to the time when water levels reached a seasonal high. The difference between the projected low and the seasonal high water levels multiplied by the specific yield was assumed to equal the gross recharge occurring at that monitoring well site. Using this method, estimation of recharge at monitoring well $1 \mathrm{~A}-3$ generally agreed with the estimate of Babcock and Visher (1951) of $3 \mathrm{ft}$ per summer (June, July, and August).

\section{Bedrock Aquifers}

Bedrock aquifers in the study area include the Brule, Chadron, and Lance aquifers. The bedrock aquifers typically are used when appreciable yields from the alluvial aquifer cannot be obtained.

\section{Brule Aquifer}

The Brule aquifer (table 3 ) generally is unconfined with sustainable yields only in areas that contain secondary porosity from fissures and cracks or, less commonly, fluvial sand units. Ground water in the localized fluvial sand units typically can be encountered at depth but generally is not considered areally extensive and largely is unmapped. In areas where the Brule aquifer is near the land surface, depths to water vary from less than $5 \mathrm{ft}$ near the perennial drainages to 25 to $40 \mathrm{ft}$ near the Tri-State Canal. In areas where the aquifer is not near the land surface, depth to water can be $130 \mathrm{ft}$. Porosity of two core samples of the Brule Formation collected in the study area was reported to be 52.5 percent (Wenzel and others, 1946). Permeability of the consolidated material is so low that water does not flow into a well developed in areas where fissures, cracks, or sand units are not present. Over time, 

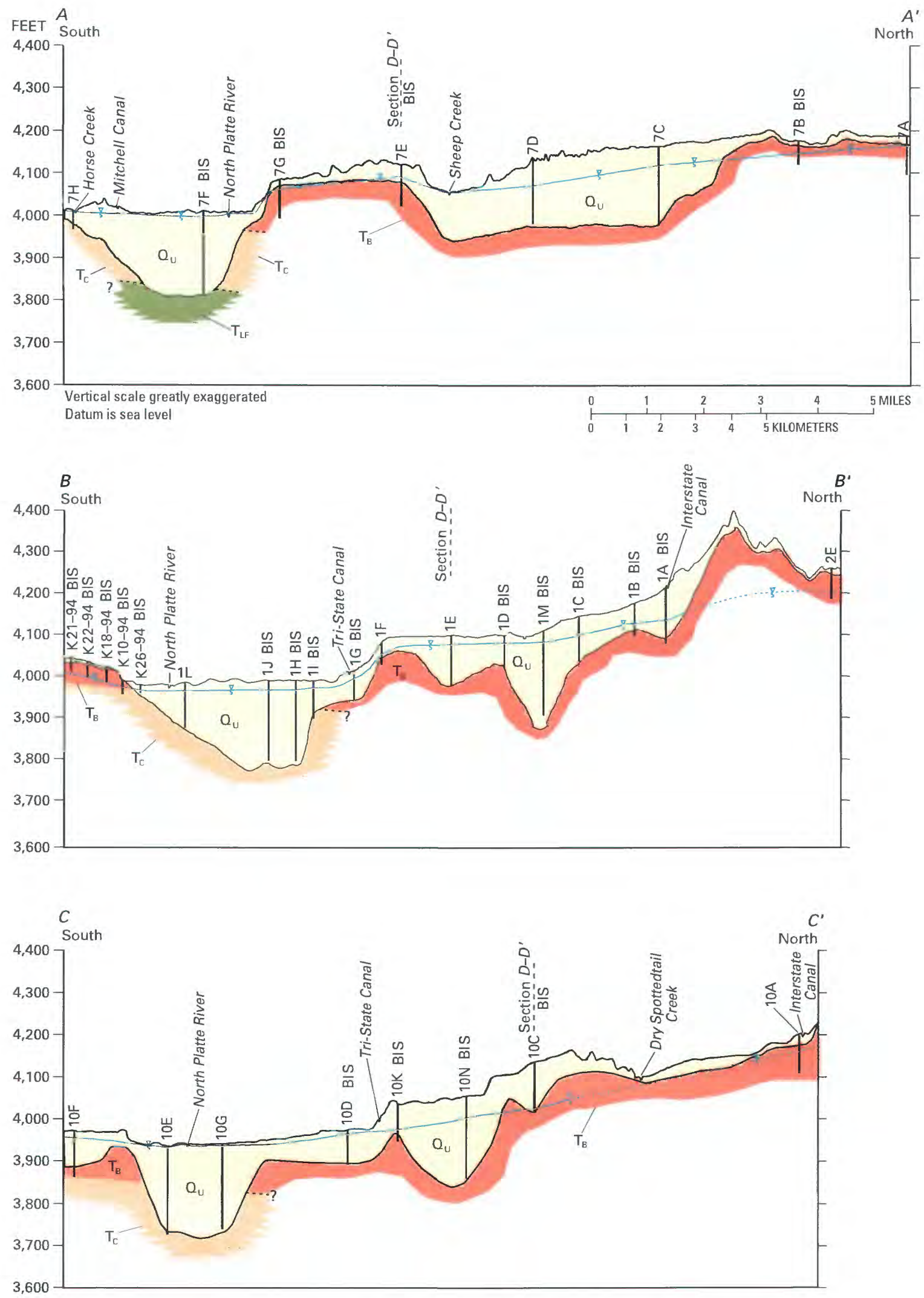

Figure 9. Generalized geologic sections $A-A^{\prime}$ through $D-D^{\prime}$ showing principal geologic units transected by ground-water sampling sites and test holes, Dutch Flats area. Traces of sections are shown in figure 8. 

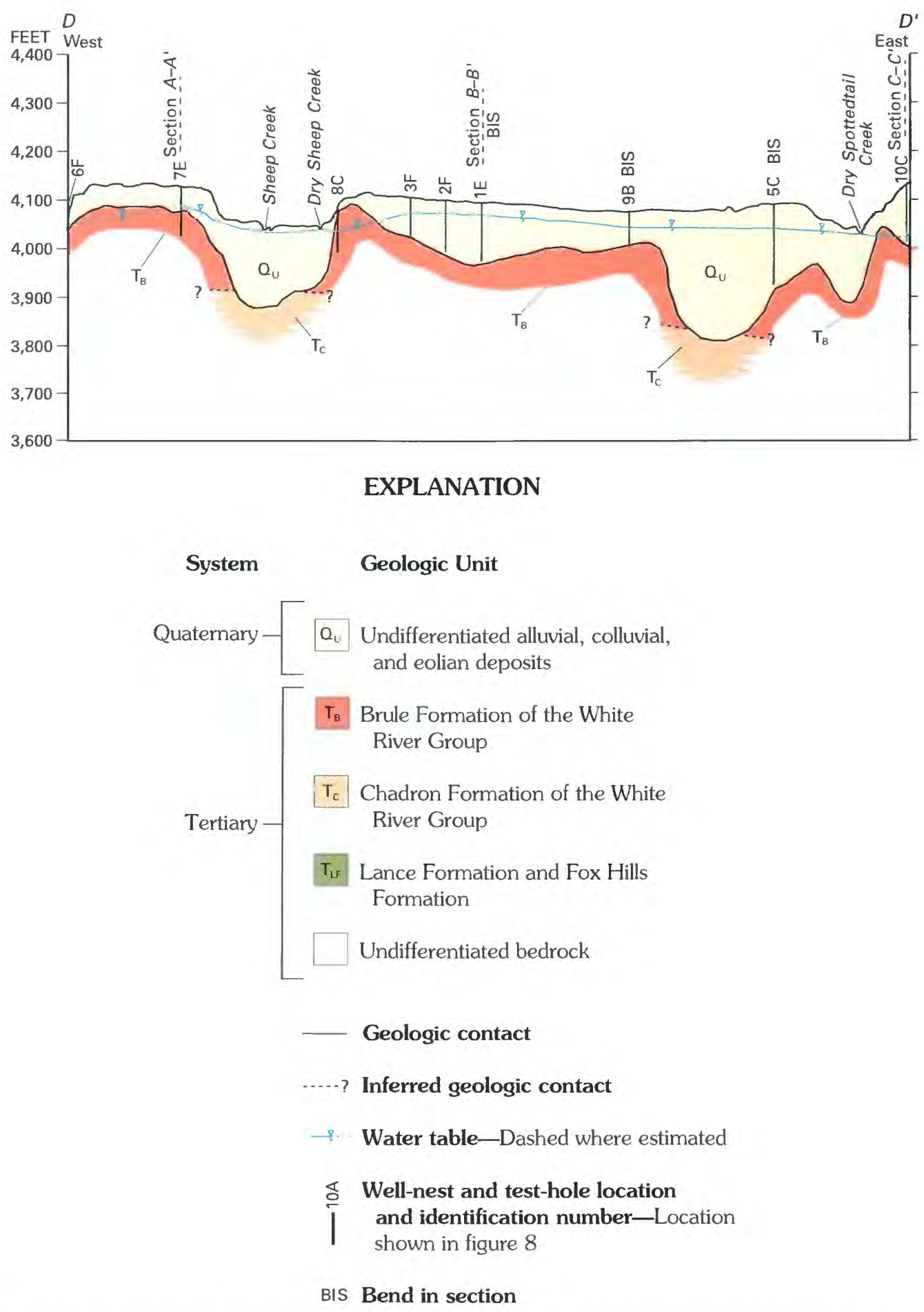

Figure 9. Generalized geologic sections $A-A^{\prime}$ through $D-D^{\prime}$ showing principal geologic units transected by ground-water sampling sites and test holes, Dutch Flats area-Continued. Traces of sections are shown in figure 8. 


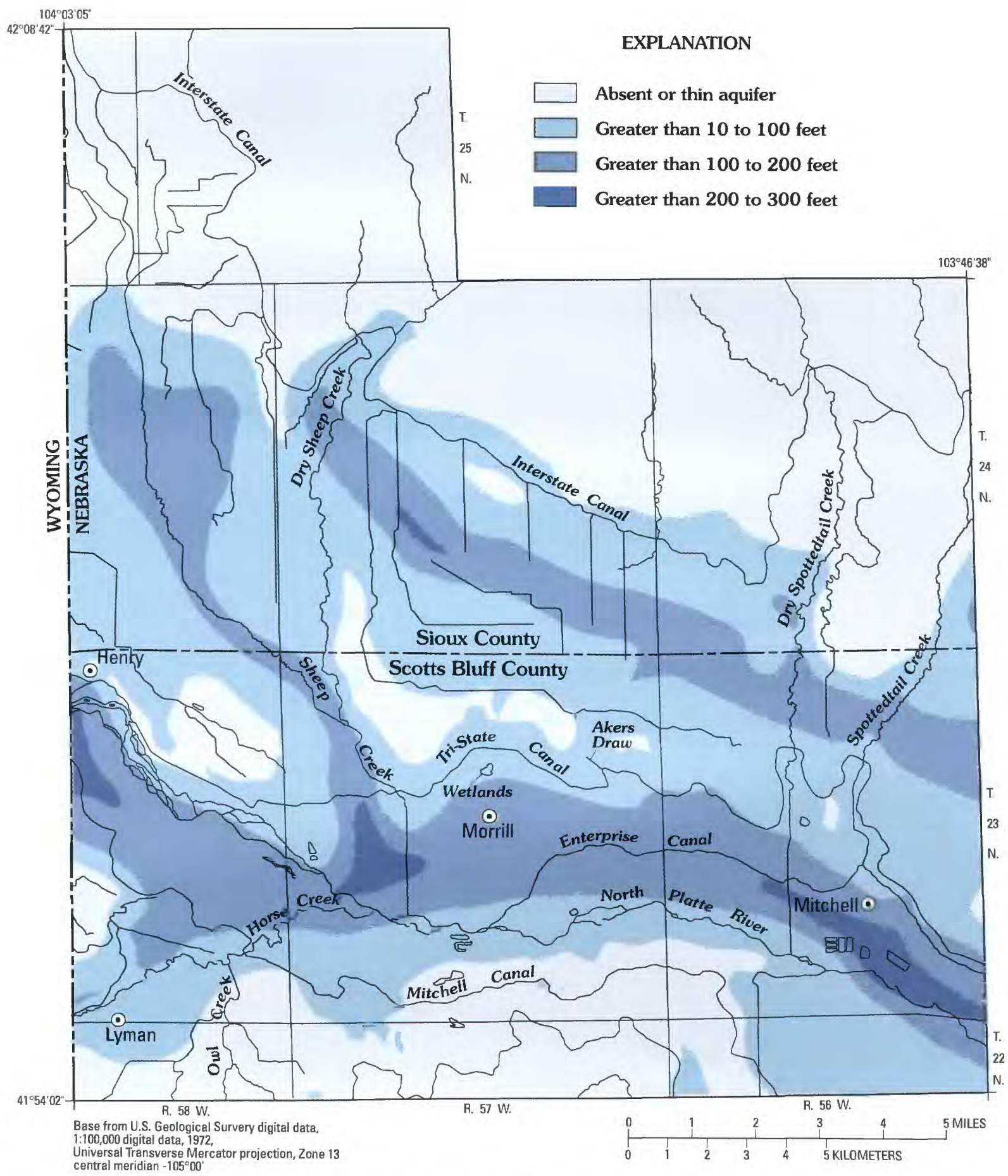

Figure 10. Saturated thickness of alluvial aquifer, Dutch Flats area, summer 1998. 


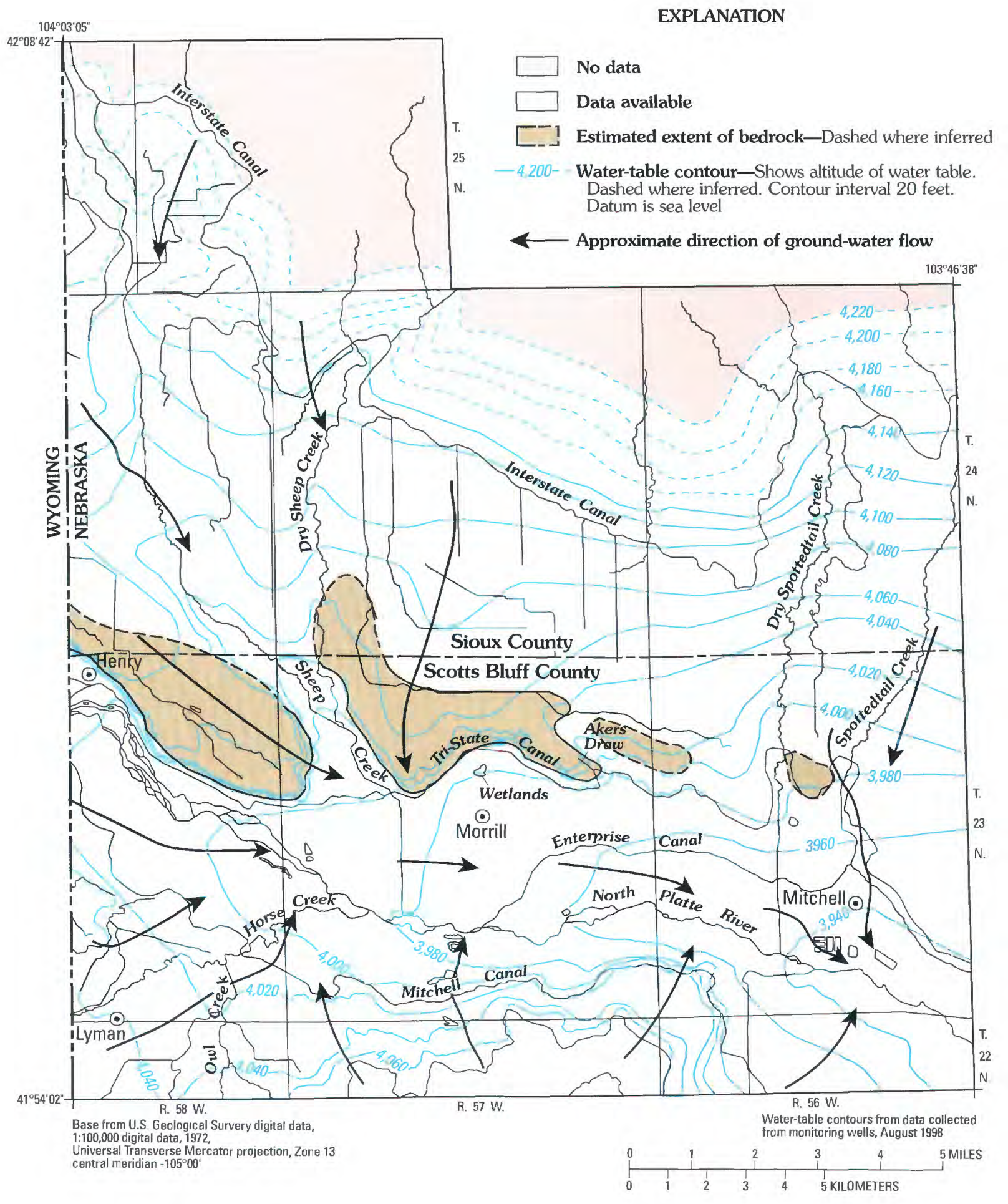

Figure 11. Configuration of water table in alluvial aquifer, Dutch Flats area, summer 1998. 


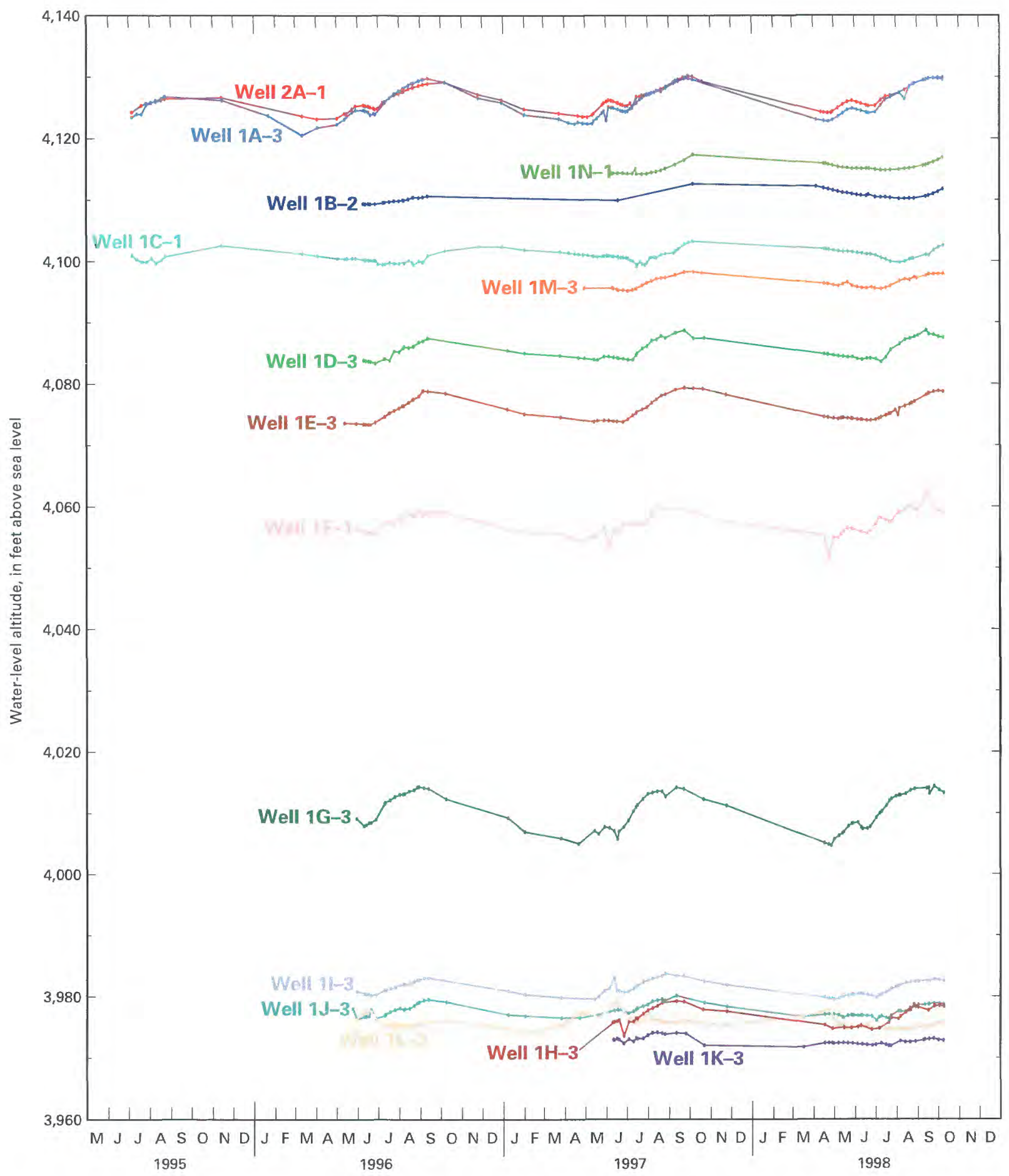

Figure 12. Water levels in selected monitoring wells along section B-B', Dutch Flats area, May 1995 through September 1998. Locations of wells are shown in figure 8. 
water will percolate slowly into a well, and the water level will rise to the level of the water table.

In the study area, yields to wells in the Brule aquifer typically are sufficient for domestic and stock use. Locally, however, yields to wells can differ considerably. Sustainable yields to wells are dependent upon the amount of recharge and the number, size, and continuity of the fractures. Water supplies from the Brule aquifer are greatest in areas nearest the irrigation canals (Wenzel and others, 1946). In these areas, seepage from the irrigation canals and the irrigated fields results in large volumes of recharge to the aquifer. This recharge is typically much larger than in areas where the only recharge to the aquifer is from precipitation.

\section{Chadron Aquifer}

The Chadron aquifer is confined by bentonitic mudstone and claystone of the Chadron confining unit (Verstraeten and others, 1995). The confining unit has not been mapped in detail but is thought to underlie most of the study area. The basal water-bearing unit of the Chadron aquifer consists of sandstone and conglomerate deposited in paleovalleys. Where present, the Chadron aquifer generally underlies the alluvial aquifer and the Brule aquifer. Because the Chadron aquifer is confined, depth to water in wells completed in the Chadron aquifer in the study area is typically 5 to $20 \mathrm{ft}$ below the land surface. This aquifer is rarely developed because of the great depth to the aquifer or unsuitable water quality (Verstraeten and others, 1995).

\section{Lance Aquifer}

In the study area, the Lance aquifer is confined and underlies the Chadron aquifer (table 3). Former river systems incised the overlying bedrock formations and exposed the Lance Formation at depth, such as in the southwestern part of the study area. Typical depth to water in wells completed in the Lance aquifer in the study area is about $15 \mathrm{ft}$ below land surface. Yields to wells developed in the Lance aquifer typically are small-as much as $1 \mathrm{gal} / \mathrm{min}$ (Wenzel and others, 1946). Wells in the Lance aquifer generally are used only for stock and domestic supplies and only when other sources of water are unavailable.

\section{SELECTED WATER-QUALITY CONSTITUENTS IN SURFACE AND GROUND WATER}

Water, especially ground water, acts as a geologic agent by its ability to interact with the environmert, the sediment or solid phase, and biota. Water chemistry generally is described by its ionic composition but, recently, also has been described and better understood through evaluation of dissolved gases and selected isotopes as tracers of water or contaminants. Isotopes are atoms of the same element that have different masses; they have the same number of protons and electrons but a different number of neutrons. Variations of isotope ratios generally are small and, therefore, are commonly expressed as the parts-per-thousand difference between the isotope ratio of a standard ( $\delta$ units).

Radionuclides are isotopes of elements that change, into other elements by radioactive decay. Uranium$238\left({ }^{238} \mathrm{U}\right)$ and uranium-234 $\left({ }^{234} \mathrm{U}\right)$ are long-lived radioactive nuclides that have been used to identif"' mixing of water masses and to investigate surfacewater/ground-water interaction. Radon- $222\left({ }^{222} \mathrm{Rn}\right)$ is a decay product of ${ }^{234} U$.

In this report, the discussion of the spatial distribution of the selected water-quality consituents generally is limited to the data collected during the summer of 1998 when almost all wells were sampled within a 2-week period. However, the discussion of the spatial distribution of uranium concentrations mainly focuses on data collected in the summers of 1998 and 199 .

Minimum, median, and maximum concentrations mentioned generally are for data collected from $15 ? 5$ through 1999, unless it is specified that they are 1 ? ?8 or 1999 data. Changes in chemistry with time, although occasionally mentioned in this section, generally are discussed in the section on surfacewater/ground-water interaction. All water-quality data referred to in this report are included in USGS reports (Boohar and Walczyk, 1997, 1998; Boohar, 2000; Verstraeten and others, in press) and can be retrieved from the USGS National Water Information System database.

\section{Physical Properties}

Onsite measurements of specific-conductance values and dissolved oxygen varied widely between surface-water and ground-water sampling sites. The $\mathrm{pH}$, which tended to be more than 7.7 in surface water, 
ranged from 7.1 to 7.8 in the alluvial aquifer and was as much as 8.5 in the bedrock aquifers.

\section{Specific Conductance}

Specific-conductance values in water from the North Platte River (sites SW2 and SW9) or in water from the canals (sites SW1 and SW3) diverted from the river ranged from 400 to $1,050 \mu \mathrm{S} / \mathrm{cm}$ at $25^{\circ} \mathrm{C}$ from 1995 through 1999. Larger values were recorded during the winter, and smaller values were recorded during the spring and early summer. Specificconductance values in water from the Interstate Canal (site SW1) varied from 427 to $733 \mu \mathrm{S} / \mathrm{cm}$. Specificconductance values in water from the wetlands site (SW11) were relatively large, generally greater than $1,000 \mu \mathrm{S} / \mathrm{cm}$, especially during dry periods. They ranged from 832 to $2,930 \mu \mathrm{S} / \mathrm{cm}$. Specificconductance values in water from Sheep (site SW8) and Dry Sheep (site SW7) Creeks, which receive their water during base flow from the alluvial aquifer, varied from 774 to $896 \mu \mathrm{S} / \mathrm{cm}$; these values are typical for shallow ground water in this area. Specificconductance values in water from Horse Creek (sites SW4 and SW6) were larger than those in water from Dry Sheep (site SW7) and Sheep (site SW8) Creeks and ranged from 838 to $1,080 \mu \mathrm{S} / \mathrm{cm}$.

In ground water, the largest specific-conductance value was measured in water from well 6 I completed in the Lance aquifer $(1,770 \mu \mathrm{S} / \mathrm{cm}$ in August 1998).

Water from the alluvial, Chadron, and Lance aquifers had larger specific-conductance values than water from the Brule aquifer and the surface-water sampling sites. Water from wells completed in bedrock tends to have large amounts of dissolved solids, which result in large specific-conductance values, and water from wells completed in the alluvial aquifer tends to have small specific-conductance values. Specificconductance values in water from the northern alluvial aquifer in the study area were smaller than in water from the southern alluvial aquifer. The largest specific-conductance values generally collected during the summer of 1998 were measured in shallow ground water near the North Platte River (well 1L-3 with $1,380 \mu \mathrm{S} / \mathrm{cm}$; well $7 \mathrm{H}$ with $1,570 \mu \mathrm{S} / \mathrm{cm})$ and near and in water from the bedrock aquifers (well 26K-94 with $1,510 \mu \mathrm{S} / \mathrm{cm}$; well $8 \mathrm{~F}-1$ with $1,690 \mu \mathrm{S} / \mathrm{cm}$; and well $6 \mathrm{I}$ with $1,770 \mu \mathrm{S} / \mathrm{cm}$ ) (fig. 13). In water from the northern alluvial aquifer, specific-conductance values generally were less than $1,000 \mu \mathrm{S} / \mathrm{cm}$.
Specific-conductance values in water from the Interstate Canal and in ground water immediately upgradient from the canal were different. However, differences in specific-conductance values between surface and ground water were not as obvious near the Tri-State Canal and were variable near the North Platte River. Large specific-conductance values in ground water near the bedrock south of the North Platte River may indicate ground-water flow from the bedrock aquifers into the alluvial aquifer from the south to the northeast (fig. 13).

\section{Dissolved Oxygen}

Dissolved-oxygen concentrations in the surface water generally were larger than $7.0 \mathrm{mg} / \mathrm{L}$. Dissolvedoxygen concentrations in shallow ground water were highly variable, ranging from near zero naar bedrock, near the North Platte River, or near wetland areas, to about $13 \mathrm{mg} / \mathrm{L}$ in other areas. Along and south of the North Platte River, where the bottomland sediment is fine and tends to contain abundant organic matter, or in the Chadron aquifer, the ground water wes totally depleted of dissolved oxygen in places. At depth, especially in the southern alluvial aquifer, the dissolved-oxygen concentrations in water samples were less than $2.0 \mathrm{mg} / \mathrm{L}$, and in some places ware zero (water from wells $1 \mathrm{~J}-1,1 \mathrm{~L}-1,1 \mathrm{~K}-94-1$, and 26K-94-1).

Dissolved-oxygen concentrations near zero suggest that near-reducing to reducing conditions may exist or that these water samples were collected at a redoxcline-a region where an oxidizing environment gradually changes with depth into a reduring environment with small amounts of dissolved ox:'gen or no dissolved oxygen (anoxic) present. Ground water in the alluvial and Brule aquifers tends to be the most oxic on the basis of data collected during the summers of 1998 and 1999. Water from the alluvial aquifer had a median dissolved-oxygen concentration of $5.4 \mathrm{mg} / \mathrm{L}$ (117 samples); water from the Brule aquifer had a median dissolved-oxygen concentration of $7.4 \mathrm{mg} / \mathrm{L}$ (18 samples); and water from the Chadron aquifer tended to be anoxic (median dissolved-ox ygen concentration of $0.2 \mathrm{mg} / \mathrm{L}$ for four samples). Water collected from well 6I, completed in the Lance aquifer, had a dissolved-oxygen concentration of $1.4 \mathrm{mg} / \mathrm{L}$. 


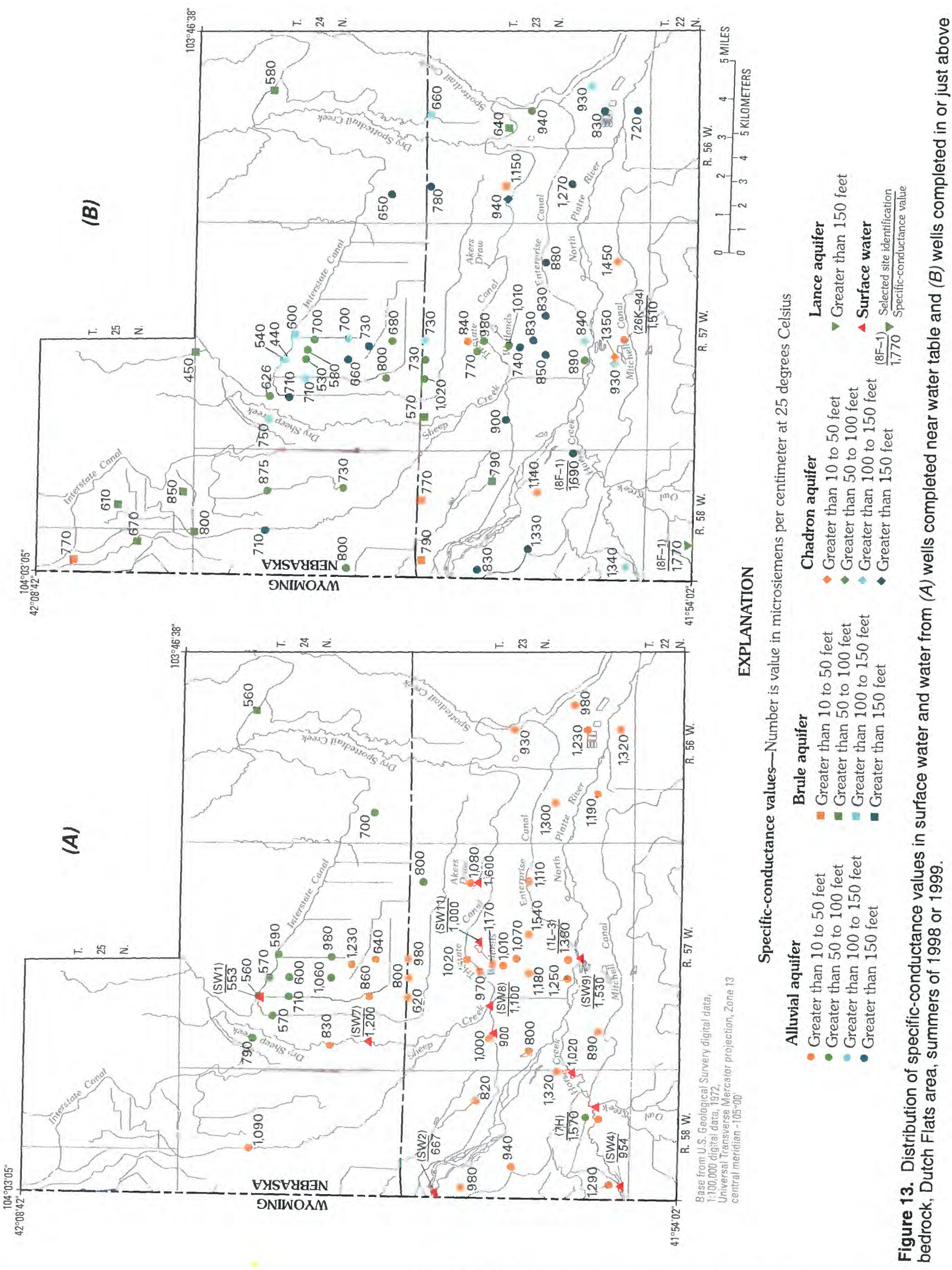




\section{Selected Major lons}

Major ions also varied between surface-water and ground-water sampling sites and along flow paths. In the study area, the aquifer lithology is the predominant factor affecting the ground-water chemistry as dilute water from precipitation and surface water interact with aquifer materials.

Large concentrations of sodium and sulfate in the water from the southern alluvial aquifer near the North Platte River suggest mixing of water in the alluvial aquifer with water from the underlying shale or dissolution of salt, gypsum minerals, or sulfides such as pyrite in the sediment. These large sulfate concentrations occurred in water near a redoxcline or near the Chadron and Lance Formations, indicating that oxidation of pyrite could be taking place.

The ionic composition of water from the alluvial aquifer generally showed a calcium sulfate signature, and the ionic composition of water from the Brule, Chadron, and Lance aquifers generally showed a sodium bicarbonate signature (fig. 14). Water from the North Platte River was intermediate between the ionic compositions of the calcium and sodium bicarbonate types. Mixing of water from the Chadron and Lance aquifers with water from the alluvial aquifer was evident (fig. 14) (water from wells $1 \mathrm{H}-1$ and 26K-94-1).

Water from the Lance aquifer (well 6I) had large sodium, chloride, sulfate, silica, and bicarbonate concentrations. Larger concentrations of sodium, chloride, and bicarbonate were present in samples collected from the Chadron aquifer (well 1K-94-1) than in samples collected from the alluvial and Brule aquifers. Water from the Brule, Chadron, and Lance aquifers had smaller concentrations of calcium and magnesium than water from the alluvial aquifer. Finally, water from the alluvial aquifer near the North Platte River (well 1J-1) had smaller concentrations of silica and larger concentrations of sulfate (200 mg/L), sodium (64 mg/L), and fluoride $(0.43 \mathrm{mg} / \mathrm{L})$ than water from the rest of the alluvial aquifer.

Bicarbonate, alkalinity, and sulfate concentrations indicate that ground water from the north-central part of the study area (well 2E-1) evolved towards water with larger concentrations of bicarbonate as it moved from the north to the south from the Brule aquifer, through the northern alluvial aquifer, and into the southern alluvial aquifer where it mixed in part with water from the Chadron and Lance aquifers. In the southern alluvial aquifer, ground water also was affected by the chemistry of the Chadron and Lance aquifers at depth in water from wells completed near the contact with bedrock [water from wells $6 \mathrm{G}-1$ (320 mg/L sulfate and $123 \mathrm{mg} / \mathrm{L}$ sodium), $7 \mathrm{H}$ (340 $\mathrm{mg} / \mathrm{L}$ sulfate and $191 \mathrm{mg} / \mathrm{L}$ sodium), and $8 \mathrm{~F}-1$ (400 mg/L sulfate and $191 \mathrm{mg} / \mathrm{L}$ sodium)] and in shallow water [water from wells $1 \mathrm{I}-3(300 \mathrm{mg} / \mathrm{L}$ sulfate and $90 \mathrm{mg} / \mathrm{L}$ sodium), $1 \mathrm{~L}-3$ (310 $\mathrm{mg} / \mathrm{L}$ sulfate and $115 \mathrm{mg} / \mathrm{L}$ sodium), and $2 \mathrm{~L}-3$ (290 $\mathrm{mg} / \mathrm{L}$ sulfate and $95 \mathrm{mg} / \mathrm{L}$ sodium)] near the contact with the Chadron and Lance Formations.

Ground-water-quality data from water near bedrock support the water-level data and age dating of the water (Verstraeten and others, 2000), suggesting ground-water flow from the bedrock into the alluvial aquifer. In the northern alluvial aquifer, water moves generally from north to south, and ground water from the Brule aquifer mixes with younger alluvial ground water. In the southern alluvial aquifer on the south side of the North Platte River, ground water moves from the southwest to the northeast, and some older water from the Chadron aquifer mixes with younger water from the alluvial aquifer.

During base flow and during the winter when spring melt water is absent and precipitation generally is minimal, surface water from the North Platte River at Morrill had an intermediate composition between the ground water in the Brule aquifer and ground water in the Chadron and Lance aquifers on the basis of sulfate and chloride data. As a generally gaining stream, the North Platte River receives water from runoff where the eroded Lance Formation is exposed outside the study area and receives water through underflow from the alluvial aquifer and from the Brule, Chadron, and Lance aquifers. During snowmelt in the spring, water in the North Platte River mainly comes from areas upstream in Wyoming, which results in a different water chemistry. Specifically, specificconductance values and calcium, magnesium, and sulfare concentrations tend to be larger during this time than during the remainder of the year.

Surface water from the Interstate Canal had a distinct signature with small calcium, magnesium, chloride, and silica concentrations. Surface water from the Tri-State Canal was similar to the chemistry of water from the North Platte River at the State line and was intermediate between the chemical composition of surface water from the Interstate Canal and from the North Platte River at Morrill. 


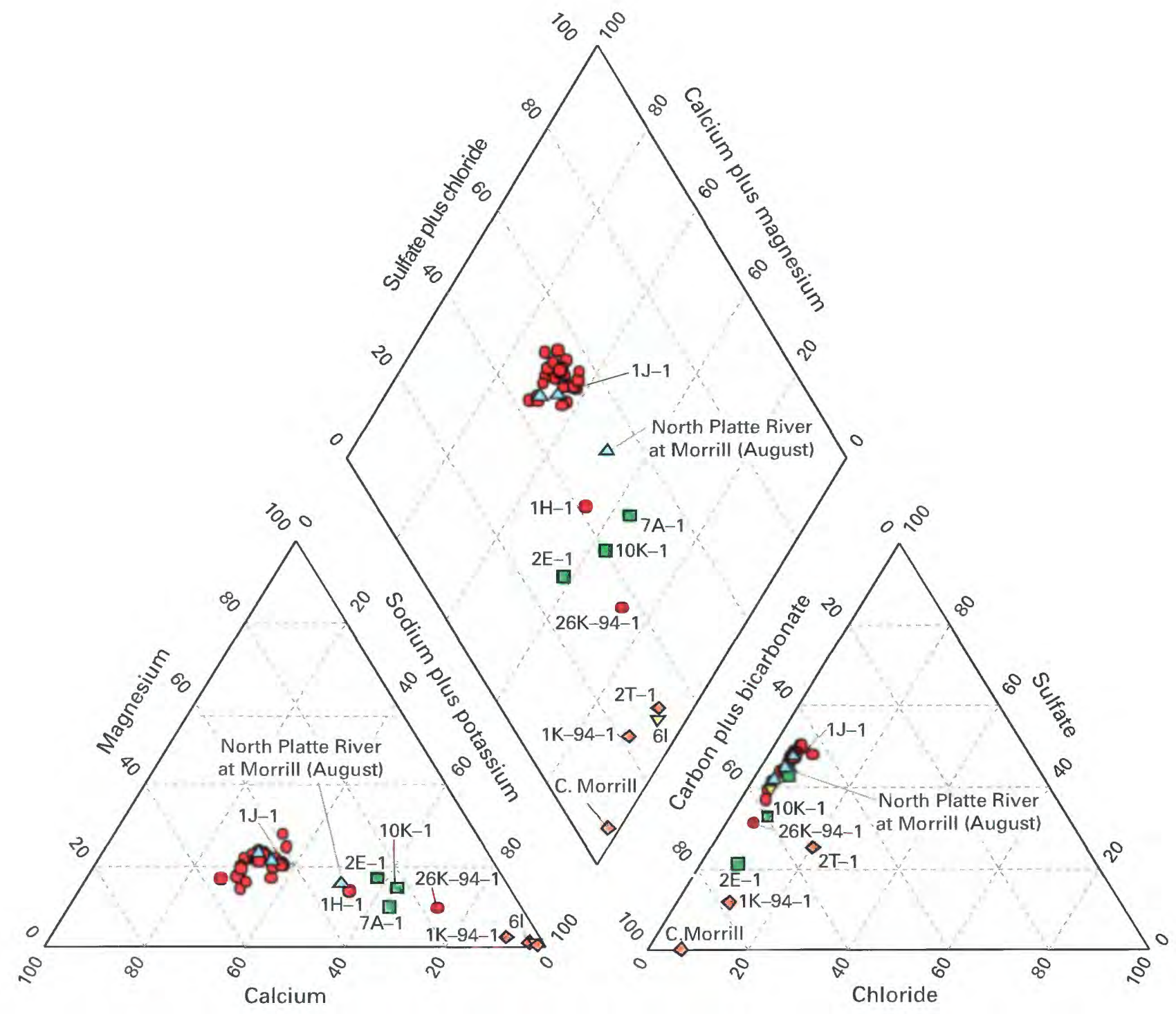

Percentage of milliequivalents per liter

\section{EXPLANATION}

$\begin{array}{lc}\Delta \text { Surface water } & \diamond \text { Chadron aquifer } \\ \text { - Alluvial aquifer } & \nabla \text { Lance aquifer } \\ \square \text { Brule aquifer } & 2 T-1 \text { Site identification }\end{array}$

Figure 14. Ionic composition of water from selected surface-water and ground-water sampling sites along geologic section $B-B^{\prime}$, Dutch Flats area, summer 1998.

\section{Nitrogen}

Nitrogen species analyzed during the study included nitrate, nitrite, ammonia, organic nitrogen, and nitrogen gas (Verstraeten and others, in press). Although fertilizer is applied to the land in the form of ammonia, it generally is transformed to nitrate through oxidation in the unsaturated zone. Nitrate is transported to the water table with recharge after precipitation, transported along flow paths through the aquifer, and then, in part, discharged into surface water.

In surface water, the maximum observed nitrate concentration was $11 \mathrm{mg} / \mathrm{L}$ in surface water from Akers Draw (site SW10), a spring discharging water 
from the alluvial aquifer. Water from Sheep Creek (site SW8) contained nitrate concentrations of as much as $7.6 \mathrm{mg} / \mathrm{L}$. Nitrate concentrations in water from the North Platte River at Morrill (site SW9), generally remained less than $3.0 \mathrm{mg} / \mathrm{L}$. The largest nitrate concentrations in the North Platte River generally were observed during the winter months from December through February. During the summer months (June, July, and August), nitrate at times remained undetected in water from the North Platte River at Morrill. During the irrigation season (June through September), nitrate concentrations generally were undetected in water from the Interstate Canal. In 1998, the maximum nitrate concentrations during the summer months were observed in water from Akers Draw (site SW 10) at $9.1 \mathrm{mg} / \mathrm{L}$ and from Sheep Creek (site SW8) at $6.1 \mathrm{mg} / \mathrm{L}$ (fig. 15).

In ground water, a stratification of nitrate was observed, with larger concentrations (at times exceeding $20 \mathrm{mg} / \mathrm{L}$ ) in shallow water less than 5 years old, mainly from the alluvial aquifer, and small concentrations (less than $0.05 \mathrm{mg} / \mathrm{L}$ ) in deep water older than 20 years, especially in water from the Chadron aquifer (figs. 15, 16, and 17) (Verstraeten and others, 2000). Concentrations as large as $28 \mathrm{mg} / \mathrm{L}$ in water from well $1 \mathrm{~F}-1$ in $1997,27 \mathrm{mg} / \mathrm{L}$ in water from well $1 \mathrm{~J}-3$ in $1997,24 \mathrm{mg} / \mathrm{L}$ in water from well $10 \mathrm{E}-2$ in 1998 , and $24 \mathrm{mg} / \mathrm{L}$ in water from well $2 \mathrm{~F}-3$ in 1998 (fig. 15) were detected; all four wells are shallow wells completed in the alluvial aquifer. Nitrate concentrations less than $2.0 \mathrm{mg} / \mathrm{L}$ were observed locally in shallow ground water: (1) near wetlands and near the North Platte River, where ground-water levels were shallow and ground water was depleted of dissolved oxygen; (2) in places near the contact with shallow bedrock; and (3) near the canals during the irrigation season and, to a lesser extent, near laterals where recharge through seepage of surface water to the aquifer was evident (figs. 15 and 16).

A direct relation exists between fertilizer use and nitrate concentration over time in the alluvial aquifer. Fertilizer use increased by a factor of about 15 from 1950 through 1994 (fig. 4). Nitrate concentrations in ground water from the alluvial and Brule aquifers also increased during this time frame (Verstraeten and others, 2000).

Increases in nitrate concentrations have been observed near Oshkosh, Nebraska, 70 to $95 \mathrm{mi}$ downstream from the study area (Exner and Spalding, 1994) (index map, fig. 1). On the basis of $\delta^{15} \mathrm{~N}^{-N_{3}}{ }^{-}$(a nitrogen isotope), Exner and Spalding (1994) determined that nitrate in water from the shallow aquifer near Oshkosh mainly was derived from commercial fertilizer rather than animal waste. In the Dutch Flats area along transect $B-B^{\prime}$, the $\delta^{15} \mathrm{~N}_{-} \mathrm{NO}_{3}{ }^{-}$in ground water ranged from -0.5 per mil (per thousand) to 11.5 per mil (Verstraeten and others, 2000). Most terrestrial materials have a composition of $\delta^{15} \mathrm{~N}_{-\mathrm{NO}_{3}}{ }^{-}$ between -20 and +30 per mil. Atmospherically derived nitrogen and fertilizer-derived nitrogen typically have $\delta^{15} \mathrm{~N}$ values less than 6 per mil, whereas animal-derived nitrogen has $\delta^{15} \mathrm{~N}$ values more than 9 per mil (Gormly and Spalding, 1979; Exner and Spalding, 1994; McMahon and others, 1999). The $\delta^{15} \mathrm{~N}$ values of less than 6 per mil are consistent with other occurrences of nitrate contamination beneath fertilized fields (Verstraeten and others, 2000). Locally, however, ground water has been affected by nitrogen from animal waste or a mixture of both sources.

During the summers of 1998 and 1999, the median nitrate concentration in water samples from the alluvial aquifer was $4.3 \mathrm{mg} / \mathrm{L}$ (116 samples). Concentrations ranged from less than 0.05 to $24 \mathrm{mg} / \mathrm{L}$. In water from the Brule aquifer, nitrate concentrations varied from 0.23 to $11 \mathrm{mg} / \mathrm{L}$ with a median of $5.0 \mathrm{mg} / \mathrm{L}$ (18 samples). The USEPA MCL of $10 \mathrm{mg} / \mathrm{L}$ (U.S. Environmental Protection Agency, 2000) was exceeded in 17 of 116 samples ( 15 percent) from all wells completed in the alluvial aquifer and in 11 of 48 samples ( 23 percent) from shallow wells completed in the alluvial aquifer. Nitrate concentrations in water from the Chadron aquifer varied from less than 0.05 to $8.4 \mathrm{mg} / \mathrm{L}$ (four samples). Water from well 6I, completed in the Lance aquifer, had a nitrate concentration of $7.0 \mathrm{mg} / \mathrm{L}$ in the summer of 1998 (fig. 15).

Well $1 \mathrm{C}-4$, completed at a depth similar to well $1 \mathrm{C}-3$ (table 2), was constructed near a lateral to evaluate whether shallow ground water near a lateral would have different water chemistry depending upon the proximity of the lateral to the well. Water from well $1 \mathrm{C}-4$ was sampled 29 times generally within 1 hour of when water from well $1 \mathrm{C}-3$ was sampled. Samples from these two wells were analyzed for nitrate ( 24 samples) and other constituents. Large differences were observed between nitrate concentrations in water from shallow ground water obtained from these wells. Differences in nitrate concentrations ranged from 0.26 to $5.5 \mathrm{mg} / \mathrm{L}$, with a median difference of $1.7 \mathrm{mg} / \mathrm{L}$. Relative differences in nitrate 


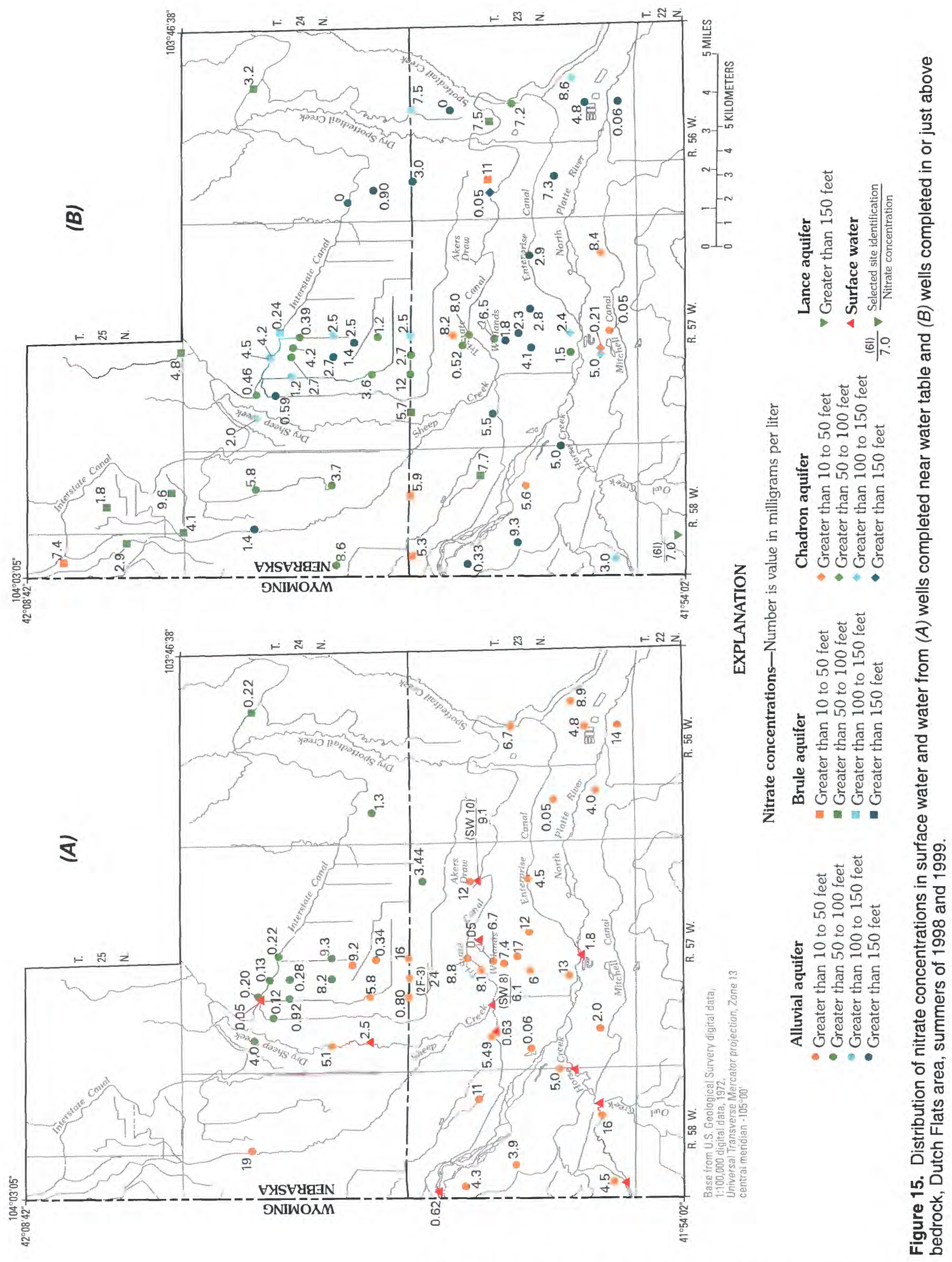




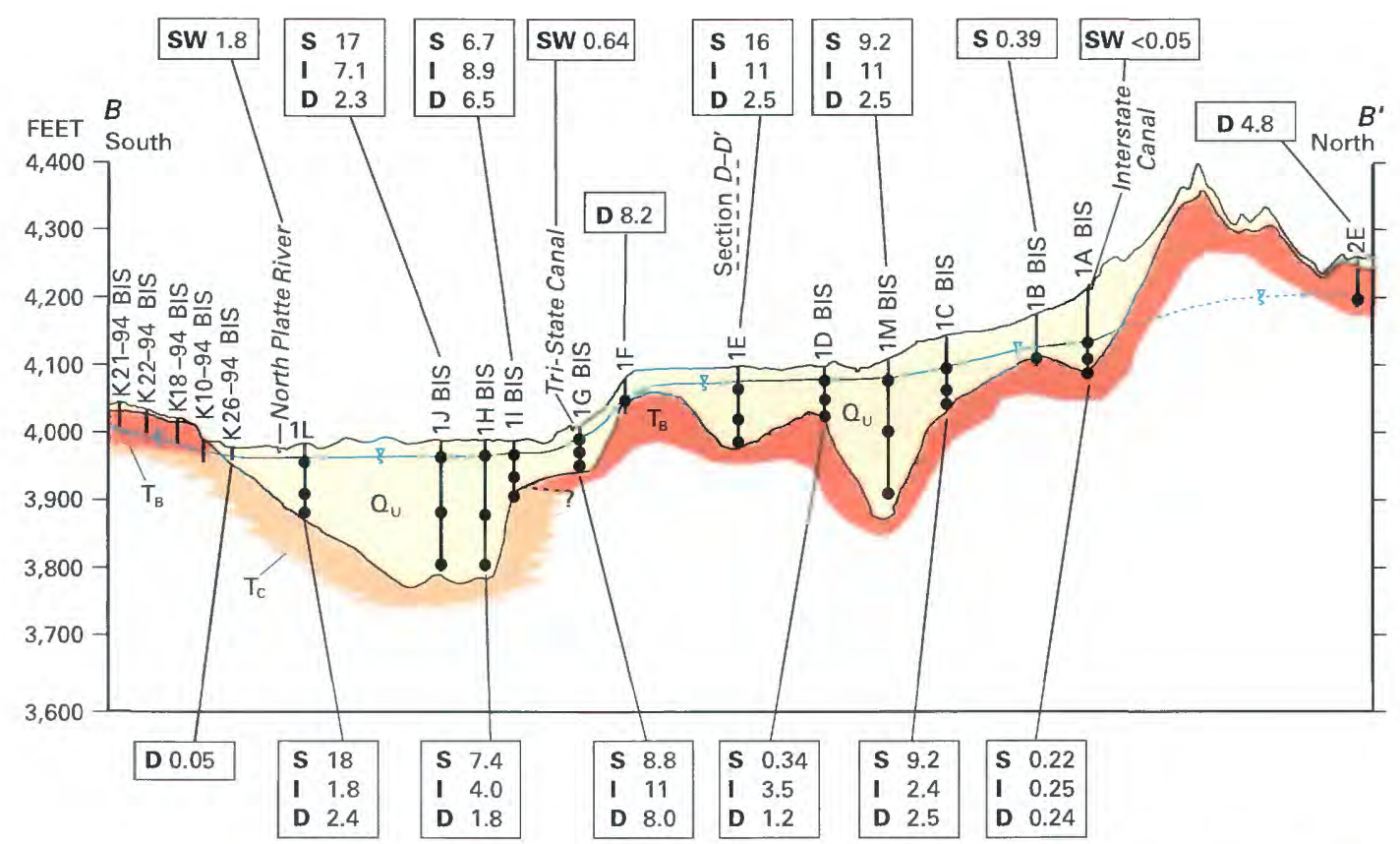

Vertical scale greatly exaggerated Datum is sea level

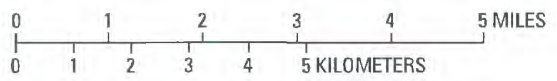

\section{EXPLANATION}

\begin{tabular}{|c|c|}
\hline $\mathrm{Q}_{u}$ & Alluvial and eolian deposits \\
\hline$T_{B}$ & $\begin{array}{l}\text { Brule Formation of the } \\
\text { White River Group }\end{array}$ \\
\hline $\mathrm{T}_{\mathrm{c}}$ & $\begin{array}{l}\text { Chadron Formation of the } \\
\text { White River Group }\end{array}$ \\
\hline & Undifferentiated bedrock \\
\hline & Geologic contact \\
\hline
\end{tabular}

\author{
Water table-Dashed where estimated \\ BIS Bend in section \\ $§-$ Well and identification number \\ -Location of well screen (not to scale) \\ s Water from shallow well \\ I Water from intermediate well \\ D Water from deep well \\ sw Surface water \\ $<$ Less than
}

Numbers in boxes indicate nitrate concentrations, in milligrams per liter

Figure 16. Generalized geologic section $B-B^{\prime}$ showing nitrate concentrations, Dutch Flats area, summer 1998. Locations of sampling sites are shown in figure 8.

concentrations of water collected within 1 hour from wells $1 \mathrm{C}-3$ and $1 \mathrm{C}-4$ varied from 4 to 55 percent with a median difference of 19 percent. These results indicate that nitrate concentrations in shallow ground water can vary as much as $5 \mathrm{mg} / \mathrm{L}$ over short distances because of seepage of surface water containing small nitrate concentrations from the laterals to the ground water. No denitrification was apparent at these sites.
The occurrence of nitrite, ammonia, and nitrogen gas was limited in surface-water and ground-water samples. In surface water, nitrite and ammonia concentrations generally were near or less than the reporting level. The maximum concentrations were $0.08 \mathrm{mg} / \mathrm{L}$ nitrite as $\mathrm{N}$ in water from the North Platte River at Morrill (site SW9) and $0.06 \mathrm{mg} / \mathrm{L}$ ammonia as $\mathrm{N}$ in water from Sheep Creek (site SW8) (summer 


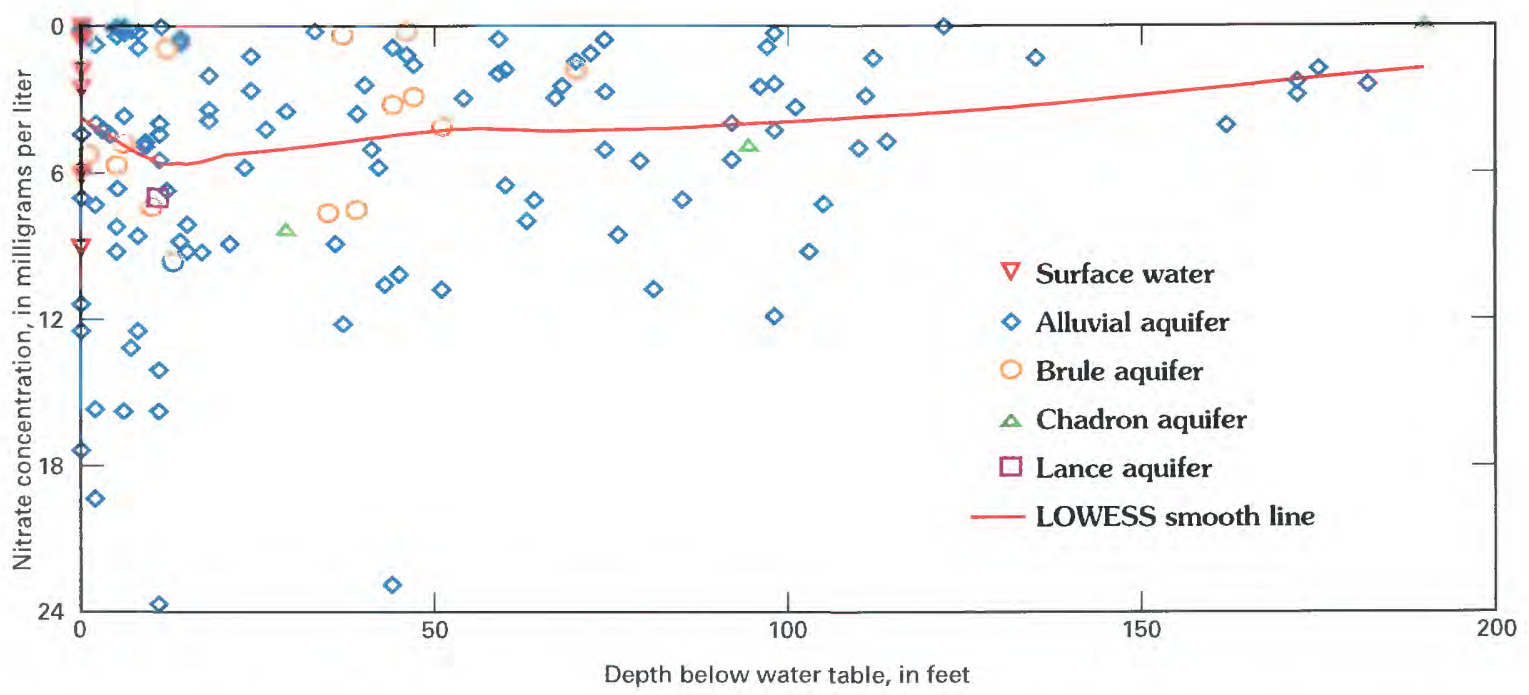

Figure 17. Distribution of nitrate concentrations by depth below water table, Dutch Flats area, summer 1998.

1998). Because the water in the river tends to be aerobic, most nitrite and ammonia apparently oxidized readily to nitrate. Because the North Platte River is mostly a gaining stream, it is conceivable that part of the nitrate load in the river, especially during low stages, might be the result of contributions of shallow ground water with elevated nitrate concentrations. Surface-water sampling sites with large nitrate concentrations, Sheep Creek (site SW8) and Akers Draw (site SW10), generally had a large ground-water component (estimated at nearly 100 percent) from shallow water in the alluvial aquifer.

At places, detectable nitrite and ammonia concentrations, as well as dissolved organic matter, were present in ground water. For example, a water sample from well $26 \mathrm{~K}-94-1$ contained as much as $21 \mathrm{mg} / \mathrm{L}$ dissolved nitrogen gas, $0.92 \mathrm{mg} / \mathrm{L}$ ammonia, and 0.58 dissolved organic matter as $\mathrm{N}$ in the summer of 1998. Nitrate or nitrite concentrations were not detected in this sample. In ground water in the southern alluvial aquifer near the base of the sediment or near the contact with the Chadron and Lance Formations, dissolved-oxygen concentrations were zero.

Nitrite generally was not present in shallow ground water near the water table, indicating that denitrification generally is not an important process in the alluvial aquifer. However, on the basis of dissolvedgas data, including nitrogen, oxygen, and methane $\left(\mathrm{CH}_{4}\right)$ gases, some evidence for denitrification may exist near the contact with bedrock (wells $1 \mathrm{H}-1$, $1 \mathrm{~L}-1$, and 26K-94-1) or in the Chadron aquifer (wells 1K-94-1 and C. Morrill) (Verstraeten and others, 2000; Verstraeten and others, in press).
Methane was present in ground water from the Chadron aquifer near wells $2 \mathrm{~T}-1,1 \mathrm{~K}-94-1,26 \mathrm{~K}-94-1$, and C. Morrill. The odor of hydrogen sulfide $\left(\mathrm{H}_{2} \mathrm{~S}\right)$ was detected during sampling at these sites.

Denitrification has been identified along the South Platte River in northeastern Colorado (McMahon and others, 1999). McMahon and others (1999) reported that the Pierre Shale was a sink for a minor fraction of nitrate in the alluvial aquifer transported by diffusion into the shale through denitrification. They suggested that, if advection was the dominant process, the fraction of nitrate lost to denitrification might have been large. More detailed work would be useful in identifying the specific reactions that occur near the redoxcline along the North Platte River.

\section{Uranium, Radon, and Uranium Activity Ratio}

Uranium occurs in solution, primarily as $5+$ and $6+$ species, in an oxidizing environment with $\mathrm{pH}$ similar to those observed in the study area (7.0 to 9.0) (Maynard, 1983, p. 151-156). Solubility of uranium also is enhanced when it forms carbonate and phosphate complexes. Uranium ( $6+$ species) can become adsorbed to solid organic matter or clay (Langmuir, 1978). Most materials such as mudstone, shale, and sandstone in the White River Group (Brule and Lance Formations) contain traces of uranium in the Dutch Flats area. The playa facies of the Brule Formation near Chadron, Nebraska (fig. 1), is an excellent example of a lithologic facies containing trace amounts of 
uranium (Dickinson, 1990). The most common primary minerals of uranium are uraninite $\left(\mathrm{UO}_{2}\right)$ and coffinite $\left(\mathrm{USiO}_{4}\right)$. Uranium also is associated with phosphate fertilizer (Snow and Spalding, 1994).

Uranium and radon concentrations varied substantially in the Dutch Flats area. Uranium concentrations in surface water were flow and time dependent. Uranium concentrations generally were larger in samples from the North Platte River at Morrill $(22 \mu \mathrm{g} / \mathrm{L}$, site SW9) than in samples from the North Platte River at the Wyoming-Nebraska State line $(13 \mu \mathrm{g} / \mathrm{L}$, site SW2) in August 1999 (figs. 18 and 19). Uranium concentrations in water from the North Platte River at Morrill (site SW9) varied from 11 to $31 \mu \mathrm{g} / \mathrm{L}$. At the State line, uranium concentrations in water from the North Platte River were less than $13 \mu \mathrm{g} / \mathrm{L}$. Smaller concentrations of uranium ( $7.9 \mu \mathrm{g} / \mathrm{L}$, site SW 1) were detected in water from the Interstate Canal (fig. 18). The largest uranium concentrations $(44 \mu \mathrm{g} / \mathrm{L})$ generally were measured in water from Owl Creek near Lyman (site SW5). Uranium concentrations in water from Horse Creek near the State line (site SW4) were about $2.5 \mu \mathrm{g} / \mathrm{L}$ less than at the site near Lyman (site SW6) on August 23, 1999.

During high-flow conditions in the spring and early summer, uranium is diluted in the river by snowmelt water, occasionally supplemented by water from thunderstorms. During those times, uranium concentrations were less than $30 \mu \mathrm{g} / \mathrm{L}$ in samples from the North Platte River at Morrill (site SW9). However, during the late fall and winter from November until February, uranium concentrations in samples from the North Platte River at Morrill peaked at $31 \mu \mathrm{g} / \mathrm{L}$. Additional investigations are currently (2001) underway to identify the sources of uranium in the surface water.

In ground water, uranium concentrations also varied considerably (figs. 18 and 19). Uranium concentrations in the alluvial aquifer varied from about $2.0 \mu \mathrm{g} / \mathrm{L}$ (water from well $2 \mathrm{~F}-3$ ) in shallow ground water in the northern alluvial aquifer to about $80 \mu \mathrm{g} / \mathrm{L}$ (water from well 9E-2) in the basal southern alluvial aquifer (fig. 18). As much as $88 \mu \mathrm{g} / \mathrm{L}$ of uranium (water from well 1K-94-2) was present in shallow ground water near the North Platte River and as much as $89 \mu \mathrm{g} / \mathrm{L}$ (water from well $9 \mathrm{E}-1$ ) in ground water near the contact with the Chadron and Lance aquifers (fig. 18). The median uranium concentration in the alluvial aquifer was $16 \mu \mathrm{g} / \mathrm{L}$. Seventeen of $121 \mathrm{sam}-$ ples (14 percent) from wells completed in the alluvial aquifer exceeded the USEPA MCL of $30 \mu \mathrm{g} / \mathrm{L}$
(U.S. Environmental Protection Agency, 2000). Uranium concentrations of as much as $88 \mu \mathrm{g} / \mathrm{L}$ were detected in water samples from the alluvial aquifer near the contact with the Chadron aquifer. As much as $33 \mu \mathrm{g} / \mathrm{L}$, exceeding the USEPA MCL for uranium, was detected in water from well $7 \mathrm{G}-1$ completed in the Brule aquifer. As much as $71 \mu \mathrm{g} / \mathrm{L}$ of uranium were detected in a sample from well 6 completed in the Lance aquifer (fig. 18). Water in the Chadron aquifer, especially at depth, had concentrations of uranium that ranged from less than $0.07 \mu \mathrm{g} / \mathrm{L}$ (water from well C. Morrill) because water was depleted of oxygen, which caused uranium to remain precipitated in this environment, to $89 \mu \mathrm{g} / \mathrm{L}$ (water from well 9E-1) in an oxygenated environment (fig. 18). Water from two of six wells completed in the Chadron aquifer exceeded the USEPA MCL of $30 \mu \mathrm{g} / \mathrm{L}$. During the irrigation season near the irrigation canals, uranium concentrations in ground water decreased to less than $10 \mu \mathrm{g} / \mathrm{L}$, concentrations similar to those of water from the Interstate and Tri-State Canals (about 6.0 to $8.0 \mu \mathrm{g} / \mathrm{L}$ ) (Verstraeten and others, 2000).

Radon-222 is a daughter product of uranium with a short half-life and a tendancy to be enhanced by water from or near bedrock rich in uranium. USEPA has proposed an MCL of $300 \mathrm{pCi} / \mathrm{L}$ and an alternative MCL (AMCL) of 4,000 pCi/L (U.S. Environmental Protection Agency, 2000), which can be adopted by a State. Radon activities in surface water tended to be small (less than $80 \mathrm{pCi} / \mathrm{L}^{222} \mathrm{Rn}$ ) because radon readily volatilizes when exposed to the atmosphere (figs. 20 and 21). Volatilization was not as important for surface-water samples from Akers Draw (as much as $420 \mathrm{pCi} / \mathrm{L}$, site SW10), Sheep Creek (as much as $120 \mathrm{pCi} / \mathrm{L}$, site SW8), Dry Sheep Creek (as much as $133 \mathrm{pCi} / \mathrm{L}$, site SW7), and the wetlands site (as much as $160 \mathrm{pCi} / \mathrm{L}$, site $S W 11$ ). These data reflect the fact that surface water at these sites recently consisted mostly of ground-water discharge. About $6,100 \mathrm{ft}$ upstream from the sampling site at Akers Draw, ground water is discharged intermittently to the surface.

Ninety-four of 117 samples ( 80 percent) collected from wells completed in the alluvial aquifer had radon activities less than $300 \mathrm{pCi} / \mathrm{L}$. A radon activity of $1,699 \mathrm{pCi} / \mathrm{L}$ was detected in water from well $1 \mathrm{G}-1$ (figs. 20 and 21). The largest radon activity $(4,190 \mathrm{pCi} / \mathrm{L})$ was measured in water from well $1 \mathrm{~K}-94-1$ completed in the Chadron aquifer (fig. 20). Radon activities in excess of $1,000 \mathrm{pCi} / \mathrm{L}$ 


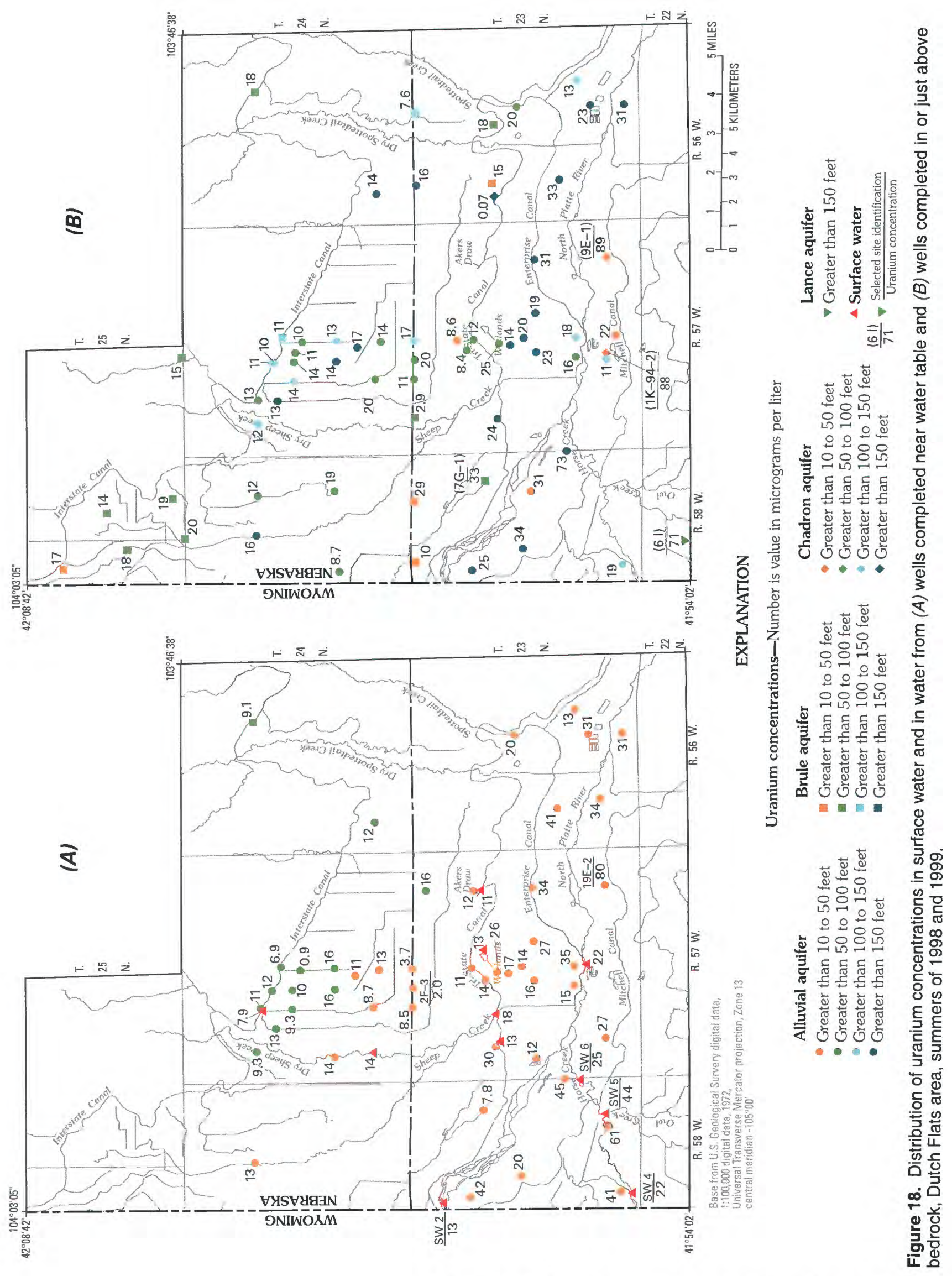




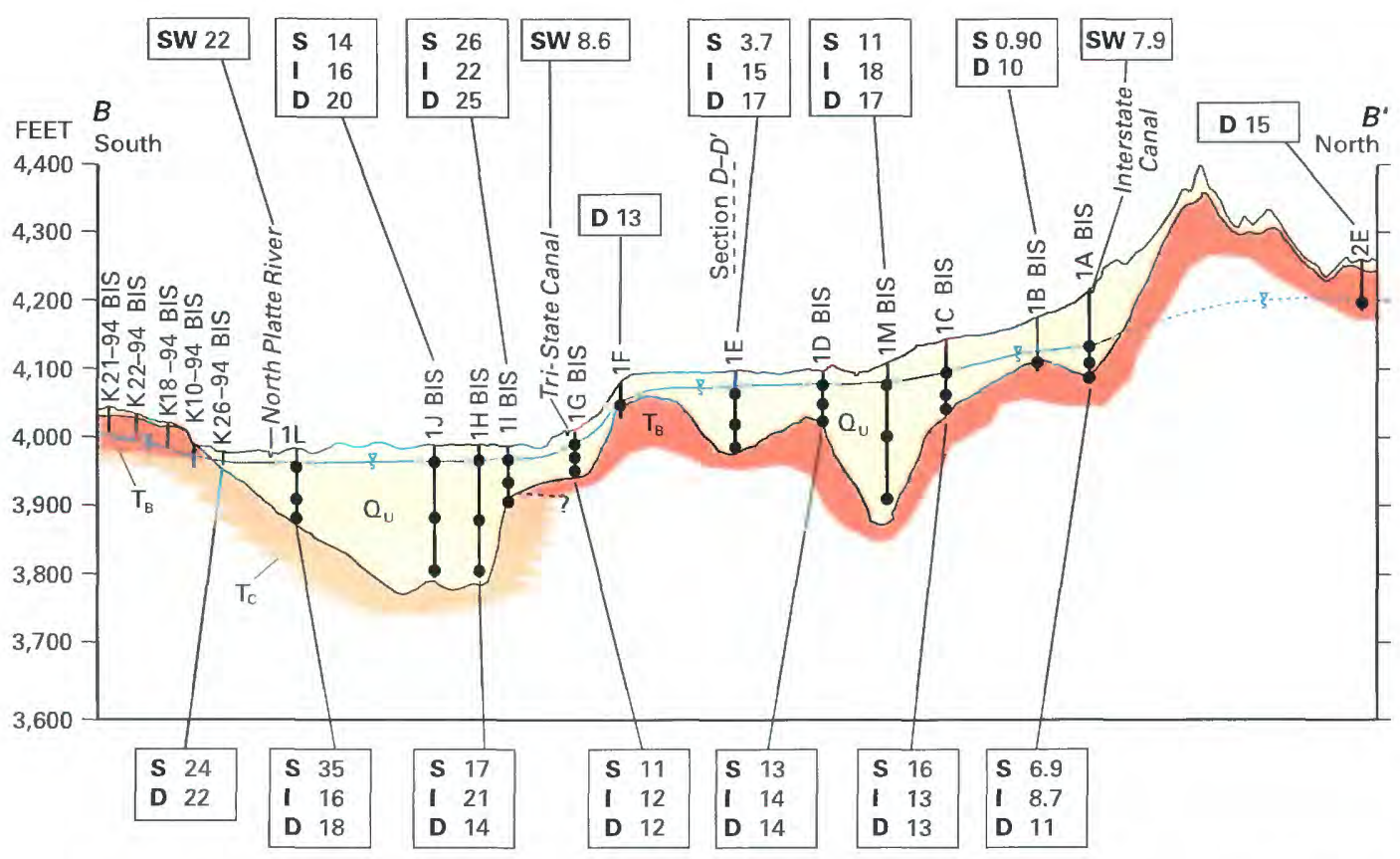

Vertical scale greatly exaggerated Datum is sea level

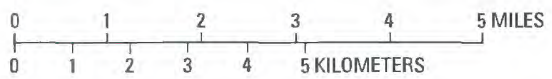

\section{EXPLANATION}

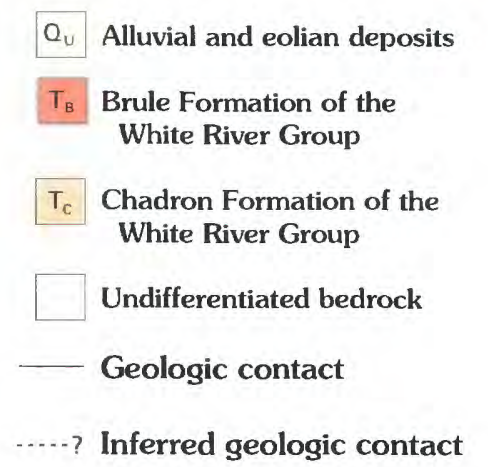

\begin{abstract}
-... Water table-Dashed where estimated
BIS Bend in section

$\$-$ Well and identification number

- Location of well screen (not to scale)

s Water from shallow well

I Water from intermediate well

D Water from deep well

sw Surface water
\end{abstract}

Numbers in boxes indicate uranium concentrations, in micrograms per liter

Figure 19. Generalized geologic section $B-B^{\prime}$ showing uranium concentrations, Dutch Flats area, summers of 1998 and 1999.

(fig. 20) are present in the northwest part of the study area where wells are completed in the Brule aquifer (fig. 20). Water from 15 of 16 wells (94 percent) completed in the Brule aquifer exceeded $300 \mathrm{pCi} / \mathrm{L}$, and water from 5 of 16 wells ( 31 percent) completed in the Brule aquifer exceeded $1,000 \mathrm{pCi} / \mathrm{L}$. Wells completed in the Chadron aquifer had large ranges in radon activities $(493 \mathrm{pCi} / \mathrm{L}$ in water from well $1 \mathrm{~L}-1$ to $4,190 \mathrm{pCi} / \mathrm{L}$ in water from well $1 \mathrm{~K}-94-1)$. Overall, uranium concentrations and radon activities indicate that water in the alluvial aquifer consists partly of water that has moved from the Brule, Chadron, or Lance aquifers.

The uranium activity ratio $\left({ }^{234} \mathrm{U} /{ }^{238} \mathrm{U}\right)$ or UAR varied among surface-water and ground-water samples (Verstraeten and others, 2000). The UAR in water from the North Platte River at the Wyoming-Nebraska State line (site SW2) was 1.6 (fig. 22). In water from the North Platte River at Morrill (site SW9), the UAR was 1.7 , and the UAR in water from Horse Creek at 


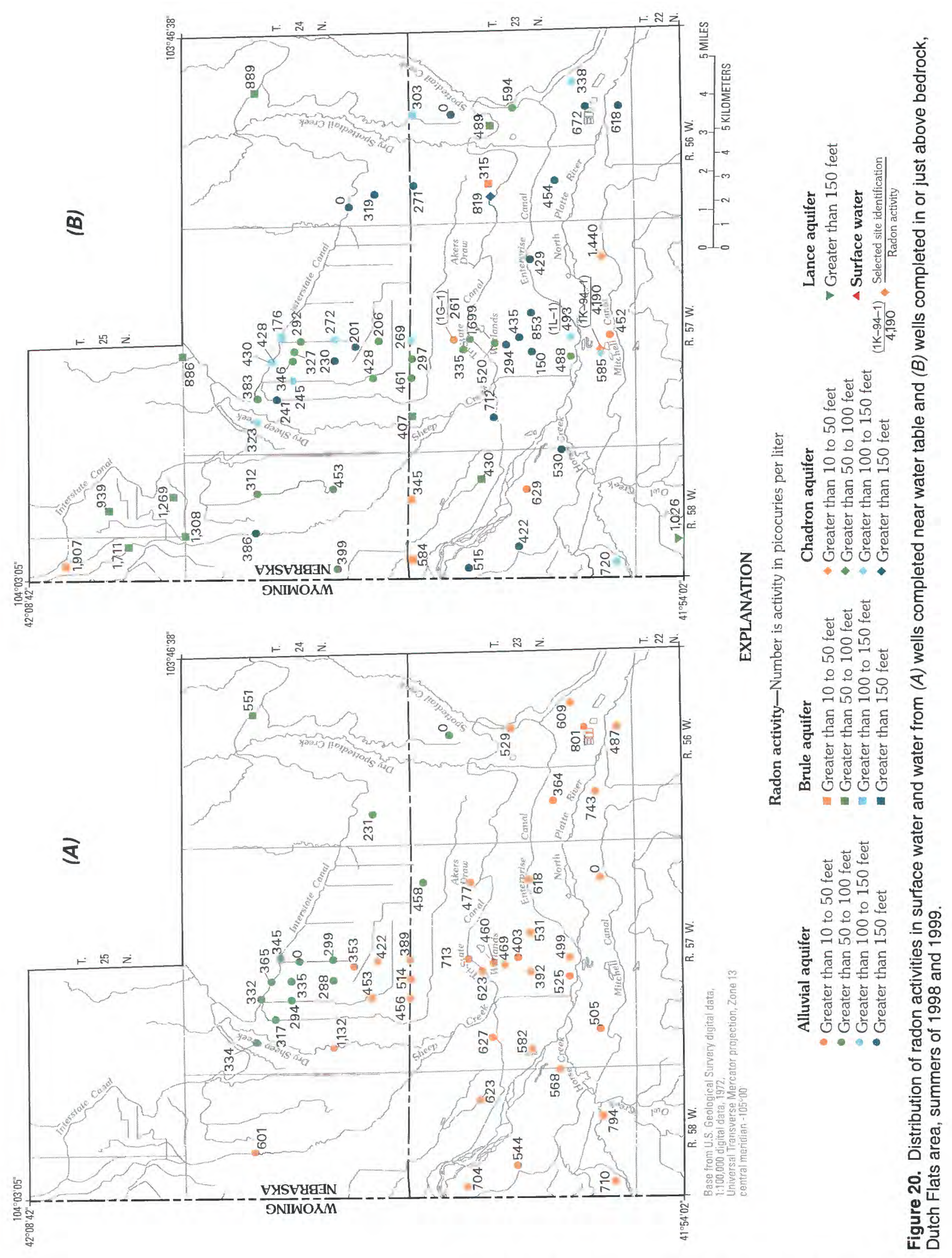




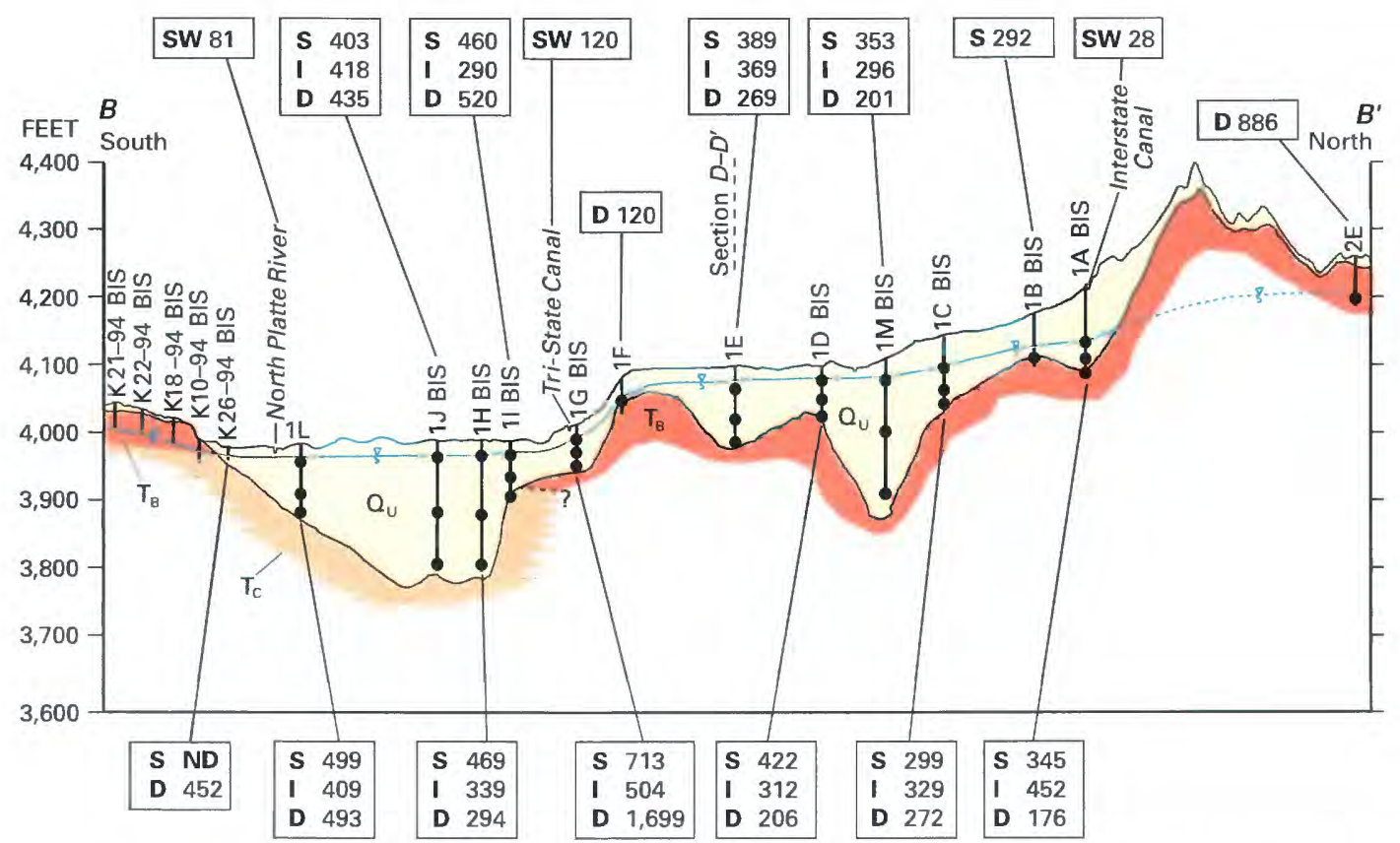

Vertical scale greatly exaggerated Datum is sea level

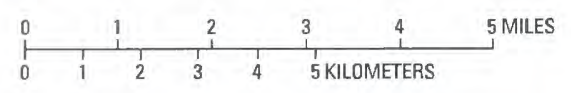

\section{EXPLANATION}

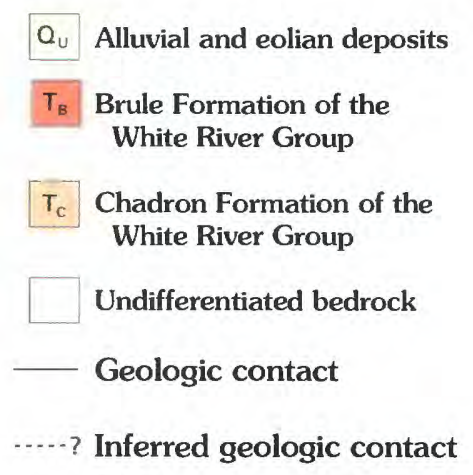

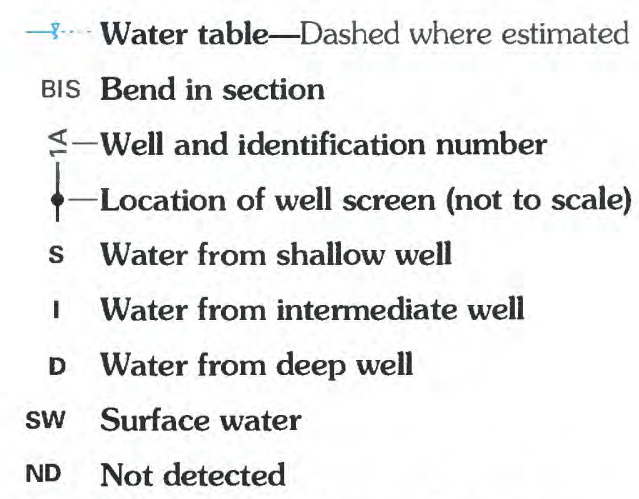

Numbers in boxes indicate radon activity, in picocuries per liter

Figure 21. Generalized geologic section B-B' showing radon activities, Dutch Flats area, summer 1998.

Lyman (site SW6) was 1.8 (figs. 22 and 23). The UAR generally varied from 1.2 (water from well $2 \mathrm{~F}-3$ ) to 2.1 (water from well $2 \mathrm{~A}-1$ ) in water from the alluvial aquifer and varied from 1.6 (water from well $1 \mathrm{~A}-1$ ) to 2.3 (water from well $7 \mathrm{~A}-1$ ) in water from the Brule aquifer. Large UARs in water from the alluvial aquifer (maximum 2.2 in water from well $2 \mathrm{~F}-1$ ) were detected at depth near the contact with the Brule Formation. Small UARs in water from the alluvial aquifer were detected in shallow water (1.2 in water from well $2 \mathrm{~F}-3$ ). The UAR appeared variable in water from the Chadron aquifer, from 1.3 (water from well 9E-1) to 2.0 (water from well 2T-1).

Fractionation of ${ }^{234} \mathrm{U}$ from ${ }^{238} \mathrm{U}$, resulting in radioactive disequilibria (UARs different than 1.0), 


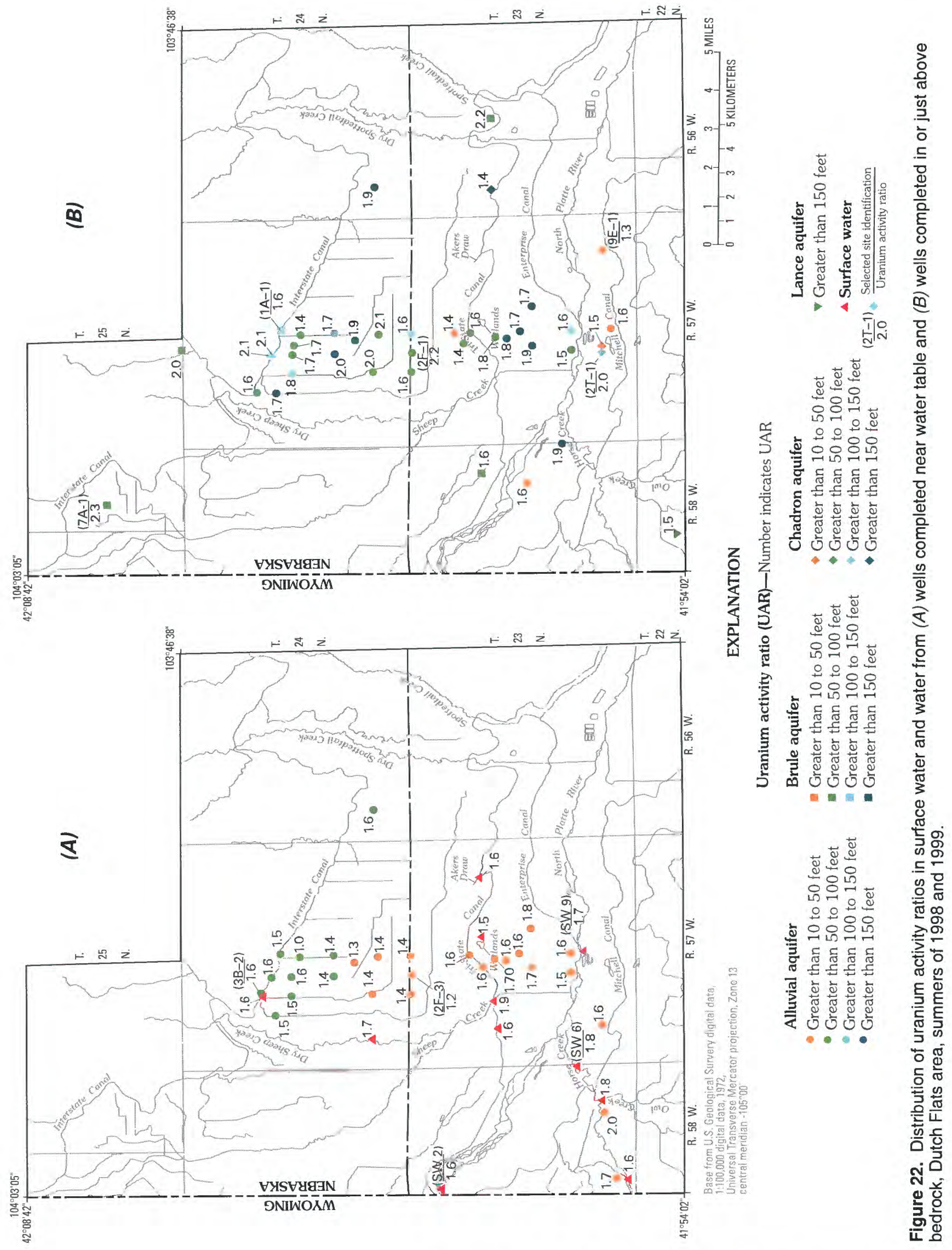




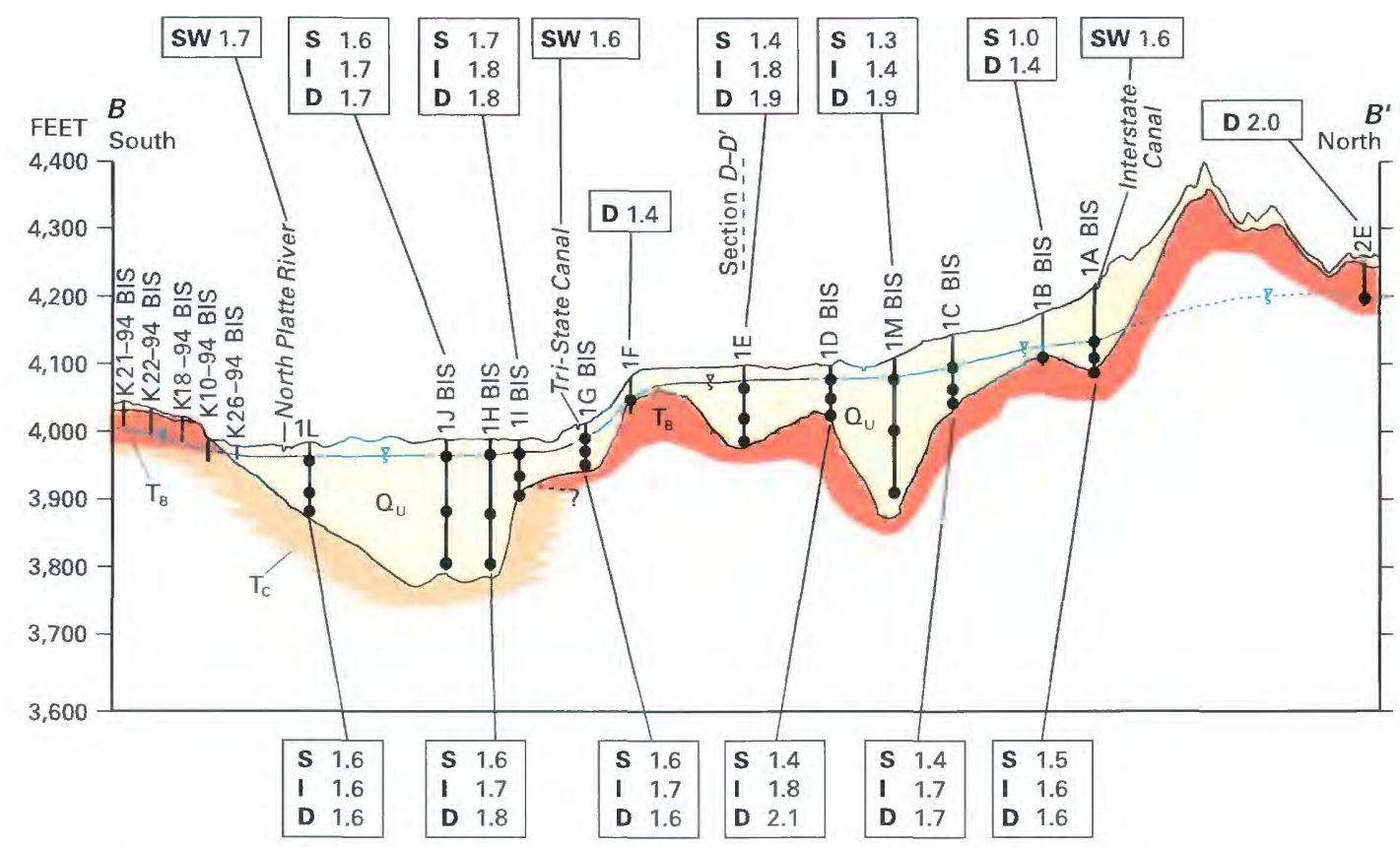

Vertical scale greatly exaggerated

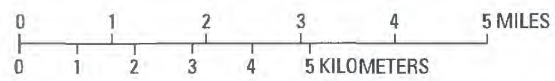

\section{EXPLANATION}

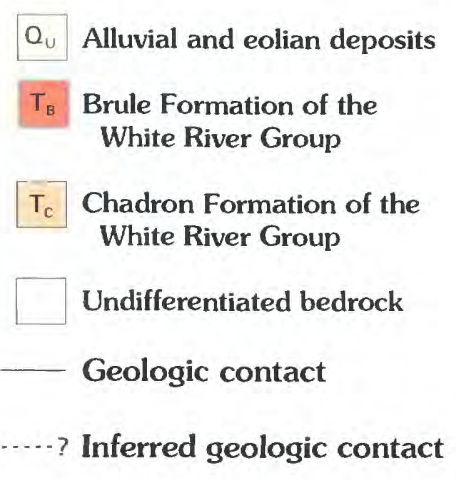

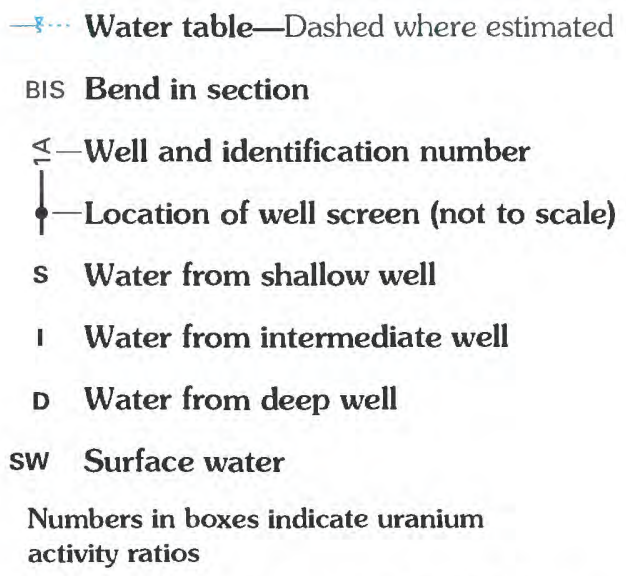

Figure 23. Generalized geologic section $B-B^{\prime}$ showing uranium activity ratios, Dutch Flats area, summers of 1998 and 1999.

gives rise to variable UAR signatures dependent upon the source of the water. The longer the contact time with rocks or sediment containing uranium minerals, the more chance for fractionation and creation of UARs larger than 1.0 (Snow and Spalding, 1994). Therefore, UARs in surface water under high-flow conditions are expected to have UARs closest to equilibrium (UAR equal to 1.0) compared to water in allu- vial sediment with moderate residence times and water in shale bedrock with long residence times (UAR greater than 2.0). Additional investigations are being performed to evaluate these differences, to determine the sources of uranium, and to evaluate sources of uranium-containing water. 


\section{INTERACTION OF SURFACE AND GROUND WATER IN SELECTED AREAS}

Interaction of surface and ground water have been shown to be of significant concern (Winter and others, 1998). Contaminated ground water that discharges to surface-water systems can result in long-term contamination of surface water. Contaminated surface water also can be a major source of contamination to aquifers depending on the flow regime of the surface water. Historically in Nebraska, the interaction of surface and ground water has not been considered in the implementation of water-management practices because the hydraulic connection between surface and ground water was unknown. This section elaborates on the physical and chemical interaction of the North Platte River, the canals, and the ground water in the Dutch Flat area.

\section{Physical Interaction}

The ability of water to move between the stream and the aquifer through the streambed is the driving force of surface-water/ground-water interaction. If water cannot move through the streambed or bank, then no interaction of water between one system and the other can occur. The direction of the water movement generally depends on local or regional stresses on the systems. In addition, it is not uncommon for direction of movement to change seasonally (Winter and others, 1998).

In the Dutch Flat area, two prominent types of surface-water features-one manmade and the other natural-control the surface-water/ground-water interaction. The two primary canals-Interstate and TriState Canals-contribute substantial amounts of recharge to the alluvial aquifer, and this aquifer, in turn, generally discharges to the North Platte River. Surface water moving downward through the beds of the two canals affects the movement of ground water in the study area by increasing hydraulic heads in the aquifer. The highest water-level altitudes were observed near the Interstate Canal (fig. 12, well 1A-3), and the lowest ones were observed near the North Platte River (fig. 12, well $1 \mathrm{~K}-3$ ).

Most of the monitoring wells in the northern alluvial aquifer and the northern part of the southern alluvial aquifer experienced water-level rises during the summer months. Water levels in monitoring wells $1 \mathrm{~L}-3$ (fig. 12), $2 \mathrm{~L}-3$, and $8 \mathrm{E}$ in the southern part of the southern alluvial aquifer showed the effects of bank storage from spring flooding of the North Platte River. Water levels in monitoring wells in the north rern alluvial aquifer rose (fig. 12, wells $1 \mathrm{~A}-3$ and $2 \mathrm{~A}-1$ ) under the effects of seepage from surface-water irrigation systems. Water levels in monitoring wells in the northern part of the southern alluvial aquifer rose (fig. 12, for example well 1G-3) under the effects of seepage from both the Tri-State Canal and movement of ground water from the northern alluvial aquifer. Monitoring wells in which water levels declined (fig. 12, well 1L-3) during the summer months typically were not adjacent to surface-water irrigation sources and were not in the northern alluvial aquifer.

\section{Interstate Canal}

Seepage of surface water from part of the Interstate Canal in the study area occurs during the transport of surface water from the diversion point to Lake Minatare (fig. 1) east of the study area. This seepage occurs as the hydraulic head in the canal builds up and eventually provides sufficient downw?rd force to push the water through the bed of the canal. Thus, the Interstate Canal loses some of its flow to the northern alluvial aquifer. Babcock and Visher (1951) estimated loss during transit at about 25 percent of the total flow.

Herrmann (1976) reported that substantial amounts of recharge to the alluvial aquifer in eastern Wyoming were introduced by seepage from the Interstate Canal and its laterals. In the study area, water-level data from monitoring wells showed that surface water seeps through the bottoms of the canals and into the aquifer. This is evident because the largest rises in ground-water levels (fig. 12, well 1A-3) directly followed the start of diversions into the caral. Water levels in monitoring wells farther away from the canals typically either did not rise as much as those near the canals or declined during the summer months when ground water is withdrawn for irrigation.

Evaluation of ground-water-level data in the study area indicates that water levels in monitoring wells near the canals rose about $9 \mathrm{ft}$ during the summer months (fig. 12, well 1A-3). Water levels in monitoring wells placed farther away from the canals did not rise more than about 2 to $3 \mathrm{ft}$ (fig. 12, well 1M-3). Statistical evaluation of water-level data using the Wilcoxon rank-sum test and based on distance from the canal indicates that water-level rises in monitoring wells within $1,000 \mathrm{ft}$ of the Interstate Canal 
were significantly greater $(\alpha=0.05, \mathrm{p}$-value $=0.0)$ during the course of the summer than water levels in monitoring wells farther than $1,000 \mathrm{ft}$ from the Interstate Canal.

\section{Tri-State Canal}

Water-level changes in monitoring wells near the Tri-State Canal did not indicate as much canal seepage as was indicated near the Interstate Canal. Water levels in monitoring wells immediately downgradient from the Tri-State Canal reacted like those downgradient from the Interstate Canal-they rose during the summer months when the canal was full and then declined when diversions ceased and the canal emptied. Most of the rises in water levels in monitoring wells near the Tri-State Canal probably can be attributed to movement of ground water from the northern alluvial aquifer into the southern alluvial aquifer and to seepage of surface water from the Tri-State Canal.

In September 1998, a potentiometer was used to measure hydraulic-head differences between the southern alluvial aquifer and the wetlands (site SW11). The measurements indicated that hydraulic head in the southern alluvial aquifer was $1.1 \mathrm{ft}$ greater than the hydraulic head in the wetlands (site SW11). Therefore, this difference suggests that an influx of water was moving into the southern alluvial aquifer. Because the differences in hydraulic head were so great, this influx probably originated from sources having much higher hydraulic heads - the northern alluvial aquifer and, possibly, the Tri-State Canal (when operating).

The large hydraulic head in the southern alluvial aquifer likely resulted from the large head gradient from the Tri-State Canal to the southern alluvial aquifer, from the northern alluvial aquifer to the southern alluvial aquifer, or a combination of both. Thus, an upward hydraulic gradient exists between the wetlands (site SW11) and the southern alluvial aquifer. It is likely that this upward hydraulic head created the wetlands-all of which occur near the break in slope of the ground-water table between the northern and southern alluvial aquifers - and are similar to the system described by Winter (1976) and Winter and others (1998).

Onsite inspections of the Dutch Flats area identified numerous springs and seeps along the bedrock high between the northern and southern alluvial aquifers just north of the Tri-State Canal. Discharge from springs and seeps in this area are dependent on surface-water flows in the canals that supply recharge to the ground-water system. Near Morrill and the wetlands site (SW11) during late winter months (about 5 months after the irrigation season), ground water was observed to seep into reaches of the Tri-State Canal that lie below the water table of the northern alluvial aquifer and higher than the water table of the southern alluvial aquifer. These observations were made when air temperatures were subfre ezing and ice quickly formed in low spots on the bed of the canal. Thus, during late winter, ground water likely moved from the northern alluvial aquifer through or over bedrock and discharged into the Tri-State Canal. When surface water was diverted into the Tri-State Canal during the irrigation season, surface water likely flowed through the bottom of the Tri-State Canal into the southern alluvial aquifer. It is likely that, at that time, ground water still flowed from the northern to the southern alluvial aquifer. However, it also is probable that ground-water flow was hindered somewhat when water was present in the Tri-State Canal.

\section{North Platte River}

The altitude of the North Platte River is lower than the altitude of any canals, which helps cause ground water derived from canal seepage to move toward the North Platte River. Most of the surface-water/groundwater interaction that occurs with the Ncth Platte River likely takes place in the hyporheic zone. The total depth of the hyporheic zone of the North Platte River is unknown but probably extends $r$ more than several feet.

Additional surface-water/ground-water interaction likely occurs as the result of bank storage when the North Platte River is at a high stage. During highstage conditions (fig. 6), surface water irfiltrates the banks of the river causing ground-water levels in the vicinity of the river to rise. After the stage of the North Platte River recedes, ground-water levels near the North Platte River decline when ground water flows back into the river.

\section{Chemical Interaction}

Recharge of ground water by water from the canals resulted in temporal variations in the quality of ground water in the study area. Time-series data were collected along transect $B-B^{\prime}$ and along a transect about $0.5 \mathrm{mi}$ west of $B-B^{\prime}$. Temporal changes in nitrate and uranium concentrations and UARs in 
response to streamflow at varying depths in ground water were examined. Other water-quality constituents, such as specific conductance and selected major ions, also were evaluated. The water-quality variables showing the largest differences in chemistry between surface and ground water were used as indicators of surface-water/ground-water interaction.

Temporal changes in the water quality of the Interstate Canal (site SW1) during the irrigation season were small (fig. 24). Along the North Platte River [North Platte River at the Wyoming-Nebraska State line (site SW2) and at Morrill (site SW9)], temporal changes in flow of the river caused temporal changes in water quality. The quality of water in the Tri-State Canal (site SW3) during the summer also changed similar to the changes observed in water from the North Platte River at the Wyoming-Nebraska State line (site SW2). Changes in the water quality of the North Platte River were seasonally dependent, with the larger differences in water quality measured during spring and winter and smaller changes measured during the irrigation season (fig. 24). The largest relative changes in surface-water quality were detected in uranium concentrations in samples from the North Platte River at Morrill (site SW9). Uranium concentrations in water collected from the North Platte River at Morrill decreased from $31 \mu \mathrm{g} / \mathrm{L}$ on February 17,1998 , to $15 \mu \mathrm{g} / \mathrm{L}$ on March 18, 1998. Smaller changes in nitrate concentrations were measured. Small variations in UARs were detected in water samples from the North Platte River (fig. 24). Differences in UARs have been used in other studies to determine sources of uranium (Snow and Spalding, 1994; Zielinski and others, 1997; Verstraeten and others, 2000).

\section{Interstate Canal}

The largest seasonal changes in the quality of the shallow ground water in the alluvial aquifer near the Interstate Canal occurred in response to seepage from
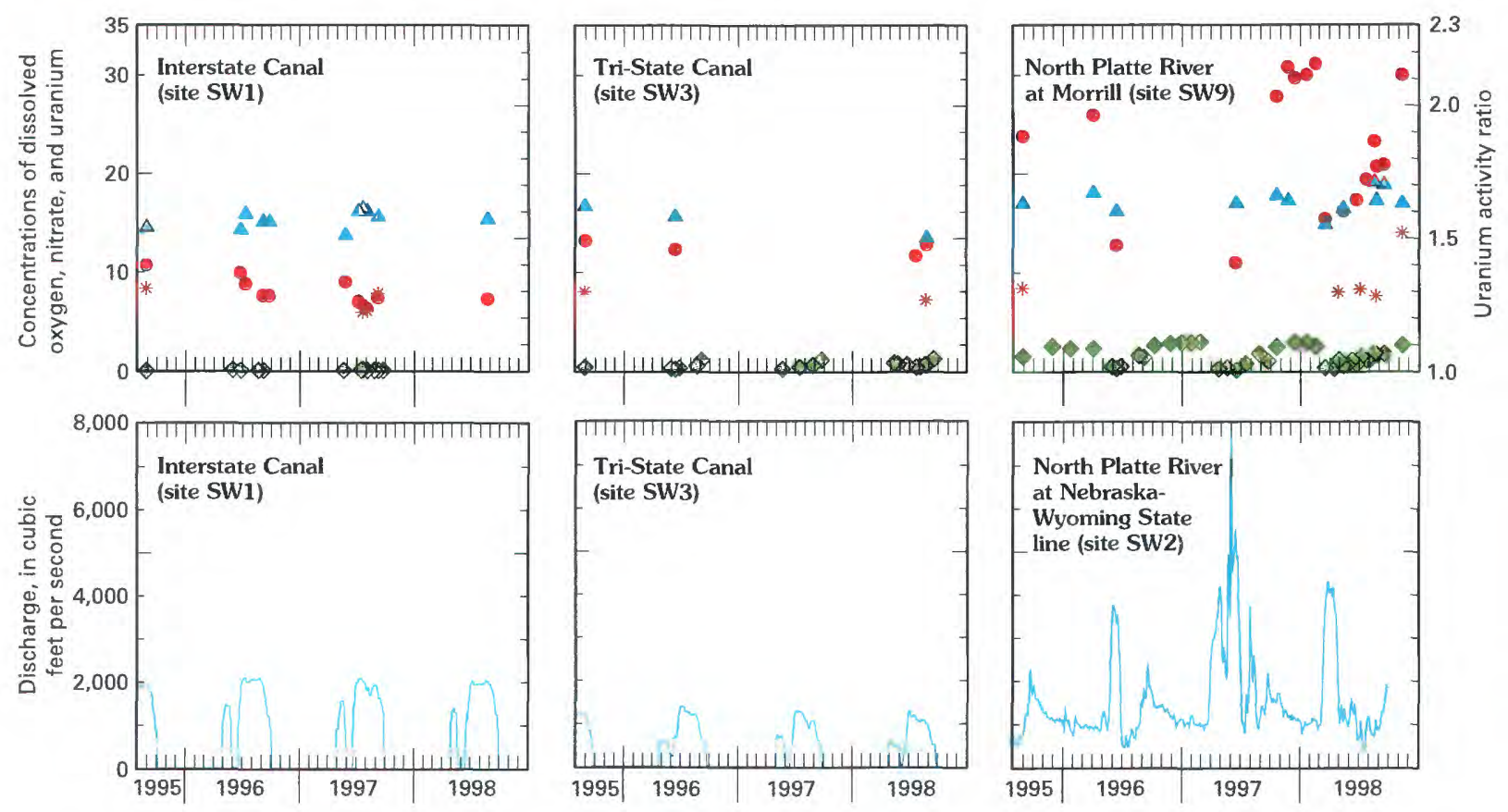

\section{EXPLANATION}

* Dissolved oxygen, in milligrams per liter

- Nitrate concentration, in milligrams per liter

- Uranium concentration, in micrograms per liter

^ Uranium activity ratio (right axis)

Figure 24. Comparison of trends in dissolved oxygen, nitrate, and uranium concentrations, and uranium activity ratios and discharge for Interstate Canal, Tri-State Canal, North Platte River at Morrill, and North Platte River at Wyoming-Nebraska State line, 1995 through 1998. Locations of sampling sites are shown in figure 1. 

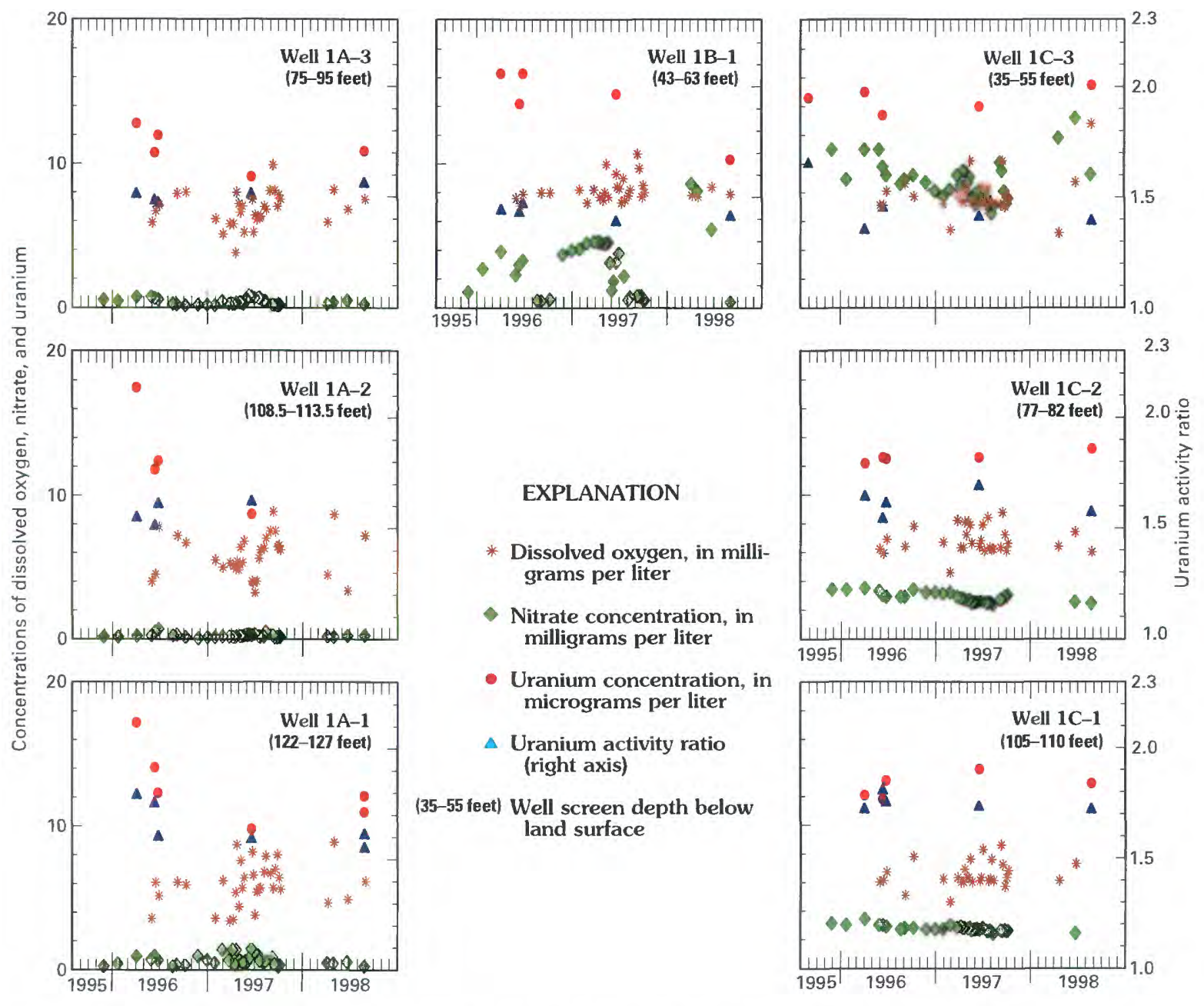

Figure 25. Comparison of trends in dissolved oxygen, nitrate, and uranium concentrations, and uranium activity ratios in water from nested wells 1A, 1B, and 1C, Dutch Flats area, 1995 through 1998. Locations of wells are shown in figure 8.

this canal (figs. 24-26). Nitrate concentrations in shallow ground water south of the Interstate Canal were larger (greater than $6 \mathrm{mg} / \mathrm{L}$, for example, in water from well $1 \mathrm{C}-3$, fig. 25) than in water from the Interstate Canal (site SW1) (generally less than $2 \mathrm{mg} / \mathrm{L}$, fig. 24) during the irrigation season. A few feet north of the Interstate Canal, beneath cultivated land, the shallow ground water ( 83 to $103 \mathrm{ft}$ below the land surface) contained more than $6.0 \mathrm{mg} / \mathrm{L}$ nitrate (fig. 26, water from well 2A-1). However, data from nested well 1A (fig. 25), beneath uncultivated land, indicated nitrate concentrations in ground water were less than $1.0 \mathrm{mg} / \mathrm{L}$ about $80 \mathrm{ft}$ south of the Interstate Canal at all depths ( 75 to $127 \mathrm{ft}$ below the land surface and less than $50 \mathrm{ft}$ below the water table) independent of time of year. Thus, nitrate concentrations near the canal were variable over short distances.
Nitrate concentrations in shallow ground water in the alluvial aquifer near the Interstate Canal decreased to levels similar to those in surface water during the irrigation season (water from wells $2 \mathrm{~B}-3$ and $2 \mathrm{~B}-2$ ). On the basis of this nitrate data, surface water appeared to replace shallow ground water completely within about 1 month. These changes were observed in the upper $30 \mathrm{ft}$ of the aquifer within about $1 \mathrm{mi}$ of the canal (figs. 25 and 26; water from wells 1B, 2B-1, and $2 \mathrm{C}$ ).

At distances less than 2 mi south of the Interstate Canal, where the water table is shallow (less than $40 \mathrm{ft}$ deep) (fig. 9), noticeable temporal changes in nitrate concentrations were detected during the irrigation season. These changes were in response to seepage and mixing of water from the Interstate Canal with local ground water and, in places, seepage from nearby 

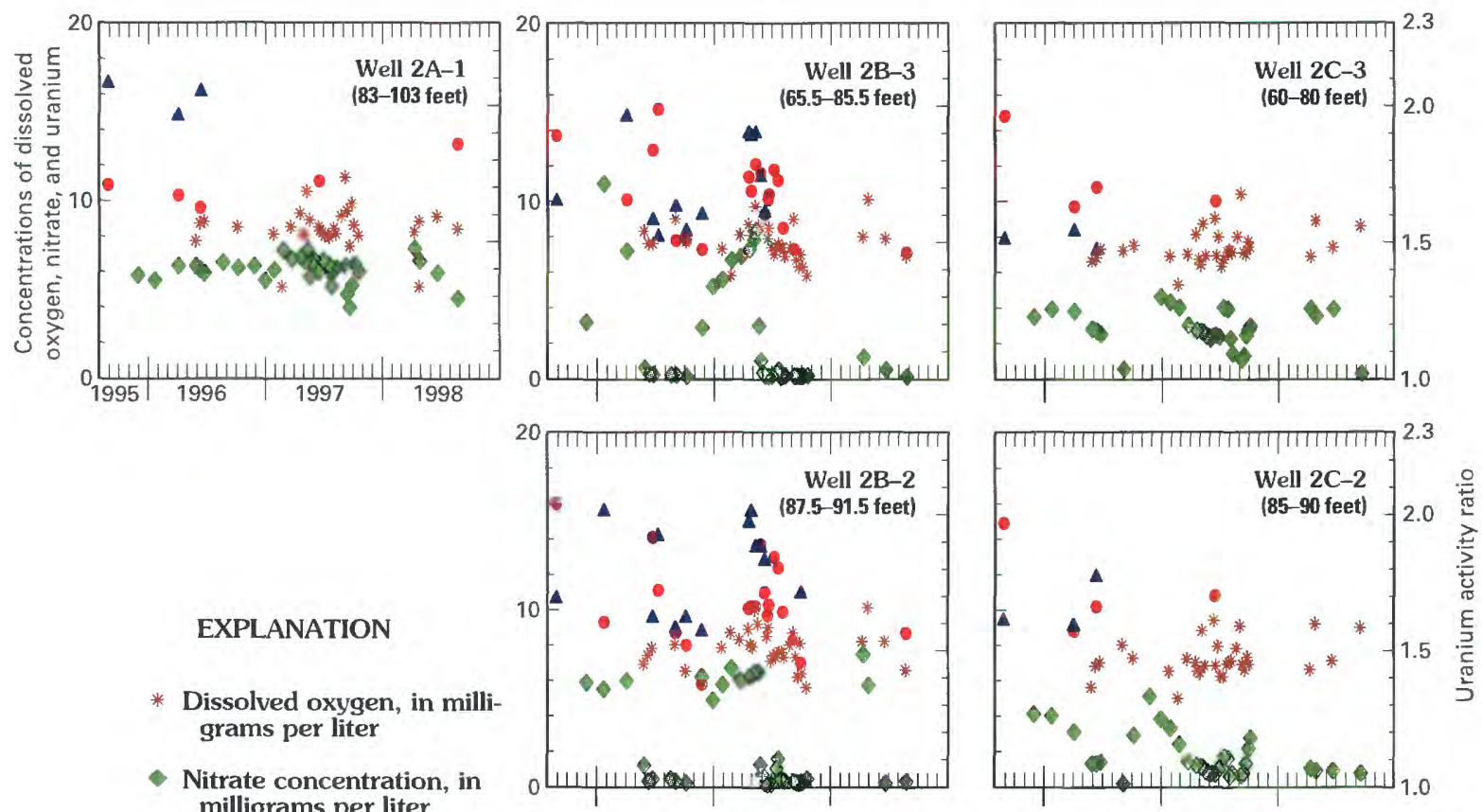

Nitrate concentration,
milligrams per liter

- Uranium concentration, in micrograms per liter

$\triangle$ Uranium activity ratio (right axis)

(85-90 feet) Well screen depth below land surface
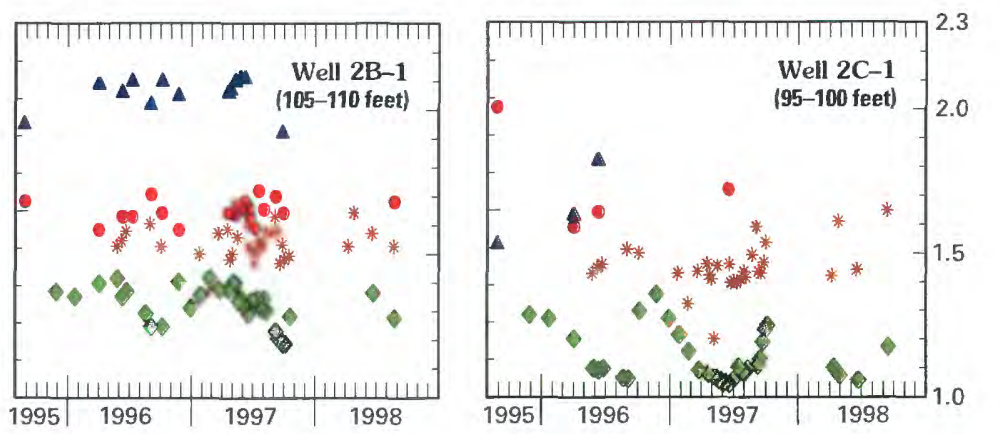

Figure 26. Trends in dissolved oxygen, nitrate, and uranium concentrations, and uranium activity ratios in water from well 2A-1 and nested wells 2B and 2C, Dutch Flats area, 1995 through 1998. Locations of wells are shown in figure 8.

laterals. These changes, however, were less obvious than closer to the canal and were detected mainly near the water table (fig. 25 , well $1 \mathrm{C}-3$ ) and in the proximity of laterals but not at depth (fig. 25, well 1C-1).

At distances greater than $2 \mathrm{mi}$ south of the Interstate Canal, decreasing nitrate concentrations as a consequence of seepage and mixing of surface water from the Interstate Canal or seepage from laterals were not as obvious. Instead, irrigation water, distributed onto the fields, may have aided in transporting nitrogen from the land surface through the unsaturated zone to the ground water, contributing to increases in nitrate concentrations in ground water (Verstraeten and others, 2000). Verstraeten and others (2000) suggested that a large part of the local ground water was derived from surface-water irrigation, on the basis of agedating information, nitrogen data, and data on isotopes of water (hydrogen and oxygen), nitrogen, and uranium.

In addition, at distances greater than $2 \mathrm{mi}$ south of the Interstate Canal and in the southern alluvial aquifer, large fluctuations in nitrate concentrations were detected in samples from wells completed at or near the water table (wells $1 \mathrm{~F}-1,1 \mathrm{H}-3,1 \mathrm{~J}-3,1 \mathrm{~L}-3$, $1 \mathrm{M}-3,2 \mathrm{~F}-2,2 \mathrm{~F}-3$, and $2 \mathrm{~J}-3$ (fig. 27). These changes in nitrate concentrations could have been associated with the large changes in water levels during the irrigation season, which affected the depth below the water table from which the samples were collected. Sampling at the same depth below land surface but at varying depths below the water table could result in apparent changes in nitrate concentrations over time because of the stratified nature of nitrate in ground water (figs. 15 and 16). 

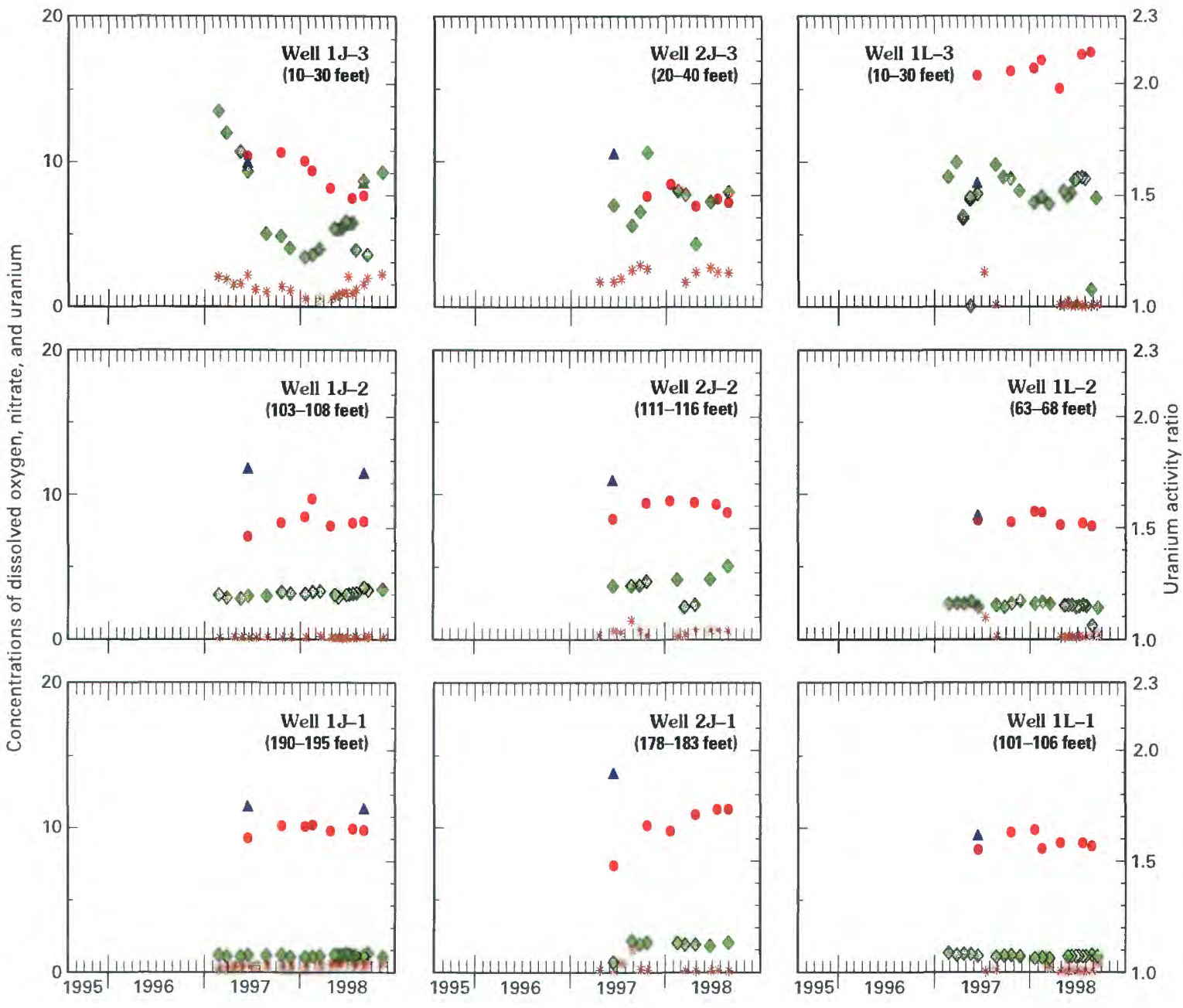

EXPLANATION

* Dissolved oxygen, in milligrams per liter

- Nitrate concentration, in milligrams per liter

- Uranium concentration, in micrograms per liter

$\triangle$ Uranium activity ratio (right axis)

(101-106 feet) Well screen depth below land surface

Figure 27. Trends in dissolved oxygen, nitrate, and uranium concentrations, and uranium activity ratios in water from nested wells $1 \mathrm{~J}, 2 \mathrm{~J}$, and 1L, Dutch Flats area, 1995 through 1998. Locations of wells are shown in figure 8.

Additional local indicators of surfacewater/ground-water interaction were specificconductance values and sulfate (fig. 28) and uranium concentrations and UARs (figs. 25 and 26), and calcium and magnesium concentrations (not shown). Specific-conductance values and sulfate concentrations were generally larger in water samples from the Interstate Canal than in those from the shallow ground water (fig. 28, well 2B). When water was flowing through the Interstate Canal, increases in specific conductance and sulfate concentrations in shallow ground water occurred. These increases in concentrations, however, were not as pronounced and rapid as the changes observed in nitrate concentrations near the Interstate Canal. Calcium and magnesium concentrations also were larger in water from the Interstate Canal than in water from the alluvial aquifer, resulting in similar changes in the local ground-water chemistry. 


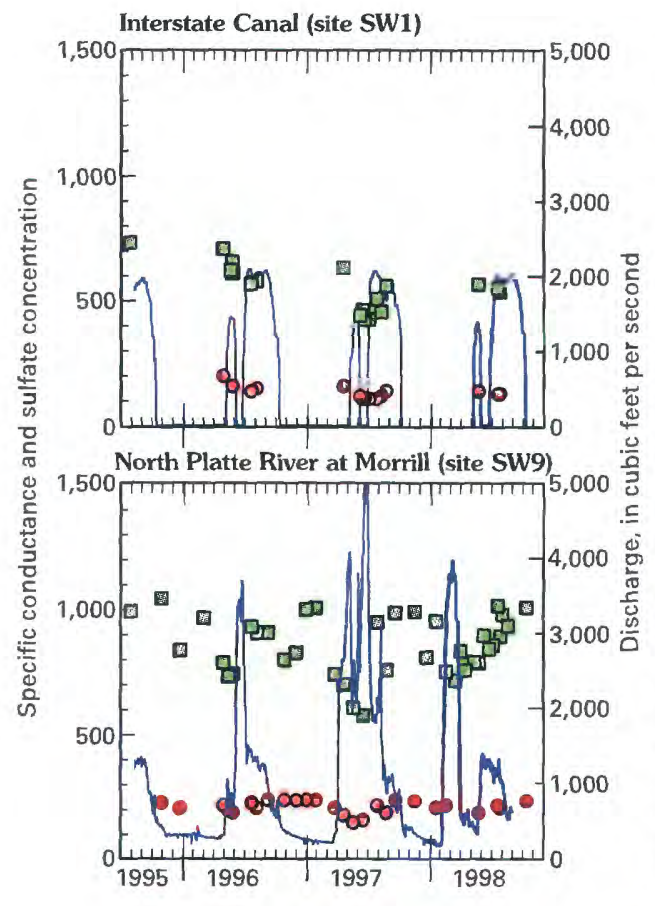

EXPLANATION

Discharge, in cubic feet per second

- Specific conductance, in microsiemens per centimeter at 25 degrees Celsius

- Sulfate, in millgrams per liter

(65.5-85.5 feet) Well screen depth below land surface
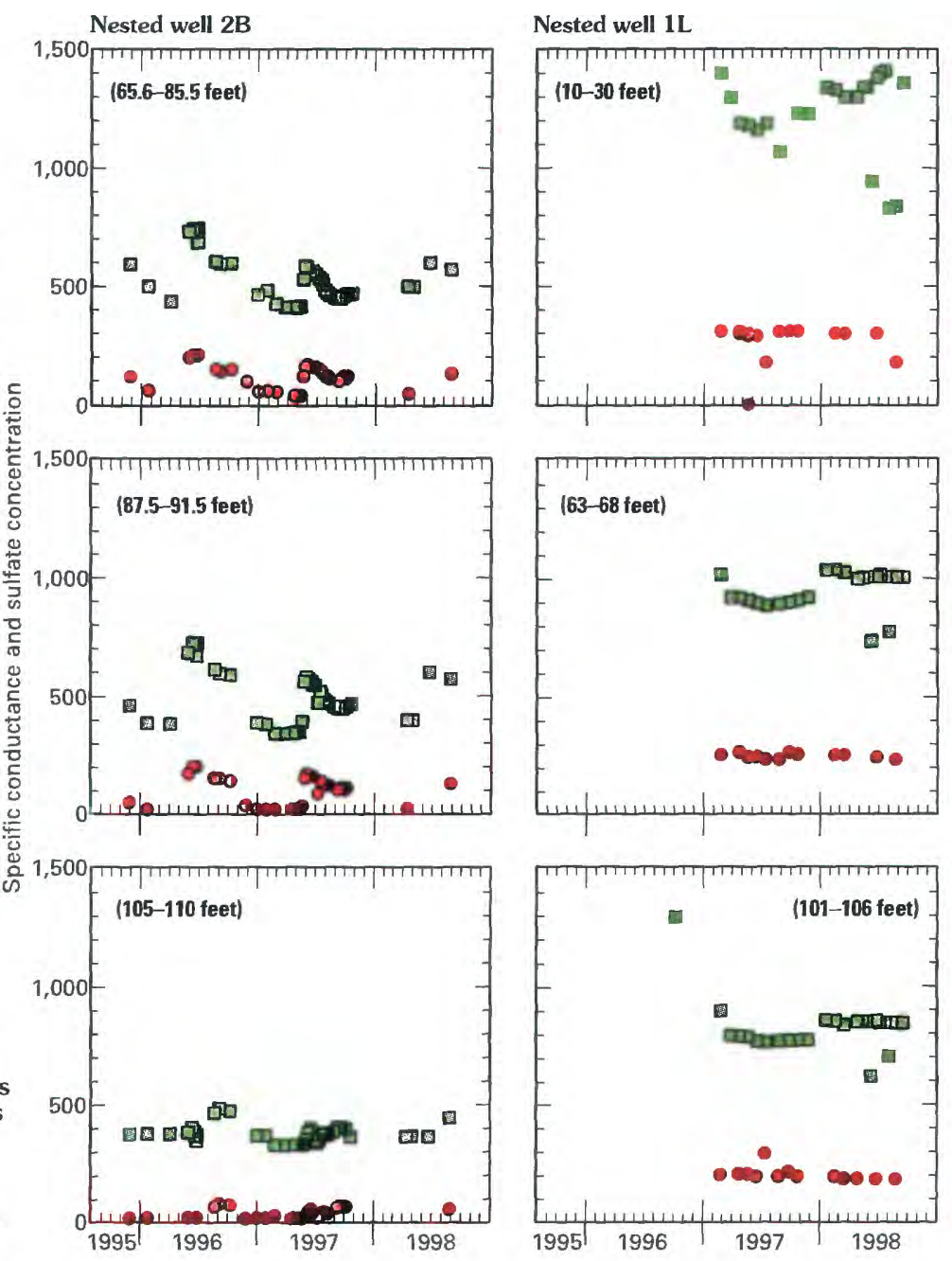

Figure 28. Trends in specific-conductance values and sulfate concentrations in water samples from Interstate Canal, North Platte River, and nested wells 2B and 1L, Dutch Flats area, 1995 through 1998. Locations of sampling sites are shown in figures 1 and 8.

Uranium concentrations in local shallow ground water $(10.0$ to $12.0 \mu \mathrm{g} / \mathrm{L})$ near the Interstate Canal decreased to concentrations of 6.0 to $8.0 \mu \mathrm{g} / \mathrm{L}$ when water from the Interstate Canal containing smaller uranium concentrations than the Interstate Canal $(6.0$ to $9.0 \mu \mathrm{g} / \mathrm{L}$ ) reached nested well $2 \mathrm{C}$ (figs. 24 and 26 ). On the basis of uranium concentrations in surface and ground water, mixing did not appear as significant at depth, which is probably a reflection of the different adsorptive-desorptive capacities of nitrate (a negative ion that is repelled by clay minerals) and uranium (uranium complexes that can adsorb to clay and organic matter) in solution. Similar changes in uranium and UARs were noted (fig. 26). Radon (not shown) did not show these temporal changes, even over short periods (days) and at shallow depth. The results indicate that radon is not a good indicator of surface-water/ground-water interaction in the Dutch Flats area, in part because of its short half-life and, therefore, short time available to establish new equilibria with the atmosphere, sediment, and ground water.

\section{Tri-State Canal and North Platte River}

Effects of surface-water chemistry on groundwater chemistry south of the Tri-State Canal and along the North Platte River were not as obvious as those near the Interstate Canal. A possible explanation of this difference could be that less seepage occurs from the Tri-State Canal than from the Interstate Canal because the flows in the Tri-State Canal tend to be about 60 percent of the flows in the Interstate Canal at their maximum flow rates (fig. 24). Another potential explanation is that the flow of water from the northern alluvial aquifer locally diminished the effect of 
Tri-State Canal water. In addition, substantial amounts of water from the Tri-State Canal may seep into the wetlands, as was discussed previously. Nitrate, uranium, and UAR data in samples from the wetlands site (SW11) are more similar to those found in the Tri-State Canal than to those of local ground water in the alluvial aquifer, either shallow or deep, suggesting that the largest component of water present at the wetlands site during the irrigation season was TriState Canal water.

Near the North Platte River, the water chemistry is different and more difficult to understand. The complexity of the water chemistry probably is associated partly with the wide range in flow conditions of the river. Generally, the river is gaining water and has base flows of about $400 \mathrm{ft}^{3} / \mathrm{s}$. During base-flow and near-base-flow conditions, river water probably originates in part from ground water. However, during spring peak flows, flooding sometimes occurs. At such times, surface water becomes bank storage.

As mentioned previously, the water quality of the North Platte River fluctuated over time (fig. 24). The quality of water from wells completed near the river (fig. 27, water from wells $1 \mathrm{~J}, 2 \mathrm{~J}$, and $1 \mathrm{~L}$ ) and the water table also fluctuated (fig. 12). Because the nested wells are more than $0.5 \mathrm{mi}$ from the river, it is difficult to establish a relation between temporary changes in surface-water and ground-water quality. More information on the interaction of surface and ground water could be obtained by constructing nested wells closer to the river and by collecting time-series data from nested wells $1 \mathrm{~K}-94$ and $26 \mathrm{~K}-94$. Uranium concentrations in the river during the winter tended to be large (more than $30 \mu \mathrm{g} / \mathrm{L}$ ) (fig. 24). The concentrations in shallow water near the river (water from wells $1 \mathrm{~J}, 2 \mathrm{~J}$, and $1 \mathrm{~L}$ ) generally also were large (more than $20 \mu \mathrm{g} / \mathrm{L}$ ) (fig. 27) throughout the year. Decreases in specific conductance, sulfate concentrations, and UARs in water from the North Platte River at Morrill were detected during snowmelt runoff in the spring and early summer compared to those observed during the winter. These changes were not observed in water from nested wells near the North Platte River.

During high stage, uranium concentrations in water from the North Platte River were less than during low stage (fig. 24). During low stage, the large uranium concentrations in water from the river probably are associated with ground-water sources as suggested by Snow and Spalding (1994). The data collected during this study support their conclusions (fig. 24). The large uranium concentrations in the shallow alluvial water from well $1 \mathrm{~L}-3$ are not well understood. Additional investigations are underway to determine the sources of uranium in the surface water and shallow ground water.

Near the North Platte River, shallow ground water characterized by large nitrate concentrations probably is diluted with river water characterized by small nitrogen concentrations during periods of high stage. Locally, reduction of nitrate to other species of nitrogen also is possible, especially when flooding occurs and anaerobic conditions may exist. Additional wells installed in closer proximity to the river may be able to provide more information on local interaction of surface and ground water. Nevertheless, the nitrate data support the interpretation that uranium in shallow ground water near the North Platte River is derived primarily from ground-water sources and not from the river.

\section{SUMMARY AND CONCLUSIONS}

A study of the water resources of the Dutch Flats area in western Nebraska was conducted from 1995 through 1999 to describe the surface water and hydrogeology, the spatial distribution of selected waterquality constituents in surface and ground water, and the surface-water/ground-water interaction in selected areas. As part of this effort, 11 surface-water sites and 79 ground-water sites were selected, water levels were measured, and 130 surface-water and 1,960 groundwater samples were collected for chemical analyses.

The predominant surface-water systems in the study area are the North Platte River and the Interstate and Tri-State Canals. The North Platte River is the source water for the Interstate, Tri-State, and Mitchell Canals, which irrigate about 43,200 acres in the study area. Discharge in the North Platte River system has been affected by human activities since the late 19 th century.

Aquifers in the study area include the alluvial aquifer and the Brule, Chadron, and Lance aquifers. The alluvial aquifer is unconfined, with saturated thicknesses ranging from less than 5 to more than $200 \mathrm{ft}$, hydraulic-conductivity values ranging from about 17 to $589 \mathrm{ft} / \mathrm{d}$, and specific yields from 0.17 to 0.32 . Most ground-water movement generally is toward the North Platte River. The North Platte River and the underlying alluvial aquifer are hydraulically connected. Recharge to the ground-water system by 
precipitation is much less than recharge to the groundwater system of the Dutch Flats area by infiltration of water seeping from irrigation canals and laterals and by infiltration of water applied for irrigation. Direct recharge of the ground-water system caused by infiltration of water seeping from the canals and laterals was reflected in water-level rises of as much as $9 \mathrm{ft}$ in monitoring wells adjacent to the canals. In areas where the Brule aquifer is near the land surface, depths to water vary from less than $5 \mathrm{ft}$ near the perennial drainages to 25 to $40 \mathrm{ft}$ near the Tri-State Canal. The Chadron aquifer is confined by a bentonitic mudstone and claystone of the Chadron confining unit. The depth to water in wells completed in the Chadron aquifer in the Dutch Flats area typically is 5 to $20 \mathrm{ft}$ below land surface. The Lance aquifer is confined, with depths to water in wells completed in this aquifer of about $15 \mathrm{ft}$ below the land surface, and generally is used only for stock and domestic supplies.

The specific conductance, calcium, magnesium, sulfate, silica, nitrate, uranium, and uranium activity ratios varied in space and with time and were used to evaluate surface-water/ground-water interaction and determination of ground-water flow. The specificconductance values in water from the Interstate Canal and ground water immediately upgradient from the canal were different. However, differences in specificconductance values between surface and ground water were not as obvious near the Tri-State Canal and were variable near the North Platte River. Major ions also varied between surface-water and ground-water sampling sites and along flow paths. Water from the northern alluvial aquifer generally moved from north to south and mixed in part with water from the Brule aquifer. In the southern alluvial aquifer south of the North Platte River, water moved from the southwest to the northeast and mixed in part with older water from the Chadron aquifer. An examination of major-ion chemistry contributed to a better understanding of the quality of water from tributaries and ground water. For example, water from the North Platte River at Morrill had an intermediate composition between ground water in the southern Brule aquifer and water in the Chadron and Lance aquifers.

In the Dutch Flats area, elevated nitrate concentrations are a concern in the ground water but not in surface water. The maximum nitrate concentrations in surface water were observed in samples from Akers Draw (11 mg/L) and Sheep Creek (7.6 mg/L), whereas water from the North Platte River at Morrill generally remained less than $3.0 \mathrm{mg} / \mathrm{L}$. In ground water, a stratification of nitrate was detected, with large nitrate concentrations at times exceeding $20 \mathrm{mg} / \mathrm{L}$ in shallow, young water and small nitrate concentrations (less than $0.05 \mathrm{mg} / \mathrm{L}$ ) in deep, old water. The median nitrate concentration in water from the alluvial aquifer was $4.3 \mathrm{mg} / \mathrm{L}$, and concentrations ranged from less than 0.05 to $24 \mathrm{mg} / \mathrm{L}$ during the summers of 1998 and 1999. The median nitrate concentration in water from the Brule aquifer was $5.0 \mathrm{mg} / \mathrm{L}$, and concentrations ranged from 0.23 to $11 \mathrm{mg} / \mathrm{L}$ during the summers of 1998 and 1999. The USEPA MCL of $10 \mathrm{mg} / \mathrm{L}$ was exceeded in 47 of 116 samples ( 15 percent) from all wells completed in the alluvial aquifer and in 11 of 48 samples ( 23 percent) collected from shallow wells completed in the alluvial aquifer. Nitrate generally was not present in shallow ground water near the water table, indicating that denitrification was not an important process in the alluvial aquifer. However, some evidence for denitrification may occur near the contact with bedrock.

Elevated uranium concentrations are a concern in both surface and ground water. Uranium concentrations ranged from 11 to $31 \mu \mathrm{g} / \mathrm{L}$ in water from the North Platte River at Morrill and were smaller in water from the North Platte River at the State line. The largest concentrations of uranium in surface water were detected in samples from Owl Creek near Lyman ( $c$ s much as $44 \mu \mathrm{g} / \mathrm{L}$ ). Smaller concentrations of uranium $(7.9 \mu \mathrm{g} / \mathrm{L})$ were detected in water from the Interstate Canal. Uranium concentrations in water from the alluvial aquifer ranged from about $2.0 \mu \mathrm{g} / \mathrm{L}$ in shallow ground water in the northern alluvial aquifer to as much as $80 \mu \mathrm{g} / \mathrm{L}$ in water from the southern alluvial aquifer. The median uranium concentration in water from the alluvial aquifer was $16 \mu \mathrm{g} / \mathrm{L}$. Seventeen c $f$ 121 samples collected from wells completed in the alluvial aquifer exceeded the USEPA MCL of $30 \mu \mathrm{g} / \mathrm{L}$ for uranium.

Radon activity mainly is a concern in water from the bedrock aquifers, including the Brule aquifer. Radon activity in surface water tends to be low because radon readily dissipates under atmospheric pressure. Ninety-four of 117 samples ( 80 percent) collected from wells completed in the alluvial aquifer rad radon concentrations that exceeded the proposed USEPA MCL of $300 \mathrm{pCi} / \mathrm{L}$. Concentrations in water from 15 of 16 wells completed in the Brule aquifer exceeded $300 \mathrm{pCi} / \mathrm{L}$. The largest radon activity was observed in ground water from well $1 \mathrm{~K}-94-1$ completed in the Chadron aquifer $(4,190 \mathrm{pCi} / \mathrm{L})$. 
Radon activity in excess of $1,000 \mathrm{pCi} / \mathrm{L}$ often was present in water from wells completed in the Brule aquifer. Uranium concentrations and radon activity indicate that water in the alluvial aquifer has been affected by water from the Brule, Chadron, and Lance aquifers.

In the study area, two prominent types of surfacewater features - one manmade and the other naturalcontrol surface-water/ground-water interaction. Two primary canals - the Interstate and Tri-State Canalscontribute substantial amounts of recharge to the alluvial aquifer, which generally discharges to the North Platte River. Surface water moving downward through the beds of the two canals affects the movement of ground water in the study area by increasing hydraulic heads in the underlying aquifer.

Surface-water/ground-water interaction was determined from water-level and water-quality data. Surface water diverted from the North Platte River into the canals seeped through the bottoms of the canals into the underlying aquifer, causing rises in groundwater levels. Most monitoring wells in the alluvial aquifer experienced water-level rises during the summer months. Ground-water levels declined when diversions ceased and canals were emptied. Ground water derived from canal seepage moved toward the North Platte River. Monitoring wells that experienced water-level declines in the summer months typically were not adjacent to surface-water irrigation sources and were not in the northern alluvial aquifer. Additional surface-water to ground-water interaction likely occurs as the result of bank storage when the North Platte River is at a high stage and surface water infiltrates the banks of the river, causing ground-water levels to rise in the vicinity of the river.

Recharge of ground water by surface water from the canals resulted in temporal changes in the quality of ground water in the study area. The most significant seasonal changes in the quality of the shallow ground water in the alluvial aquifer near the Interstate Canal occurred in response to seepage from the canal. Nitrate concentrations illustrated that surface water appeared to replace ground water in about 1 month in the upper $30 \mathrm{ft}$ of the alluvial aquifer within about $1 \mathrm{mi}$ of the canal. At distances less than $2 \mathrm{mi}$ south of the Interstate Canal, changes in ground-water chemistry were less obvious and were detected mainly near the water table and in the proximity of laterals. At distances greater than $2 \mathrm{mi}$, temporal declines of nitrate concentrations were not as obvious.

Additional local indicators of surface-water/ ground-water interaction were specific- conductance values, calcium, magnesium, sulfate, and uranium concentrations and uranium activity ratios. When water was flowing through the Interstate Canal, increases in specific conductance and sulfate were observed and decreases in nitrate and uranium concentrations, and uranium activity ratio in tha shallow ground water were observed. Effects of surface-water chemistry on ground-water chemistry south of the TriState Canal and along the North Platte Fiver were not as definitive. Water from the Tri-State Crnal appeared to have less effect on the local water quality, probably because smaller amounts of Tri-State Canal water were lost to the ground water. A relation between the temporary water-quality changes in surface and ground water near the North Platte River was difficult to determine because the nested wells are not on the bank of the river and are more than $0.5 \mathrm{mi}$ away from the river.

In summary, surface-water/ground-water interaction recharged the alluvial aquifer and improved the water quality locally near the canals anc' laterals through dilution of nitrate concentratiors in ground water with canal water near the canals and laterals. However, at great distances from the canals, irrigation with canal water transported nitrogen from the land surface to the ground water, and dilution with canal water at depth could not be established. The information gathered during this study provides local managers with the tools to improve the management of the quantity and quality of their water resources. This study also aids in strategic planning for future drinking-water supplies.

\section{SELECTED REFERENCES}

Alley, W.M., Reilly, T.E., and O.L. Franke, 1999, Sustainability of ground-water resources: U.S. Geological Survey Circular 1186, 79 p.

Babcock, H.M., and Visher, F.N., 1951, Grcund-water conditions in the Dutch Flats area, Scotts Pluff and Sioux Counties, Nebraska, with a section on Chemical quality of the ground water by W.H. Duran: U.S. Geological Survey Circular 126, $51 \mathrm{p}$.

Battaglin, W.A., and Goolsby, D.A., 1995, snatial data in geographic system format on agricultural use, land use, and cropping practices in the United States: U.S. Geological Survey Water-Resources Investigations Report 94-4176, 137 p.

Benham, B.L., 1998, Irrigating corn: University of Nebraska-Lincoln, G98-1354-A, accesed December 15, 2000, at URL: http://www.ianr.unl.edu/pubs/fieldcrop $₹ / g 1354 . h t m$ 
Boohar, J.A., 2000, Water resources data-Nebraskawater year 1999: U.S. Geological Survey Water-Data Report NE-99-1, $538 \mathrm{p}$.

Boohar, J.A., and Walczyk, V.C., 1997, Water resources data-Nebraska-water year 1996: U.S. Geological Survey Water-Data Report NE-96-1, 349 p. 1998, Water resources data-Nebraska-water year 1997: U.S. Geological Survey Water-Data Report NE-97-1, 462 p.

Burns, A.W., 1983, Hydrologic and morphologic changes in channels of the Platte River Basin in Colorado, Wyoming, and Nebraska - a historical perspective: U.S. Geological Survey Professional Paper 1277-G, 30 p.

Clerk of the Legislature, 1999, Nebraska blue book, 1998-99: Lincoln, Nebraska, p. 910-912.

Condra, G.E., and Reed, E.C., 1959, The geologic section of Nebraska, with a section on current revisions by E.C. Reed: Lincoln, Nebraska, Nebraska Geological Survey Bulletin 14A, $82 \mathrm{p}$.

Conservation and Survey Division, 1980a, Ground water nitrate-as-nitrogen concentrations-Scotts Bluff quadrangle: University of Nebraska-Lincoln, 1 sheet, scale $1: 250,000$.

$-1980 \mathrm{~b}$, Ground water nitrate-as-nitrogen concentrations-Alliance quadrangle: University of NebraskaLincoln, 1 sheet, scale 1:250,000.

Darton, N.H., 1903a, Geologic atlas of the United States, Scotts Bluff folio, Nebraska: U.S. Geological Survey Folio 88, 5 p.

1903b, Preliminary report on the geology and water resources of Nebraska west of the one-hundred and third meridian: U.S. Geological Survey Professional Paper 17, $69 \mathrm{p}$.

Dickinson, K.A., 1990, Uranium diagenesis in evaporite lacustrine mudstone of the Oligocene White River Group, Dawes County, Nebraska: U.S. Geological Survey Bulletin 1956, $16 \mathrm{p}$.

Druliner, A.D., Esmoil, B.J., and Spears, J.M., 1999, Field screening of water quality, bottom sediment, and biota associated with irrigation drainage in the North Platte Project Area, Nebraska and Wyoming, 1995: U.S. Geological Survey Water-Resources Investigations Report 98-4210, 43 p.

Durum, W.H., 1950, The chemical quality of the water, in Babcock, H.M., and Visher, F.N., 1951, Reconnaissance of the geology and ground-water resources of the Dutch Flats area, Scotts Bluff and Sioux Counties, Nebraska: U.S. Geological Survey Circular 126, p. 16-22.

Exner, M.E., and Spalding, R.F., 1994, N-15 identification of nonpoint sources of nitrate contamination beneath cropland in the Nebraska Panhandle - two case studies: Applied Geochemistry, v. 9, p. 73-81.

Freeze, R.A., 1969, The mechanism of natural ground-water recharge and discharge-1. One-dimensional, vertical, unsteady, unsaturated flow above a recharging or discharging ground-water flow system: Water Resou"ces Research, v. 5, p. 153-171.

Goodwin, R.G., and Diffendal, R.F., Jr., 1987, Paleohydrology of some Ogallala (Neogene) streams in the scuthern panhandle of Nebraska: The Society of Econc mic Paleontologists and Mineralogists Special Publicztion No. 39, p. 149-157.

Gormly, J.R., and Spalding, R.F., 1979, Sources and concentrations of nitrate as nitrogen in ground water $\mathrm{c}^{f}$ the Central Platte Region, Nebraska: Ground Water, v. 17, no. 3, p. 291-300.

Herrman, Raymond, 1976, Shallow aquifers relative to surface water, lower North Platte River Valley, Wyoning: Water Resources Bulletin, v. 12, no. 2, p. 371-380.

Hurr, R.T., 1981, Ground-water hydrology of the Crane Meadows wildlife area, near Grand Island, Hall County, Nebraska: U.S. Geological Survey Open-File Report 81-1109, 43 p.

Kircher, J.E., and Karlinger, M.R., 1983, Hydrologic and morphologic changes in channels of the Platte River Basin in Colorado, Wyoming, and Nebraska-a historical perspective: U.S. Geological Survey Professional Paper 1277-B, 49 p.

Langmuir, 1978, Uranium solution-mineral equilibria at low temperatures with application to sedimentary ore deposits: Geochimica Cosmochimica Acta, v. 42, p. $547-569$.

Lappala, E.G., Emery, P.A., and Otradovsky, F.J., 1979, Simulated changes in ground-water levels and streamflow resulting from future development (1970-2020) in the Platte River Basin, Nebraska: U.S. Geologi al Survey Water-Resources Investigations Report 79-26, $82 \mathrm{p}$.

Mathey, S.B., ed., 1990, Ground-water site inventory s.'stem, v. 2, chap. 4, in National water information system user's manual: U.S. Geological Survey Open-File Report 89-587, 288 p.

Maynard, J.B., 1983, Geochemistry of ore deposits: New York, Springer-Verlag, $305 \mathrm{p}$.

McMahon, P.B., Böhlke, J.K., and Bruce, B.W., 1999, Denitrification in marine shales in northeastern Colorado:

Water Resources Research, v. 35, no. 5, p. 1629-1642.

National Oceanic and Atmospheric Administration, 1974, Evaporation data retrieval, Nebraska: Asheville, North Carolina, U.S. National Climatic Data Center, accessed December 12, 2000, at URL:

http://nrcnt2.nrc.state.ne.us/cgi-win/evaption.exe 1998, Rainfall data retrieval, Nebraska: Asheville, North Carolina, U.S. National Climatic Data Center, accessed December 12, 2000, at URL: http://nrcnt2.nrc.state.ne.us/cgi-win/rainfall.exe 
Nebraska Department of Agriculture, 1998, Agricultural crop data: Lincoln, Nebraska, Agricultural Statistics Division, accessed December 12, 2000, at URL: http://nrcnt2.nrc.state.ne.us/cgi-win/crops.exe

Nebraska Department of Water Resources, 1998, Discharge records of streams, canals, pumps, and storage in reservoirs-hydrographic report: Lincoln, Nebraska, $218 \mathrm{p}$.

Nebraska Natural Resources Commission, 1994, Estimated water use in Nebraska, 1990: State Water Planning Review Process, 58 p.

Pritt, J.W., and Jones, B.E., eds., 1990, National water-quality services catalog: U.S. Geological Survey Open-File Report 89-386, 132 p.

Rainwater, F.H., 1956, Chemical quality of ground water, in Bradley, Edward, 1956, Reconnaissance of the geology and ground water in southern Sioux County, Nebraska: U.S. Geological Survey Open-File Report 89-386, $132 \mathrm{p}$.

Smith, F.A., and Souders, V.L., 1975, Ground-water geology of Banner County, Nebraska: Lincoln, Conservation and Survey Division, University of NebraskaLincoln, Nebraska Water Survey 39, 96 p.

Snow, D.D., and Spalding, R.F., 1994, Uranium isotopes in the Platte River drainage basin of the North American High Plains Region: Applied Geochemistry, v. 9, p. 271-278.

Sophocleous, M.A., Koussis, Antonis, Martin, J.L., and Perkins, S.P., 1995, Evaluation of simplified stream-aquifer depletion models for water rights administration: Ground Water, v. 33, no. 4, p. 579-588.

Souders, V.L., 1986, Geologic sections, ground-water maps, and logs of test holes, Morrill County, Nebraska: University of Nebraska Conservation and Survey Division, Open-File Report, 90 p.

State of Nebraska, 1998, Revised statutes of Nebraska: Lincoln, v. 3A, chap. 46, section 46-506.05(1) and (2), p. 1163.

Steele, E.K., 1988, Estimated use of water in Nebraska, 1985: Conservation and Survey Division, Institute of Agriculture and Natural Resources, University of Nebraska-Lincoln, Nebraska Water Survey Paper No. 64,125 p.

Steele, G.V., and Cannia, J.C., 1997, Reconnaissance of surface-water quality in the North Platte Natural Resources District, western Nebraska, 1993: U.S. Geological Survey Water-Resources Investigations Report 96-4316, 21 p.

Swinehart, J.B., and Diffendahl, R.F., Jr., 1997, Geologic map of the Scottsbluff $1^{\circ} \times 2^{\circ}$ quadrangle, Nebraska and Colorado: U.S. Geological Survey Miscellaneous Investigations Map I-12545, scale 1:250,000.

Swinehart, J.B., Souders, V.L., DeGraw, H.M, and Diffendal, R.F., Jr., 1985, Cenozoic paleogeography of western Nebraska, in Flores, R.M., and Kaplan, S.S., eds., Cenozoic paleogeography of west-central United States: Denver, Colorado, Rocky Mountain Section-
Society of Economic Paleontologists and Mineralogists, p. 213.

U.S. Environmental Protection Agency, 2000, Current drinking water standards-national primary and secondary drinking water regulations: Offi^e of Ground Water and Drinking Water, accessed Derember 27, 2000, at URL: http://www.epa.gov/safewater/ standards.html.

Verstraeten, I.M., Böhlke, J.K., and Kraemer, T.F., 2000, Ground-water/surface-water interaction : and sources of nitrogen, radon, and uranium in an irigated area: Liège, Belgium, International Conference on Tracers and Modeling in Hydrogeology, May 2000, International Association of Hydrological Sciences, p. 525-531.

Verstraeten, I.M., Carr, J.D., Steele, G.V., Thurman, E.M., Meyer, M.T., and Dormedy, D.F., 1999, Surfacewater/ground-water interaction-herbicide transport into municipal collector wells: Journal of Environmental Quality, v. 28, no. 5, p. 1396-1405.

Verstraeten, I.M., Sibray, S.S., Cannia, J.C., and Tanner, D.Q., 1995, Reconnaissance of ground-water quality in the North Platte Natural Resources Dist ict, western Nebraska, June-July 1991: U.S. Geolog̣ical Survey Water-Resources Investigations Report 94-4057, $114 \mathrm{p}$.

Verstraeten, I.M., Steele, G.V., Cannia, J.C., Böhlke, J.K., Kraemer, T.E., Wilson, K.E., and Carne', A.E., in press, Selected field and analytical metr ods and analytical results, Dutch Flats study area, w'estern Nebraska, 1995-99: U.S. Geological Su'vey Open-File Report 00-413.

Wells, F.C., Gibbons, W.J., and Dorsey, M.E., 1990, Guidelines for collected and field analysis of water-quality samples from streams in Texas: U.S. Geological Survey Open-File Report 90-127, 79 p.

Wenzel, L.K., Cady, R.C., and Waite, H.A., 1946, Geology and ground-water resources of Scotts Bluff County, Nebraska: U.S. Geological Survey Water-Supply Paper 943, $150 \mathrm{p}$.

Winter, T.C., 1976, Numerical simulation analysis of the interaction of lakes and ground water: U.S. Geological Survey Professional Paper 1001, 45 p.

Winter, T.C., Harvey, J.W., Franke, O.L., and Alley, W.M., 1998, Ground water and surface water--a single resource: U.S. Geological Survey Circular 1139, 79 p.

Yost, D.A., Brown, D.L., Buller, L.L., and $\mathrm{O}^{\prime}$ son, J.O., 1968, Soil survey, Scotts Bluff County, I'ebraska: U.S. Department of Agriculture, Soil Conser ration Service, $119 \mathrm{p}$.

Zielinski, R.A., Chafin, D.T., Banta, E.R., ant Szabo, B.J., 1997 , Use of ${ }^{234} \mathrm{U}$ and ${ }^{238} \mathrm{U}$ isotopes to evaluate contamination of near-surface groundwater with uraniummill effluents-a case study in south-central Colorado, U.S.A.: Environmental Geology, v. 32, no. 2, p. 124-136. 